Article

\title{
The Kupferschiefer Deposits and Prospects in SW Poland: Past, Present and Future
}

\author{
Sławomir Oszczepalski ${ }^{1}{ }^{*}$, Stanisław Speczik ${ }^{2}$, Krzysztof Zieliński ${ }^{2} \mathbb{D}$ and \\ Andrzej Chmielewski ${ }^{1}$ \\ 1 Polish Geological Institute-National Research Institute, 00-975 Warsaw, Poland; \\ andrzej.chmielewski@pgi.gov.pl \\ 2 Miedzi Copper Corporation, 00-807 Warsaw, Poland; sspeczik@miedzicopper.com (S.S.); \\ kzielinski@miedzicopper.com (K.Z.) \\ * Correspondence: slawomir.oszczepalski@pgi.gov.pl
}

Received: 14 August 2019; Accepted: 25 September 2019; Published: 28 September 2019

\begin{abstract}
Polish sediment-hosted stratiform copper deposits associated with Zechstein sediments are one of the country's most valuable natural resources and the basis for its copper industry. The paper presents the history of their research and current exploration. Although documented deposits and their identified resources are described and characterized, much attention is paid to areas located outside of them, including those where geological exploration is currently underway. The gradual depletion of shallow $\mathrm{Cu}-\mathrm{Ag}$ reserves in the Lubin-Sieroszowice district and elsewhere in the world requires exploration for deeper-seated deposits. To expand resources, time span and scale of copper production in Poland, exploration and definition of new prospects is of great importance. Thirty-five prospective areas with hypothetical and speculative resources have been delineated in SW Poland, including the most prospective areas adjacent to the $\mathrm{Cu}-\mathrm{Ag}$ Lubin-Sieroszowice deposit. The paper also focuses on those parts of the Fore-Sudetic Monocline where new copper deposits were recently identified. Their resources are described along with the methodology of establishing their boundaries, which differs from recommended Polish threshold parameters not taking into account the depths exceeding $1500 \mathrm{~m}$. Intelligent modern mining and ore processing technologies are considered as a prerequisite for future profitable development of deposits at deeper levels.
\end{abstract}

Keywords: $\mathrm{Cu}-\mathrm{Ag}$ deposits; Kupferschiefer; Rote Fäule; prospective areas; exploration; new deposits; SW Poland

\section{Introduction}

Recorded global resources of copper are estimated at $668.21 \mathrm{Gt}$ of ore at $0.45 \%$ of $\mathrm{Cu}$, containing $3035 \mathrm{Mt} \mathrm{Cu}$, including $130.01 \mathrm{Gt}$ of ore with a grade of $0.49 \% \mathrm{Cu}$, with mineral reserves in the amount of $641 \mathrm{Mt} \mathrm{Cu}$ [1]. Undeveloped identified resources planned for the future account for 2.1 billion tons of $\mathrm{Cu}$ [2-4]. Annual global mining is around $19.7 \mathrm{Mt} \mathrm{Cu}$ [4]. Forecasting shows that the world copper demand is expected to double through 2050, exceeding production. The mine production will peak in a narrow window of time, from 2031 to 2042, possibly in 2036 for copper and in 2030 for silver, and then begin to decline [5]. However, the full life cycle can be extended significantly due to the conversion of uneconomic resources into reserves [2,3].

The most important source of copper produced in the world in addition to porphyry copper deposits involves sediment-hosted stratiform copper deposits (SSC) [6-10]. These deposits are characterized by variable resources in the range of 1.6 to $170 \mathrm{Mt}$ (at $0.7-4.2 \% \mathrm{Cu}$ ), with a median of $14 \mathrm{Mt}$ of ore (at an average grade of $1.6 \% \mathrm{Cu}$ ) calculated for 170 deposits [11]. They occur mostly in the form of continuous or discontinuous ore bodies composed of sediments with a narrow stratigraphic 
range. One characteristic feature is the location within transgressive reduced rocks, mainly black shales (less frequently dark gray sandstones and carbonate rocks) occurring between red beds of continental origin and evaporites (Figure 1). For this reason, within the SSC type deposits, a "reduced-facies copper deposit subtype" or "the Kupferschiefer-type deposit" is distinguished [10]. For 50 deposits of this subtype, the median ore tonnage is $34 \mathrm{Mt}$ with a median grade of $1.5 \% \mathrm{Cu}$ [11]. Such deposits are the basis for the development of the Polish mining and copper industry. The discovery of the Lubin-Sieroszowice (L-S) deposit in 1957 [12] gave rise to further exploration for prospective areas elsewhere in SW Poland.

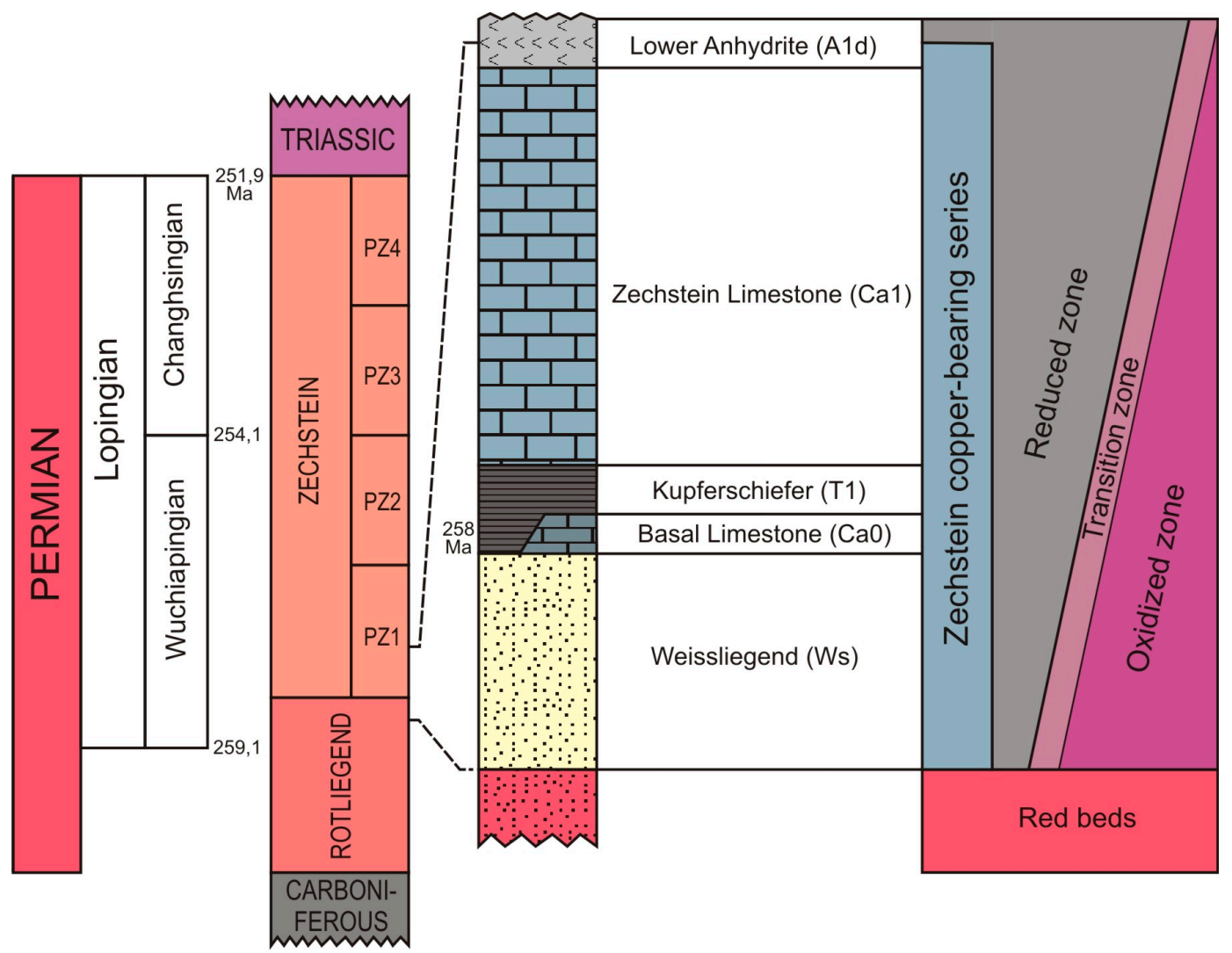

Figure 1. Stratigraphic position of the Zechstein copper-bearing series and distribution chart of geochemical zones that cut across the strata.

Petrological and geochemical studies of the Zechstein copper-bearing series indicated that the oxidation-reduction interface, both vertically and horizontally, is the boundary separating the oxidized Rote Fäule facies, barren in copper and silver, from reduced sediments with ore mineralization (Figure 1). Close relationship between the Rote Fäule areas and the orebodies indicated that determination of the ranges of oxidized zones is an extremely important exploration guide for the Kupferschiefer-type deposits [13-18]. Results of exploration drilling by the Polish Geological Institute-National Research Institute (PGI-NRI) and studies of cores from boreholes drilled by the Polish Oil and Gas Company (PGNiG) have been summarized in consecutive reports [18-23]. New studies of numerous drill cores strongly indicate that the Lower Zechstein rocks contain a very large volume of resources [24].

Considering the current state of knowledge and economic conditions, the resource base of Polish copper industry may be evaluated preferably when referring to the sediment-hosted stratiform $\mathrm{Cu}-\mathrm{Ag}$ deposits of the Fore-Sudetic Monocline. $\mathrm{Cu}-\mathrm{Ag}$ ores associated with the Kupferschiefer series are mined exclusively in the New Copper District (NCD) within the L-S deposit, operated by three underground mines: Lubin, Polkowice-Sieroszowice and Rudna. To the north of the developed deposits there are three undeveloped ones (Bytom Odrzański, Głogów and Retków). Identified resources per year in 2018 in the NCD amount to a total of $1802.562 \mathrm{Mt}$ of ore containing 32.62 Mt of Cu and $97.938 \mathrm{kt}$ of $\mathrm{Ag}$ 
including $1663.026 \mathrm{Mt}$ of ore (30.376 Mt of $\mathrm{Cu}, 86.853 \mathrm{kt}$ of $\mathrm{Ag}$ ) in developed deposits and 139,535 Mt of ore (2.244 Mt of $\mathrm{Cu}, 11.085 \mathrm{kt}$ of $\mathrm{Ag})$ in undeveloped deposits [25].

Deposits are mined by the underground room-and-pillar method at depths of between about $600 \mathrm{~m}$ and $1250 \mathrm{~m}$. Ore is processed by pulverizing and flotation, copper-silver concentrates are smelted in shaft and flash furnace smelters and refineries in Legnica and Głogów. Their production capacity amounts to $540 \mathrm{kt}$ of electrolytic copper and 1200 tons of silver a year. In 2018, KGHM Polska Miedź (KGHM), the sole producer of copper in Poland mined $30.252 \mathrm{Mt}$ of ore at $1.49 \% \mathrm{Cu}$ and $48.6 \mathrm{~g} / \mathrm{t}$ $\mathrm{Ag}$, comprising $452 \mathrm{kt}$ of $\mathrm{Cu}$ and 1471 tons of $\mathrm{Ag}$ [25]. In the same year KGHM recovered $501.8 \mathrm{kt}$ of electrolytic copper along with 1189 tons of $\mathrm{Ag}, 523 \mathrm{~kg}$ of Au, $27.21 \mathrm{kt}$ of $\mathrm{Pb}, 66.36$ tons of Se, $1.73 \mathrm{kt}$ of nickel sulfate, as well as sulfuric acid and copper sulfate. In addition, $2587 \mathrm{~kg}$ of $\mathrm{Au}, \mathrm{Pt}$ and $\mathrm{Pd}$ and 9.09 tons of Re were produced, both from own and foreign concentrates.

Currently, economic resources sustain an expected mine life of 50-60 years at a production rate of $30 \mathrm{Mt}$ ore per year. In order to extend long-term mining, the exploration and definition of new, deep seated reserves are of great importance. Since the demand for raw materials is continuously increasing, such systematic prospecting meets the reindustrialization trend of the EU, reflecting the importance of the mining industry for economic growth [26].

The aim of this paper is to characterize the prospective areas to determine the undiscovered resource base that meets specified minimum geological and economic criteria related to current mining and production practices, including those for grade, quality, thickness and depth. This study focuses on the exploration potential of prospective areas by comparison with the operated L-S deposits to establish the directions of further prospecting and research.

\section{History of Exploration and Mining}

Many papers have been written about the history of the Lubin-Sieroszowice deposit including numerous memoir publications (e.g., [12,27-30]. This shows the importance of the discovery, which can be considered the greatest geological discovery of the twentieth century in Europe.

In SW Poland, the earliest mineralogical examination of the Zechstein bearing series was in the Old Copper District (OCD) located in the North Sudetic Trough (Figure 2), where German geologists conducted exploration and appraisal studies in the area of Złotoryja (from 1914) and in the Grodziec region (from 1936). In 1936 the construction of the Lena mine started, and later it was decided to build two further mines (Konrad and Lubichów) [31]. Mining was discontinued as a result of the World War II.

Geological research in the Fore-Sudetic Monocline dates back to deep drilling in Krajkowo near Wrocław [32]. Next boreholes that penetrated the lower Zechstein units were drilled before the World War II near Wrocław: Pracze Odrzańskie (1938) and Muchobór Wielki (1939) with low-grade copper intersections of $0.08 \% \mathrm{Cu}$ [31]. Other drilling activities were carried out in the vicinity of Żagań, where Rotliegend and Zechstein sediments were found with evidences of oxidation but without significant copper concentration. Eisentraut [31] rightly recognized that the Zechstein profiles in the vicinity of the Wrocław region are connected to their counterparts in the North Sudetic Trough (Figure 2). It was suggested that those localities did not promise the existence of economic deposits north of the Variscan structures of the Sudetes [31]. Therefore, the area located north-west of Wrockaw was marked as insignificant for copper on the published maps [32-34].

The main problem that was faced after the World War II was the precise determination of the Fore-Sudetic Block, where the metamorphic rocks of the Fore-Sudetic Block contact Permian formations on the north-eastern side of the block, was fundamental for the commencement of exploration. For this purpose, the presumed occurrence of Zechstein sediments and the boundaries of the Fore-Sudetic Block [35] was reinterpreted first, and then in 1952-1953 the Bolesławiec-Głogów seismic profile was recorded, perpendicular to the border of this block (Figure 2).

According to the research project of Jan Wyżykowski, the Polish Geological Institute drilled the Gromadka IG 1 borehole (1955), where lower-Paleozoic metamorphic rocks of the Fore-Sudetic 
Block were found directly under Cenozoic units [19]. The next two boreholes, Ruszowice IG 1 (1955) and Gaiki IG 1 (1956), did not penetrate Lower Zechstein sediments as a result of a technical failure. Fortunately, the next borehole Sieroszowice IG 1 in 1957 hit the largest European copper ore deposit. The borehole revealed the presence of mineralization with a thickness of $1.96 \mathrm{~m}$ and an average $\mathrm{Cu}$ grade of $1.50 \%$ at the depth of $657 \mathrm{~m}$. Jedrzychówek IG 1 borehole determined the north-eastern border of Fore-Sudetic Block (Figure 2).

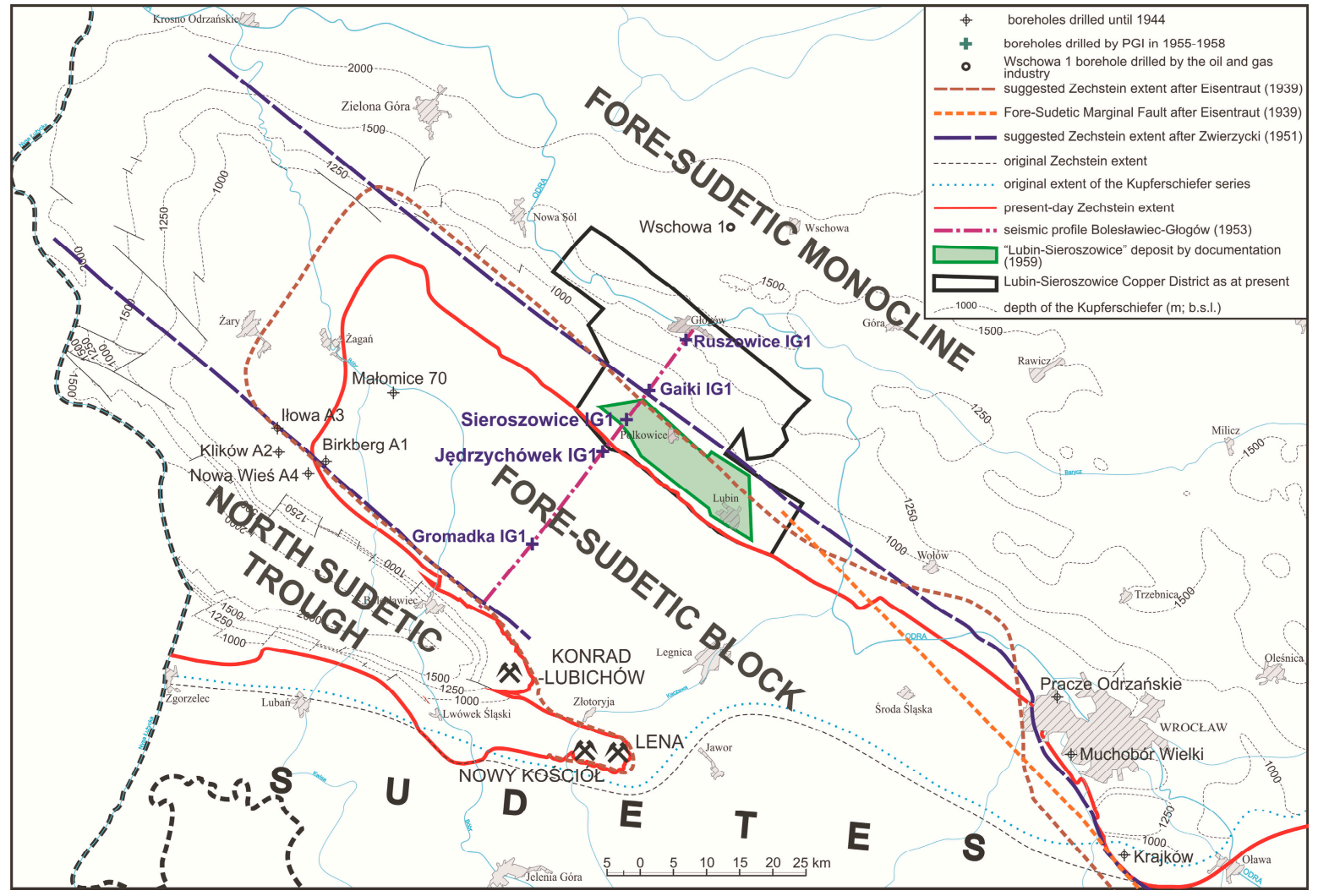

Figure 2. The scope of knowledge about geology and mineralization in SW Poland until 1951 and the first exploration results finalized with the discovery of the Lubin-Sieroszowice deposit in 1957. Modified after Oszczepalski [30].

Parallel to the exploration of copper ores conducted by the PGI-NRI, the oil and gas industry started its hydrocarbon exploration in the Fore-Sudetic Monocline drilling the Wschowa 1 borehole. In this borehole, located $13 \mathrm{~km}$ north-east of the present north-eastern border of the Lubin-Sieroszowice deposit, for the first time in the central part of the Fore-Sudetic Monocline, the Kupferschiefer horizon with poor copper mineralization was found at a depth of $1933 \mathrm{~m}$ [19].

In 1959, under the direction of Jan Wyżykowski, the Lubin-Sieroszowice deposit was drill-indicated based on the results from 24 boreholes, which proved the existence of a deposit at depths from 400 to $1000 \mathrm{~m}$, with indicated resources of $1364.65 \mathrm{Mt}$ of ore grading $1.42 \% \mathrm{Cu}$, with a thickness of $0.23-13.07 \mathrm{~m}$, containing $19.34 \mathrm{Mt}$ of copper and approx. $36 \mathrm{kt}$ of silver, in an area about $28 \mathrm{~km}$ long and $6 \mathrm{~km}$ wide, covering $175 \mathrm{~km}^{2}$. Copper mining in the NCD started in 1968 due to the commissioning of two mines: Lubin and Polkowice. A constantly increasing size of the L-S deposit resulted from further drilling [36,37]. A side effect of operations in the Fore-Sudetic Monocline was the discontinuation of mining activities in the North Sudetic Trough, in mines of the OCD (Nowy Kościół in 1967, Lena in 1973 and Konrad in 1989).

During 60 years of operation, the immense resources of the OCD and NCD have gradually diminished. In the OCD cumulative historical production amounts for $56.408 \mathrm{Mt}$ ore, including 14.468 Mt (1950-1973) in the Lena mine, 4.026 Mt in the Nowy Kościół mine (1954-1967) and 37.914 Mt 
(1953-1989) in the Konrad mine. In turn, in the mines of the NCD in years 1968-2018 KGHM mined $1.128 \mathrm{Gt}$ of ore containing $20.626 \mathrm{Mt} \mathrm{Cu}$ (Table 1) and over $40 \mathrm{kt} \mathrm{Ag}$. This means that in post-war history over $1.184 \mathrm{Gt}$ of ore have been mined in both these districts.

Table 1. Historical mine production in the New Copper District (Fore-Sudetic Monocline).

\begin{tabular}{|c|c|c|c|c|c|}
\hline Year & Production of Ore (Mt) & Cu Metal (kt) & Year & Production of Ore (Mt) & Cu Metal (kt) \\
\hline 1968 & 0.844 & 13.3 & 1994 & 23.743 & 423.0 \\
\hline 1969 & 2.194 & 35.4 & 1995 & 24.113 & 433.0 \\
\hline 1970 & 4.298 & 72.8 & 1996 & 25.988 & 473.0 \\
\hline 1971 & 6.544 & 110.3 & 1997 & 24.741 & 463.0 \\
\hline 1972 & 8.674 & 148.9 & 1998 & 26.087 & 488.0 \\
\hline 1973 & 9.835 & 175.6 & 1999 & 26.925 & 520.0 \\
\hline 1974 & 11.265 & 217.2 & 2000 & 27.142 & 513.0 \\
\hline 1975 & 14.537 & 268.7 & 2001 & 28.785 & 536.0 \\
\hline 1976 & 16.883 & 301.1 & 2002 & 28.480 & 572.0 \\
\hline 1977 & 18.463 & 331.1 & 2003 & 25.670 & 612.0 \\
\hline 1978 & 18.914 & 359.0 & 2004 & 26.124 & 626.0 \\
\hline 1979 & 20.504 & 377.0 & 2005 & 25.443 & 586.0 \\
\hline 1980 & 22.212 & 396.0 & 2006 & 25.903 & 553.0 \\
\hline 1981 & 18.450 & 340.0 & 2007 & 23.686 & 408.0 \\
\hline 1982 & 22.427 & 419.0 & 2008 & 22.750 & 474.0 \\
\hline 1983 & 24.301 & 464.0 & 2009 & 23.161 & 491.0 \\
\hline 1984 & 24.507 & 457.0 & 2010 & 22.448 & 472.0 \\
\hline 1985 & 24.681 & 457.0 & 2011 & 22.985 & 459.0 \\
\hline 1986 & 25.080 & 451.0 & 2012 & 30.182 & 479.0 \\
\hline 1987 & 25.183 & 457.0 & 2013 & 30.647 & 482.0 \\
\hline 1988 & 25.216 & 453.0 & 2014 & 31.023 & 473.0 \\
\hline 1989 & 26.219 & 398.0 & 2015 & 31.568 & 479.0 \\
\hline 1990 & 20.230 & 359.0 & 2016 & 31.984 & 480.0 \\
\hline 1991 & 19.403 & 350.0 & 2017 & 31.185 & 467.0 \\
\hline 1992 & 21.595 & 373.0 & 2018 & 30.252 & 452.0 \\
\hline 1993 & 24.629 & 428.0 & Total & 1128.103 & $20,626.4$ \\
\hline
\end{tabular}

Simultaneously with the documentation of copper ore deposits in the Fore-Sudetic Monocline, PGI-NRI conducted exploratory drilling in all prospective areas of Poland, also those exceeding depths of $1000 \mathrm{~m}[19,38]$. Exploration programs were supported by systematic research of available oil and gas drill cores, which resulted in a tremendous increase in data on the distribution of ore mineralization [13-15]. The most important exploration guide, the close spatial association of copper-silver orebodies with the Rote Fäule oxidized rocks, constituted a basis for the applied exploration strategy for copper ore deposits $[14,17,39,40]$. With the gradual inflow of information, the ranges of prospective areas and resource estimates became more precise in subsequent evaluations [18,20].

A significant increase in new data took place in the recent years [21] due to a detailed investigation of most of the available cores, which enabled the construction of maps with subsequent versions of oxidized and reduced areas allowing new assessments of resource prospects (Figure 3). Subsequent reports have specified the areal distribution of the Rote Fäule and prospective areas [22,23]. Recently Zientek et al. [41]) synthesized available information and estimated the location and quantity of undiscovered copper resources associated with the Kupferschiefer series. All data and large-scale metal zonation with respect to the oxidized rocks indicated that prospects adjacent to the oxidized areas represent the greatest potential. Among the demarcated prospects, the expected northwest-trending extension of the L-S deposit and the Sulmierzyce area seemed to be most interesting [42-45]. The increasing number of studied boreholes allowed Oszczepalski et al. [24] to present a summary with 38 prospective areas. Consequently, based on all studies of boreholes, extensive drilling operations were recently performed within several exploration concessions both on the Fore-Sudetic Monocline, in the North Sudetic Trough and in the Żary Pericline [30]. 


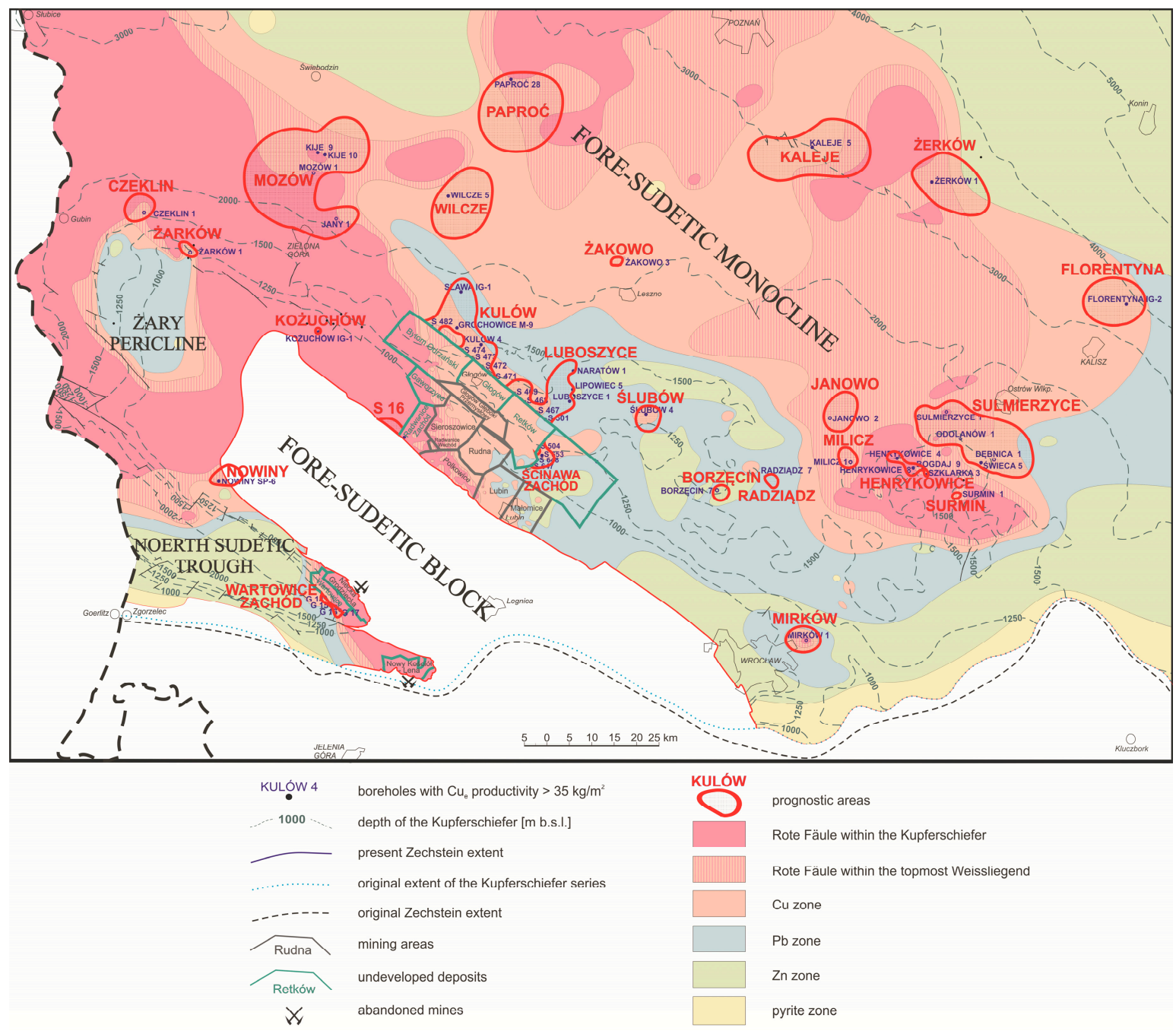

Figure 3. Map showing prospective copper areas in relation to Rote Fäule areas and metal zoning pattern in the Zechstein copper-bearing series of SW Poland completed in 2009. Modified after Oszczepalski and Speczik [21].

In the years 2011-2012, Miedzi Copper Corp.'s (MCC) companies initiated an extensive exploration program for deep copper and silver ore deposits in the Fore-Sudetic Monocline, in a north-western direction from the L-S deposit and in the eastern part of the Fore-Sudetic Monocline. First exploration boreholes confirmed the presence of $\mathrm{Cu}-\mathrm{Ag}$ orebodies in several localities on the Fore-Sudetic Monocline [46-48]. This exploration resulted in discoveries of deep copper and silver ore resources in several sites $[49,50]$. As the first step of prospecting work, MCC's strategy assumed the identification of geological structure and distribution of rock facies in an entire geological unit. Once the most appealing regions were demarcated, drilling operations were commenced in these so-called "sweet spots". Therefore, the project initially included 21 prospecting concessions with a total area of $11,547 \mathrm{~km}^{2}$. This methodology differs from the usual approach of mineral companies operating elsewhere, which targeted their exploration at already identified deposits, or their direct vicinity.

\section{Geological Background}

The Kupferschiefer copper deposits are located in the central part of the Fore-Sudetic Monocline and in the North Sudetic Trough and there are also numerous occurrences throughout SW Poland. These two areas are separated by the uplifted Fore-Sudetic basement block. The pre-Permian basement, composed of Early Paleozoic metamorphic rocks and Carboniferous clastics and granites, was folded 
and consolidated during the Late Carboniferous Variscan orogeny. The post-Variscan cover comprises Permian, Mesozoic and Cenozoic sediments [51]. The Permian and Mesozoic strata were probably deposited on the Fore-Sudetic Block, but were eroded during the Paleogene when movements uplifted the Fore-Sudetic Block.

The Polish Zechstein Basin forms a south-eastern extension of the Southern European Permian Basin [52-55]. As a result of the post-Variscan extensional tectonics, within the Variscan orogenic belt, depressions filled with Upper Carboniferous deposits were created and separated by NW-SE-trending ridges. The Szprotawa Ridge (currently a NW part of the Fore-Sudetic Block) was a paleo-high of the Variscan internides separating the Zielona Góra basin from the North Sudetic Trough basin. The Brandenburg-Wolsztyn-Pogorzela Ridge was a part of the Variscan externides that separated the Zielona Góra Basin from basins that existed in the Variscan Foreland area. During the Rotliegend period, paleo-depressions were partially filled with red beds up to $1000 \mathrm{~m}$ thick, represented by aeolian sandstones interbedded with deposits of alluvial fans, braided rivers and playas. In the western part of the studied region, at the beginning of the Permian lava and tuff (up to $1500 \mathrm{~m}$ thick) were erupted representing bimodal volcanism of basalt, trachybasalt, rhyodacite and rhyolitic rocks. The Rotliegend deposits are generally absent from the ridges.

Deposition in the Polish Zechstein Basin commenced with flooding of the continental Rotliegend basin as a result of rifting-induced subsidence combined with a contemporaneous rise in sea level [53]. The Zechstein Basin, about $1700 \mathrm{~km}$ long, extended from eastern England to western Lithuania, Estonia and Belarus. The transgression of the Zechstein Sea occurred in the Lopingian (Figure 1; [55,56]). As a result of transgression and cyclically progressing changes in the Zechstein Basin paleogeography, four basic cycles were deposited: Z1 (Werra), Z2 (Stassfurt), Z3 (Leine) and Z4 (Aller). Early Zechstein (the first and the second Zechstein cyclotems) is probably the equivalent of the upper Wuchaiaping (254.1-259.1 Ma), while the late Zechstein (the third and fourth Zechstein's cycloteme) corresponds to the Changhsing (251.9-254.1 Ma).

The $\mathrm{Cu}$-Ag deposits of SW Poland are associated with the Zechstein copper-bearing series, divided into the Weissliegend (Ws), the basal limestone (Ca0), the Kupferschiefer (T1) and the Zechstein Limestone (Ca1). The Weissliegend sandstone includes light gray sandstones, in the lower part of which there are aeolian sandstone and in the upper part, transgressive sandstones with numerous small sedimentary structures and bioturbations (locally with marine fauna), created due to redeposition of terrestrial sandstones. Its thickness may locally reach $40 \mathrm{~m}$. Conglomerates or breccias were formed near shores and paleo-elevations. On some paleo-elevations there are no sandstones and transgressive conglomerates. In the initial period of stable sea conditions, the nearshore basal limestone was formed, known as Mutterflöz (in Germany) or the Border Dolomite (in the L-S Copper District). Its thickness is usually insignificant; it reaches several dozen centimeters.

The Kupferschiefer represents the mature stage of transgression associated with the increase in the sea level. Its sedimentation took place under the reducing conditions of the stratified epicontinental sea [39]. The age of the Kupferschiefer is determined at $258 \mathrm{Ma}$ [56]. The Kupferschiefer has variable thickness, usually between 30 and $60 \mathrm{~cm}$. It generally overlies either the Zechstein Conglomerate or the Weissliegend sandstones and rarely the Rotliegend volcanics or pre-Permian rocks. It is absent from marginal parts of the Zechstein basin and from the elevated parts of ridges. It comprises laminated clay and mudstones composed of clay minerals (mainly illite with minor montmorillonite and kaolinite), carbonates (dolomite commonly prevails over calcite) and organic matter. Deep and shallow-water facies have been distinguished in the Kupferschiefer [39]. The deep water facies is characterized by its consistent thickness of $20-60 \mathrm{~cm}$ and is composed of alternating clay and carbonate laminae, with brighter laminae embedded in a dark matrix consisted of a mixture of clay and organic material. These sediments were formed at the sea bottom located below the base wave under anaerobic conditions. The shallow water facies in nearshore parts of the basin and around paleo-elevations is characterized by varied thickness (up to several m thick) consisting mostly of marls. 
The Kupferschiefer is overlain by the Zechstein Limestone deposited under oxygenated conditions. Its sequences are characterized by a regressive nature expressed by the presence of mudstones in the lower part of profiles as well as wackestones, packstones and bundstones in the upper part of profiles. The uppermost parts of profiles, depending on the paleogeographic position, are represented by supralitoral sediments. At the end of the Zechstein Limestone sedimentation on the coastal platform mainly wackestones and oncoidic and bioclastic packstones were formed as well as reefs up to $120 \mathrm{~m}$ in thickness developed on its slopes, made mainly of bryozoa-foraminifera packstones and boundstones. The basin area was composed mainly of oncolithic wackestones with columnar stromatolites. Locally, shallow-water oncolite packstones were formed in the intra-basin shoals forming condensed profiles less than $2 \mathrm{~m}$ in thickness. On the slopes of some paleo-elevations isolated bryozoa-foraminifera reefs with brachiopods and clams were also deposited. The Zechstein Limestone is followed by the Lower Anhydrite (A1d), Oldest Halite (Na1) and Upper Anhydrite (A1g). These rocks constitute the evaporative phase of the Zechstein Sea during the deposition of the first Zechstein cycle.

\section{Ore Controls and Guides to Exploration}

The types of ore correspond to lithological development: Sandstone, shale and carbonate rocks. The significant features of the mineralizing system have been described in numerous papers [16,17,39,40,57-64]. The following are of particular importance: (1) The limitation of oxidized areas and copper orebodies to the Variscan deformation zone; (2) the occurrence of oxidized Rote Fäule facies on the slopes of basement highs; (3) the presence of a transition zone between oxidized and reduced facies; (4) cross-cutting secondary oxidation of the reduced rocks, including especially the oxidation of organic material; (5) occurrences of sulfide mineralization over oxidized sediments and enrichments in gold and platinum in oxidized profiles; (6) the presence of the transitional zone with a width of 1 to $6 \mathrm{~km}$, in which there are both oxidized and reduced sediments with poor pyrite-chalcopyrite mineralization-in this zone, "relict areas" of reduced rocks within oxidized rocks and "oxidized areas" scattered within the reduced zone occur with common oxidation of the lowest part of the Kupferschiefer); (7) the restriction of high-grade $\mathrm{Cu}-\mathrm{Ag}$ mineralization to areas proximal to the so-called strong Rote Fäule and (8) the zonal distribution of metals and metal sulfides relative to the oxidized rocks. Characteristics of the geochemical zones are shown in Table 2. The cross-cutting relationships are presented in Figures 4 and 5 . These patterns, and in particular a close relationship between the Rote Fäule and orebodies, indicate that determination of the range of oxidized zones was considered an extremely important exploration guide to areas favorable for the $\mathrm{Cu}-\mathrm{Ag}$ Kupferschiefer-type deposits.

The richest mineralization is usually found in the upper part of the Weissliegend, in the basal limestone and the Kupferschiefer, as well as in the lower part of the Zechstein Limestone. The main ore minerals are $\mathrm{Cu}-\mathrm{S}$ minerals (chalcocite, digenite, covellite, djurleite and anilite), $\mathrm{Cu}$-Fe-S minerals (bornite, chalcopyrite and idaite) and Cu-As-Sb-S minerals (tennantite and tetrahedrite) [13,18,65-69]. Silver occurs in the form of its own minerals (native silver, electrum, stromeyerite, naumannite, mckinstryite, jalpaite, chlorotritite, eugenite and silver amalgams) but the most important silver carriers are base-metal sulfides - bornite (up to about $15 \% \mathrm{wt} \% \mathrm{Ag}$ ) and then chalcocite (up to $1.13 \mathrm{wt} \%$ ), tennantite and tetrahedrite (up to $2.4 \mathrm{wt} \%$ ), djurleite, digenite and chalcopyrite (up to $0.4 \mathrm{wt} \%$ ), galena (up to $0.3 \mathrm{wt} \%$ ), sphalerite (up to $0.1 \mathrm{wt} \%$ ) and pyrite (up to $1.5 \mathrm{wt} \%$ ) [65,70-73]. More recent studies have shown silver contents of up to almost $12 \mathrm{wt} . \%$ in chalcocite and up to $8.66 \mathrm{wt} . \%$ in bornite.

Oxidized rocks (Rote Fäule) were found in the basal limestone, the Kupferschiefer or the Zechstein Limestone above the oxidized Weissliegend in 33 oxidized areas [24]. In the central parts of the oxidized zone, the oxidation interval may locally reach even the lower part of the Lower Anhydrite (A1d) $[13,18,74,75]$. Outwards from the central parts of the oxidized areas the redox boundary cuts across the strata moving from the Lower Anhydrite to the lowermost part of the Weissliegend. The thickness of oxidized rocks is highly variable and ranges from several dozen meters (in the central parts of some oxidized areas) to several centimeters at distal areas. The greatest thickness of the 
oxidized shale-carbonate series $(15-30 \mathrm{~m})$ is recorded in the western part of the L-S mining area and locally in profiles with a significant thickness of the Zechstein Limestone developed in barrier facies (e.g., in the southern Żary Pericline). In oxidized rocks iron oxides (hematite, goethite) are dispersed throughout sediments or concentrated to form red spots, bands or earthy masses. They occur principally as submicroscopic red pigment, aggregates and spherules. Their shape, size and mode of occurrence strongly suggest that they are pseudomorphs after pyrite framboids. Oxidized sediments locally contain small amounts of sparsely dispersed sulfides (mostly pyrite, marcasite, chalcopyrite and covellite) with aureoles of red pigment. They are commonly enriched in $\mathrm{Au}, \mathrm{Pt}$ and $\mathrm{Pd}$ [22,42,76-81].

Extremely important for understanding the mineralization processes is the presence of the transition zone above the oxidized complex, defined initially by [17,59]. Its thickness varies from several millimeters in the Kupferschiefer horizon to several meters in the Weissliegend sandstone, the basal limestone (in the North Sudetic Trough) and the Zechstein Limestone. The upward transition of oxidized rocks into sulfide-containing reduced sediments is characterized by a gradual change from reddish-brown rocks through grey ones with red spots to dark-grey or black sediments. This change is accompanied by a distinct variability of various parameters (Table 2). One characteristic feature of this transition is the low-grade remnant mineralization represented by coexisting iron oxides (hematite and goethite), metal sulfides (covellite, pyrite, marcasite and minor chalcocite, bornite and chalcopyrite) and noble metals (native gold, Au-Ag alloys and Pd-arsenides).

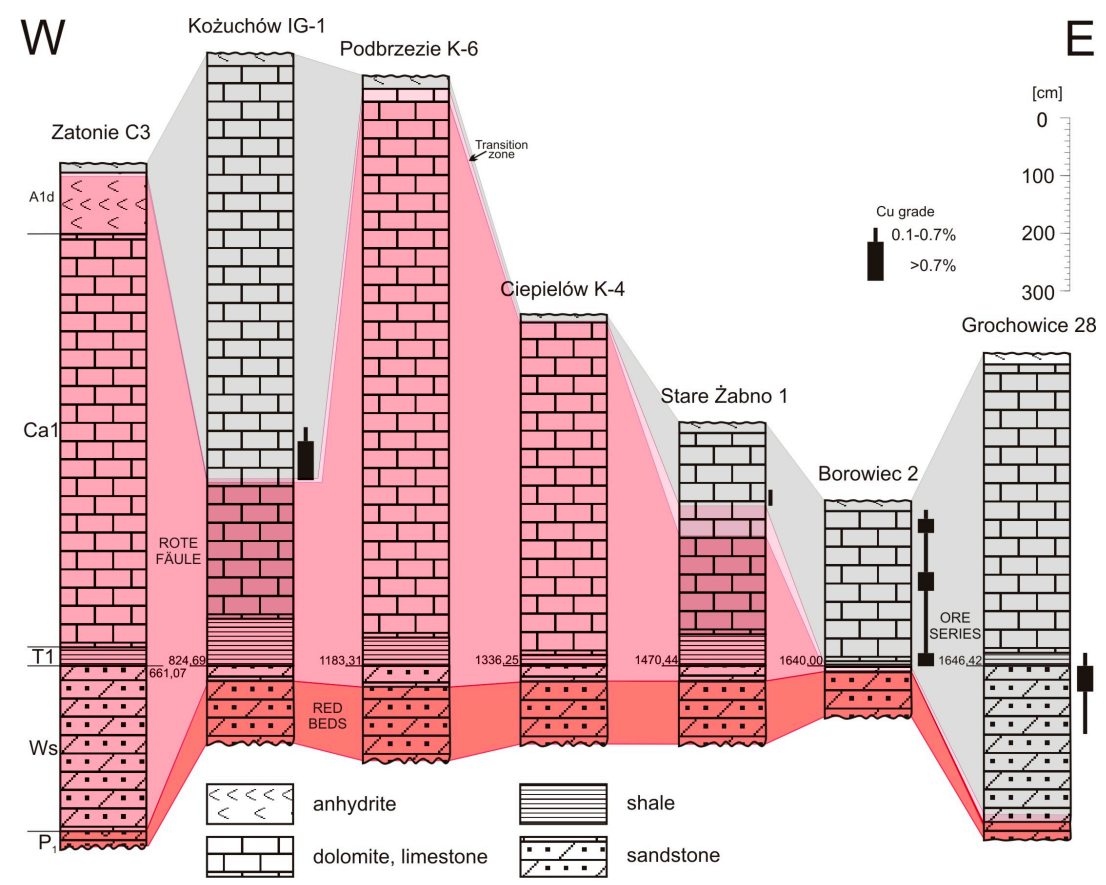

Figure 4. Correlation of selected profiles of the Zechstein copper-bearing series across the eastern part of the Zielona Góra Rote Fäule area. A1d-Lower Anhydrite; Ca1-Zechstein Limestone; T1-Kupferschiefer; Ws-Weissliegend; $\mathrm{P}_{1}$-Rotliegend.

Remnant sulfides occur mostly as finely scattered grains, rarely as mutual composites. Most remarkable are partial or total replacements of $\mathrm{Cu}$ sulfides by hematite and goethite $[14,17,39,59]$. $\mathrm{Cu}$ sulfides and pyrite grains are commonly corroded, invaded, veined and rimmed by iron oxides and only remnants are retained as minute grains dispersed in red-pigmented rocks [40,74,82-84]. Locally, hematite forms intergrowths with digenite or myrmekitic lamellae in bornite [85]. Covellinization of copper sulfides is common. Intergrowths and inclusions of native gold have been found in hematite [76]. Locally (e.g., in the North Sudetic Trough) sulfide aureoles around red spots and inclusions of bornite and chalcopyrite within the red spots have been identified. 


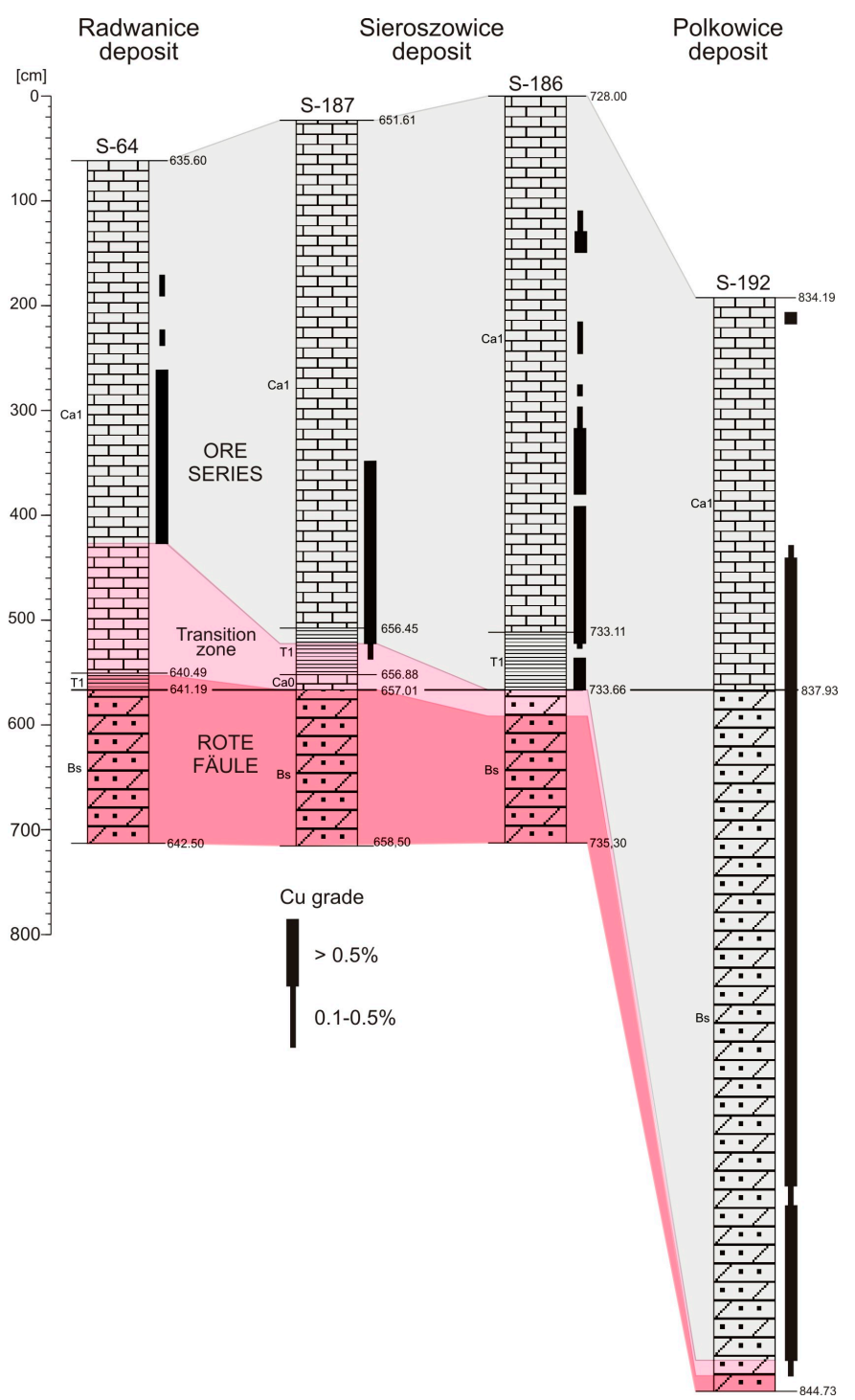

Figure 5. Correlation of selected profiles of the Zechstein copper-bearing series across the SW part of the Lubin-Sieroszowice deposit (for legend see Figure 4).

The metals are zoned both vertically and horizontally in a sequence of: $\mathrm{Fe}^{3+}(\mathrm{Au}, \mathrm{Pt}$, $\mathrm{Pd})-\mathrm{Cu}(\mathrm{Ag})-\mathrm{Pb}-\mathrm{Zn}-\mathrm{Fe}^{2+}$ in distinct zones around oxidized areas and the typical paragenetic sequence includes hematite (goethite)-covellite-chalcocite-bornite-chalcopyrite-galena-sphalerite-pyrite in which hematite postdates sulfides, $\mathrm{Cu}$-S-type sulfides are younger than $\mathrm{Cu}$-Fe-S-type sulfides and framboidal pyrite is the earliest (Figure 6). Locally, the Cu-Fe-S system is accompanied by Cu-As-Sb-S sulfides, galena, sphalerite and pyrite $[18,36,68-70,85,86]$. Although the ore mineral zonation pattern is observed as being complex on a mine scale $[65,68,69]$, it is clearly defined on a regional scale [18]. In areas with the highest copper concentrations, chalcocite, digenite and covellite predominate over the other sulfides whereas in areas further from the Rote Fäule area bornite, chalcopyrite, galena and sphalerite successively prevail. Farther away from oxidized areas, high- and low-grade mineralization is represented by a bornite-chalcopyrite assemblage with minor digenite, chalcocite, galena, sphalerite and pyrite. In distal areas, low-grade polymetallic ore mineralization is predominated by a chalcopyrite-galena-sphalerite association commonly accompanied by numerous pyrite and marcasite grains. 
Table 2. Characteristics of the Kupferschiefer from the oxidized, transition and reduced zones in SW Poland (compiled after [17,40,42,45,57-63]); EOM-extracted bitumen; HC-hydrocarbons, PAH-polycyclic aromatic hydrocarbons, Fla-fluorantene, Py-pyrene, Chr-chrysene, $\mathrm{Ph}$ - phenantrene; $\mathrm{MPh}$-methylphenantrenes; $\mathrm{HI}$-hydrogen index (mg HC/g TOC); $\mathrm{OI}-$ oxygen index (mg CO $2 / \mathrm{g}$ TOC); TOC—-total organic carbon.

\begin{tabular}{|c|c|c|c|}
\hline \multirow{2}{*}{ Diagnostic Features } & Oxidized Zone & Transition Zone & \multirow{2}{*}{$\begin{array}{c}\text { Reduced Zone } \\
\text { Cu-Ag Zone }\end{array}$} \\
\hline & \multicolumn{2}{|c|}{ Au-Pt-Pd Zone } & \\
\hline Color & Red & Gray-red & Black \\
\hline Hematite & Abundant & Present & Absent \\
\hline Hematite pseudomorphoses after & Present & Abundant & Absent \\
\hline Cu sulfides & Relicts & Minor & Abundant \\
\hline $\mathrm{S}_{\text {tot }}(\%)$ & $<0.1$ & $0.1-0.2$ & $0.9-6.0$ \\
\hline $\mathrm{Au}, \mathrm{Pt}, \mathrm{Pd}$ & Present & Enriched & Minor \\
\hline $\mathrm{MgO} / \mathrm{CaO}$ & Low & & High \\
\hline $\mathrm{K}_{2} \mathrm{O} / \mathrm{Na}_{2} \mathrm{O}$ & \multicolumn{2}{|c|}{ High } & Low \\
\hline TOC (\%) & $<0.5$ & $0.3-3.5$ & $2-17$ \\
\hline $\mathrm{Fe}_{2} \mathrm{O}_{3} / \mathrm{TOC}$ & $>5$ & $>0.7$ & $<0.7$ \\
\hline $\operatorname{EOM}(\%)$ & \multicolumn{2}{|c|}{$0.01-0.1$} & $0.02-0.2$ \\
\hline Saturated HC/aromatic HC & \multicolumn{2}{|c|}{$<0.4$} & $>0.4$ \\
\hline Heterocompounds (\% EOM) & \multicolumn{2}{|c|}{$<5$} & $>5$ \\
\hline Asphaltenes (\% EOM) & \multicolumn{2}{|c|}{$>60$} & $<60$ \\
\hline n-alkanes (ppm) & \multicolumn{2}{|c|}{$<0.5$} & $>1.0$ \\
\hline Isoprenoids (ppm) & \multicolumn{2}{|c|}{$<0.1$} & $>0.1$ \\
\hline Porphyrins (mg/100 g of rock) & \multicolumn{2}{|c|}{$<0.01$} & $0.01-0.1$ \\
\hline PAH (ppm) & $<2$ & $1-4$ & $0.5-3$ \\
\hline $\mathrm{Fla}+\mathrm{Py}+\mathrm{Chr}(\% \mathrm{PAH})$ & $>70$ & $50-70$ & $<50$ \\
\hline Dibenzotiophene (\% PAH) & $<10$ & $10-20$ & $10-15$ \\
\hline $\mathrm{Ph} / \mathrm{MPh}$ & $<2$ & $2-13$ & $<1$ \\
\hline Alginite & \multicolumn{2}{|c|}{ Absent } & Present \\
\hline Sapropel matrix & Low & Medium & High \\
\hline Bituminite & Low & High & Medium \\
\hline Vitrinite-like bituminite & \multicolumn{2}{|c|}{ High } & Absent \\
\hline Solid bitumen & \multicolumn{2}{|c|}{ High } & Low \\
\hline Vitrinite & Low & Medium & High \\
\hline Vitrinite reflectance $\left(\% \mathrm{R}_{\mathrm{o}}\right)$ & $>1.0$ & $0.7-1.2$ & $0.7-0.9$ \\
\hline HI (mg HC/g TOC) & \multicolumn{2}{|c|}{$<50$} & $>150$ \\
\hline $\mathrm{OI}(\mathrm{mg} \mathrm{CO} 2 / \mathrm{g}$ TOC) & $>50$ & $>20$ & $<20$ \\
\hline $\mathrm{T}_{\max }\left({ }^{\circ} \mathrm{C}\right)$ & \multicolumn{2}{|c|}{$>440$} & $<440$ \\
\hline $\mathrm{U}, \mathrm{Hg}$ & \multicolumn{2}{|c|}{ Low } & High (locally) \\
\hline $\mathrm{Se}$ & \multicolumn{2}{|c|}{ High } & Low \\
\hline REE & \multirow{2}{*}{\multicolumn{2}{|c|}{ High content }} & Low content \\
\hline $\mathrm{V} / \mathrm{Cr}$ & & & $4-16$ \\
\hline$\delta^{34} S_{\text {sulfide }}$ & \multicolumn{2}{|c|}{-34 to -15} & -42 to -33 \\
\hline$\delta^{34} S_{\text {sulfates }}$ & \multicolumn{2}{|c|}{5 to 6} & -25 to 8 \\
\hline$\delta^{13} C_{\text {ker }}$ & \multicolumn{2}{|c|}{ Negative } & Very negative \\
\hline$\delta^{13} C_{\text {carb }}$ & \multicolumn{2}{|c|}{-0.9 to 0.9} & 0.9 to 3.5 \\
\hline
\end{tabular}

In the early stages of studying the mineralization of the Kupferschiefer deposits, a view of their syngenetic origin prevailed. The breakthrough in determining the genesis of mineralization in Zechstein deposits was a result of documenting the close relationship between the occurrence of $\mathrm{Cu}-\mathrm{Ag}$ ores and oxidized areas. Early publications on this subject already indicated the existence of this obvious relationship but initially the syngenetic-early diagenetic mechanism of sulfide mineralization formation was preferred due to the tabular form of deposits, abundance of fine-grained dispersed ores and their attachment to the reduced facies. Over time, as a result of the recognition of secondary oxidation of the earliest formed copper sulfides the new view prevailed that the main stage of mineralization occurred during early-to-late diagenesis $[14,15,17,39]$. Detailed studies of this zones showed that there were transformation processes of an overlapping nature, manifested by the presence of numerous replacements of pyrite and copper sulfides by hydrothermal hematite [59]. The occurrence of hematite pseudomorphs after framboidal pyrite on the oxidized side of the redox front and pseudomorphs of copper sulfides after syndiagenetic framboidal pyrite in reduced areas became evidence of pyrite 
overprinting by copper mineralization [40]. It has been shown that sulfide mineralization always occurs above oxidized rocks. Such position of copper mineralization in the profile and lateral overlapping of oxidized and reduced facies resulted from an upward and lateral flow of fluids that caused the expansion of the hematitic alteration front overlapping of ores by hematitization, redistribution of metals and the location of $\mathrm{Cu}$-Ag orebodies directly above and around oxidized areas [17,39,61-64,87-90].

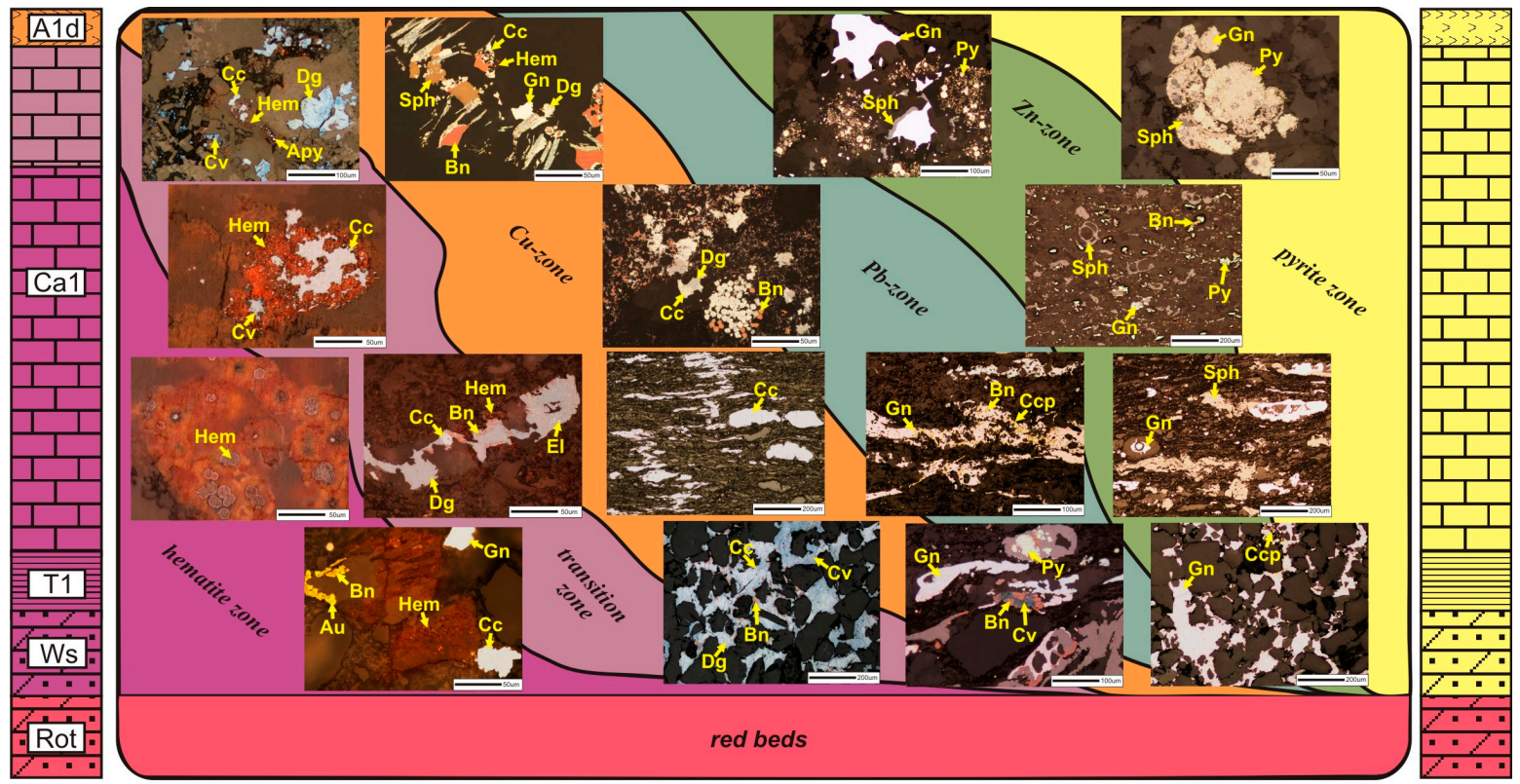

Figure 6. Schematic cross-section through the Zechstein copper-bearing series showing the distribution of ore minerals in metallic zones relative to the front of oxidation. Au-native gold, Apy-arsenopyrite, Bn-bornite, Cc-chalcocite, Ccp-chalcopyrite, $\mathrm{Cv}$-covellite, Dg-digenite, El—electrum, Gn—galena, Hem—hematite, Py—pyrite, Sph—sphalerite.

Oxidation of the initially reducing Kupferschiefer shales led to the destruction and leaching of unstable components, leaving behind only refractory and immobile organic constituents that survived during formation of the Rote Fäule/ore system. The zonation of organics, vitrinite reflectance and oxide/sulfide mineralization in relation to the oxidation front may be genetically linked to the intensity of ascendant circulation and interaction of mineralizing fluids with reduced sediments. The altering fluids caused depletion of kerogen in hydrogen equivalents, the aromatization of bitumen and the removal of saturated hydrocarbons from the liptinites and their lipid-rich precursors (Table 2). The residual organic matter within the Rote Fäule/ore system shows low frequency levels of alginite, bituminite and autochthonous vitrinite, a high relative proportion of vitrinite-like bituminite and solid bitumen, and displays very high reflectance of the non-recycled vitrinite. This oxidized organic matter is also characterized by low amounts of $\mathrm{C}_{\text {org }}$, bitumen, hydrocarbons, saturated hydrocarbons, n-alkanes, isoprenoids, porphyrins and steranes, high concentrations of phenantrenes, heavy aromatic hydrocarbons, asphaltenes, resins and tricyclic terpanes and high values of OI and $\mathrm{T}_{\text {max }}$ indices $[42,43,57,58,60-63,91,92]$. The oxidized shales have the lowest $\delta^{13} \mathrm{C}$ and $\delta^{18} \mathrm{O}$ values from carbonates and the highest $\delta^{34} \mathrm{~S}$ values from disseminated sulfides and $\delta^{13} \mathrm{C}$ values from kerogen $[58,63,92]$.

The telescopic nature of the mineralizing system and large-scale zonation pattern indicates that oxidized areas represent a central conduit for the mineralizing solutions. Therefore, it is obvious that the main volume of ore mineralization resulted from advanced passage of oxidizing, metalliferous chloride brines through the anoxic sediments of the basal Zechstein tectonic evolution of the Permo-Triassic basin $[39,64,87,93]$. The location of ore bodies above slopes of highs that are separated by depressions filled with Rotliegend sediments (red beds) are indicative of the fact that these sediments were the 
essential ultimate source for mineralizing solutions that flowed along the flanks of paleohighs from the Rotliegend aquifer. The mineralizing solutions were chloride brines with a maximum temperature of $135^{\circ} \mathrm{C}$, as indicated by the paleotemperatures of indigenous vitrinite and other thermal maturity indicators $[42,43,57,60,63]$. Hematite emplacement overprinted early copper minerals as evidenced by the nature of the transition zone. Base and noble metals were extensively redistributed due to the different level of leaching by spreading fluids. As a result, noble metals are concentrated in the oxidized rocks, whereas base metals are concentrated at the reduced side of the redox front. It seems plausible that the processes leading to the formation of the Kupferschiefer ore patterns were long-lasting and multiphase, continuing for tens of million years after the deposition of the Kupferschiefer dated at $258 \mathrm{Ma}[56]$.

The late-diagenetic age of mineralization is evidenced by dating. According to Jowett [87], convective flow of ore fluids is considered to be generated due to renewed extensional rifting during the Triassic. The dilatant veins and paleomagnetic age of hematite (250-220 Ma) indirectly suggest the Triassic age of $\mathrm{Cu}-\mathrm{Ag}$ deposits surrounding oxidized areas [88]. This age was corrected to a range of 255-245 Ma (Late Permian-Early Triassic) [94]. In turn, K-Ar dating of the neogenic illite abundant in both oxidized and reduced facies in the Kupferschiefer indirectly indicate a Triassic-Early Jurassic age (216-190 Ma) of mineralization [95]. Re-Os studies confirmed the late-Triassic age of $217 \pm 2$ Ma of chalcopyrite from the mine in Lubin and $212 \pm 7 \mathrm{Ma}$ for copper ore from Lubin-Polkowice [96].

The joint action of fluid flows related to compaction of the Permian basin and brine circulation caused by the geothermal field [89] was possible, as were the recirculation of mineralizing solutions [93] and their inflow via faults formed during seismic movements due to Permian-Triassic intra-continental rifting [97]. Quantitative mass balance evaluation implies that superposition of early- and late-diagenetic mineralization must have occurred in order to account for the observed Kupferschiefer mineralization in SW Poland [93]. The origin was also referred to as being of a multi-stage and long-term origin [9,66,98-100]. On the other hand, Borg et al. [101] argued that the Kupferschiefer mineralization was formed within a time span from Late Jurassic to Mid-Cretaceous, as a result of major crustal rearrangement with the break-up of Pangea based on the recent paleomagnetic dating of mineralization age in the Sangerhausen region (ages of 149 and/or $53 \mathrm{Ma}$; [102]).

\section{Assessment Process}

In 1990, a data base was established at the PGI-NRI, collecting the results of chemical analyses of continuous samples taken from drill cores, both from documented deposits and from prospective areas. This database was systematically supplemented with new results. There are currently results from more than 1700 deep boreholes including 619 holes from the Lubin-Sieroszowice deposit and 17 holes and mine profiles from the Nowy Kościół, Niecka Grodziecka and Wartowice deposits. Other boreholes were drilled in the entire Polish part of the Permian Basin, but most of them are situated in SW Poland. Until 2011 the cut-off criteria defined by the Regulation of the Minister of the Environment issued on 20 June 2005 were obligatory for the examination and evaluation of mineralization and the formal definition of the mineral inventory (Table 3). These parameters constituted the basis for documenting identified resources, including measured, indicated and inferred $\mathrm{Cu}$ and $\mathrm{Ag}$ resources. Currently, based on the Regulation of the Minister of the Environment dated 15 July 2015, the following threshold values of new parameters defining a mineral deposit and its boundaries are in use (Table 3).

Using standard processing software, the thickness of ore intervals was computed along with average concentration and copper productivity (surface density of $\mathrm{Cu}$ ) in the ore series. The productivity was calculated using the formula: $\mathrm{Q}=\mathrm{T} \times \mathrm{P} \times \mathrm{C} \times 10$, where: $\mathrm{Q}$-copper productivity $\left(\mathrm{kg} / \mathrm{m}^{2}\right)$ in a sampled sequence with metal concentration $\geq 0.5 \% \mathrm{Cu}$ plus $\mathrm{Ag}$ equivalent; $\mathrm{T}$-thickness of the mineralized sequence (m); $\mathrm{P}$ - weighted $\mathrm{Cu}$ equivalent grade $(\%)$ and $\mathrm{C}$-bulk density of mineralized rocks $\left(\mathrm{t} / \mathrm{m}^{3}\right)$. The following values of bulk density were used: 2.3 for sandstones, 2.5 for dolomites and limestones and 2.6 for shales. 
Table 3. Cut-off criteria (2005) and new parameters defining sediment-hosted stratabound copper deposits and their boundaries (2015).

\begin{tabular}{|c|c|c|c|}
\hline Parameter & Unit & Threshold (2005) & New Parameters (2015) \\
\hline Maximum depth of the ore deposit & $\mathrm{m}$ & $1250(1500)^{1}$ & 1500 \\
\hline $\begin{array}{l}\text { Sample cut-off } \mathrm{Cu} \text { grade delineating the } \\
\text { ore deposit }\end{array}$ & $\%$ & 0.7 & 0.5 \\
\hline $\begin{array}{l}\text { Minimum } \mathrm{Cu} \text { equivalent grade in } \\
\text { composite sample. Cu equivalent is } \\
\text { calculated from the formula } \mathrm{Cu}_{\mathrm{e}}=(\% \\
\mathrm{Cu})+0.01(\mathrm{~g} / \mathrm{t} \mathrm{Ag})\end{array}$ & $\%$ & 0.7 & 0.5 \\
\hline $\begin{array}{c}\text { Minimum } \mathrm{Cu} \text { equivalent productivity } \\
\text { of the ore deposit }\left(\mathrm{Cu}_{\mathrm{e}}\right)\end{array}$ & $\mathrm{kg} / \mathrm{m}^{2}$ & $50(35)^{2}$ & 35 \\
\hline
\end{tabular}

${ }^{1}$ The depth of $1500 \mathrm{~m}$ allowed for subeconomic resources. ${ }^{2}$ Value for subeconomic resources.

The use of quantitative data allows for quantitative assessment of undiscovered resources. The assessment focuses on delineation of prospective areas on the basis of chemical and mineralogical examination of core samples from PGI-NRI's and PGNiG's boreholes. The basis for determining boundaries of prospective areas of stratabound mineralization was the application of the new parameters (Table 3). Ignoring the maximum depth of $1500 \mathrm{~m}$, it was assumed that a productivity value of $\mathrm{Cu}_{\mathrm{e}}$ $35 \mathrm{~kg} / \mathrm{m}^{2}$ (or $\mathrm{Cu}$ in the absence of Ag analyses) determines the boundaries of prospective areas. Due to the lack of Ag results, in some boreholes only copper productivity was calculated, which in such cases means underestimated copper and silver resources for the given areas.

Cores of 370 archival boreholes were studied outside mining districts [18]. Through additional research of 280 more drill holes we have gathered a substantial volume of valuable exploration data for the construction of quantitative maps. As a result, 15 prospects with total hypothetical resources amounting to $70 \mathrm{Mt} \mathrm{Cu}$ at a depth up to $2000 \mathrm{~m}$ were delineated throughout the Sudetic Foreland [21]. Those prospects indicate a potential for the discovery of large deposits. Almost all of them were granted as exploration concessions to several domestic and foreign companies, which were pursuing these concessions [30].

These prospective areas can be differentiated into three groups based on their location relative to documented copper deposits and the number of boreholes meeting the criteria of $\mathrm{Cu}_{\mathrm{e}}$ productivity $\geq 35 \mathrm{~kg} / \mathrm{m}^{2}$ (Table 4). Hypothetical resources include those directly adjacent to deposits that are identified, speculative resources with high potential includes resources in areas distant from identified deposits, designated by more than one hole, and speculative resources with low potential represent resources designated by a single hole.

Table 4. Criteria for classification of prospective resources within prospective areas.

\begin{tabular}{ccc}
\hline $\begin{array}{c}\text { Category of Prospective } \\
\text { Resources }\end{array}$ & $\begin{array}{c}\text { Location of the Area in Relation } \\
\text { to Documented Copper Deposits }\end{array}$ & $\begin{array}{c}\text { Number of Boreholes with Cu} \\
\text { Productivity } \geq \mathbf{3 5} \mathbf{~ k g} / \mathbf{m}^{\mathbf{2}}\end{array}$ \\
\hline Hypothetical & Proximal area & $>1$ \\
Speculative of high potential & Distal area & $>1$ \\
Speculative of low potential & Distal area & 1 \\
\hline
\end{tabular}

It should be clearly stated that the current resource estimates in these areas have been determined by geometric interpolation unevenly distributed drill holes.

\section{Identified Resources}

\subsection{Operated Copper Deposits of the Fore-Sudetic Monocline}

There are six mining license areas within the Lubin-Sieroszowice mining district of the Fore-Sudetic Monocline: Głogów Głęboki, Lubin-Małomice, Polkowice, Radwanice-Gaworzyce, Rudna and 
Sieroszowice (Figure 7; Table 5). KGHM Polska Miedź S.A. has the mining concessions for all of them. As of 2018 and according to the 2005 cut-off criteria (Table 3), the identified resources (including measured, indicated and inferred resources) in the operated area are 1663.026 Mt of ore containing $30.376 \mathrm{Mt} \mathrm{Cu}$ and $86.853 \mathrm{kt} \mathrm{Ag}$ (Table 4). Economic reserves are 23.741 $\mathrm{Mt} \mathrm{Cu}$ and $45.064 \mathrm{kt} \mathrm{Ag}$.

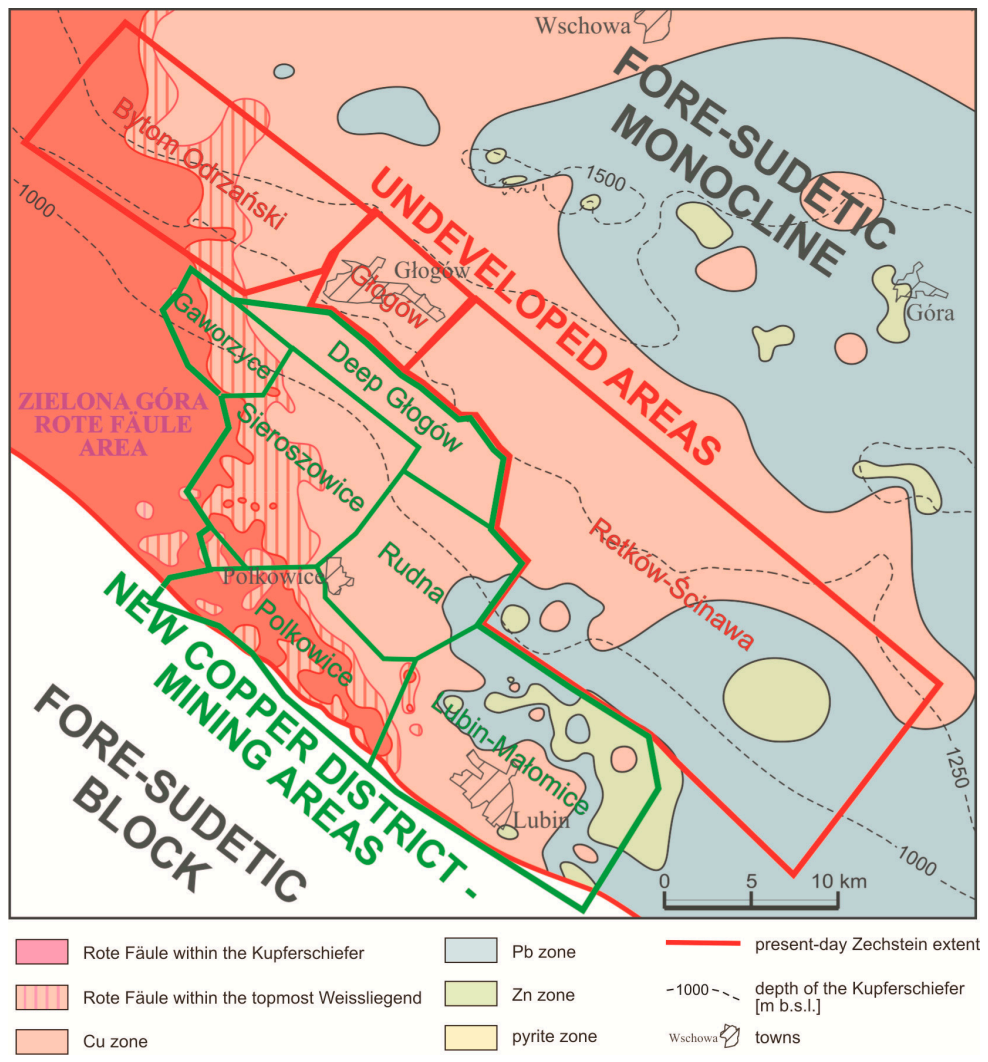

Figure 7. The Lubin-Sieroszowice Copper District showing mining and undeveloped areas.

Table 5. Identified resources and production in 2018 in developed deposits in the Fore-Sudetic Monocline. Modified after Malon et al. [25].

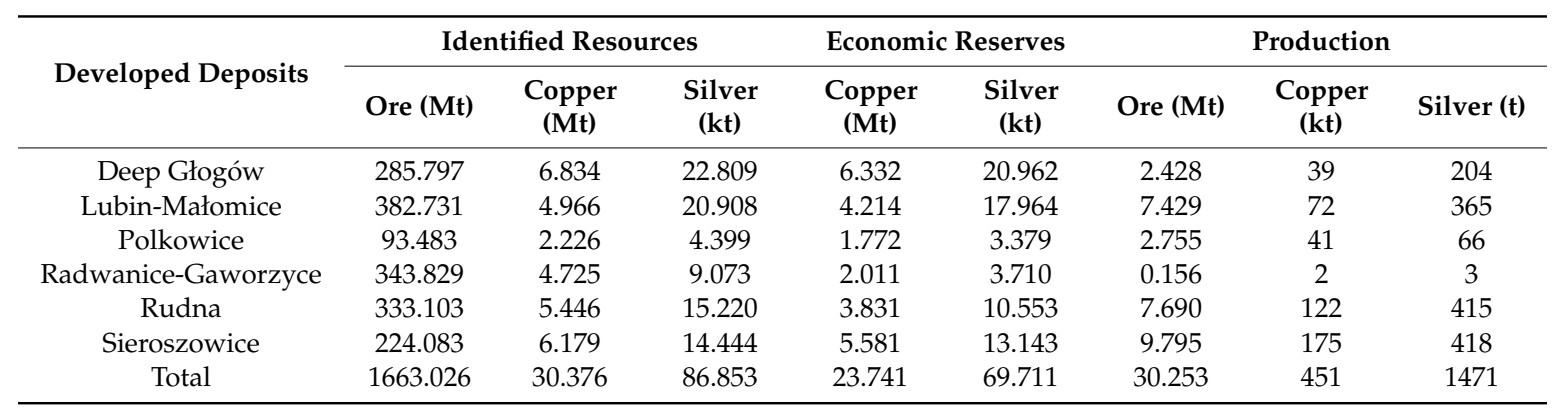

The average copper content in the Lubin-Sieroszowice deposit is $1.63 \%$ and 57 ppm of silver; maximum average contents are typical of the shale ore $(5.4 \% \mathrm{Cu}, 134 \mathrm{ppm} \mathrm{Ag})$. The average silver content in $\mathrm{Cu}-\mathrm{Ag}$ ore grows systematically from areas with chalcocite-covellite mineralization (42-56 ppm Ag) towards areas with bornite-chalcopyrite mineralization (58-86 ppm), while in Pb-Zn and pyrite areas the silver content falls below 20 ppm. Silver shows a correlation with copper. 


\subsection{Undeveloped Copper Deposits of the Fore-Sudetic Monocline and the North Sudetic Trough}

Undeveloped deposits with identified economic resources in the Fore-Sudetic Monocline include: Bytom Odrzański, Głogów and Retków (Figure 7; Table 6). The identified economic resources in the undeveloped ore deposits are 139.535 Mt of ore comprising 2.244 Mt of $\mathrm{Cu}$ and $11.085 \mathrm{kt}$ of Ag. Apart from these resources, inferred marginal resources of $764.891 \mathrm{Mt}$ of ore comprising $12.754 \mathrm{Mt} \mathrm{Cu}$ and $40.518 \mathrm{kt} \mathrm{Ag}$ have been documented (Table 6); these resources are marginally economic because of their depth which ranges from 1250 to $1500 \mathrm{~m}$ at the time of determination according to the 2005 threshold values (Table 3). All undeveloped copper deposits adjacent to the northern margin of the Lubin-Sieroszowice mining areas are considered to be the most prospective resource base for copper ore mining.

Table 6. Identified resources per 2018 in undeveloped areas adjacent to mining areas, the Fore-Sudetic Monocline. Modified after Malon et al. [25].

\begin{tabular}{ccccccc}
\hline \multirow{2}{*}{$\begin{array}{c}\text { Undeveloped } \\
\text { Deposits }\end{array}$} & \multicolumn{2}{c}{ Identified Economic Resources } & \multicolumn{2}{c}{ Inferred Marginal Resources } \\
\cline { 2 - 6 } & Ore (Mt) & Copper (Mt) & Silver (kt) & Ore (Mt) & Copper (Mt) & Silver (kt) \\
\hline Bytom & 2.247 & 0.093 & 0.054 & 169.551 & 3.271 & 6.517 \\
Odrzański & - & - & - & 276.951 & 4.780 & 19.550 \\
Głogów & 137.288 & 2.151 & 11.031 & 318.389 & 4.703 & 14.451 \\
Retków & 139.535 & 2.244 & 11.085 & 764.891 & 12.754 & 40.518 \\
Total & & & &
\end{tabular}

Most of the area of the North Sudetic Trough is developed as reduced Zechstein sediments. Oxidized rocks, underlaying copper-bearing intervals were found in the eastern parts of the OCD and at the border of the North Sudetic Trough with the Żary Pericline. Rich copper mineralization occurs only in the eastern part of the North Sudetic Trough $[36,103,104]$. There are three undeveloped deposits: Nowy Kościól, Niecka Grodziecka and Wartowice (Table 7). The first two deposits have previously been mined. Despite the cessation of mine production in the OCD (Lena in 1973, Nowy Kościól in 1967 and Konrad in 1989), the identified resources of these deposits are included in the balance of mineral resources of Poland because the discontinuation of production at the Lena, Nowy Kościół and Konrad mines occurred as a result of an economic downturn and not due to the depletion of resources. In the Niecka Grodziecka ore occurs at the favorable depth from 50 to $900 \mathrm{~m}$, but reopening the mines will be difficult due to flooded underground workings. However, it is possible to start production in a part of this deposit. Nowy Kościół occurs in the very favorable depth range (50-360 m), but is characterized by a low metal content. In total, the identified economic resources of Niecka Grodziecka and Wartowice deposits at the time of determination amount to $89.607 \mathrm{Mt}$ of ore $(1.306 \mathrm{Mt} \mathrm{Cu}, 4.76 \mathrm{kt}$ $\mathrm{Ag}$ ) at various depths, ranging between 50-1400 m, and in the Nowy Kościół deposit 13.48 Mt of ore (0.12 Mt Cu, 583 tons of $\mathrm{Ag}$ ). They are accompanied by marginally economic resources (Table 7).

Table 7. Identified resources per 2018 in undeveloped areas of the North Sudetic Trough. Modified after Malon et al. [25].

\begin{tabular}{ccccccc}
\hline \multirow{2}{*}{$\begin{array}{c}\text { Undeveloped } \\
\text { Deposits }\end{array}$} & \multicolumn{2}{c}{ Identified Economic Resources } & \multicolumn{2}{c}{ Inferred Marginal Resources } \\
\cline { 2 - 7 } & Ore (Mt) & Copper (Mt) & Silver (kt) & Ore (Mt) & Copper (Mt) & Silver (kt) \\
\hline Niecka & 10.291 & 0.141 & 501 & 2.205 & 0.030 & 70 \\
Grodziecka & 79.316 & 1.165 & 4.260 & 17.286 & 0.201 & 582 \\
Wartowice & 13.478 & 0.116 & 583 & 15.878 & 0.102 & 608 \\
Nowy Kościół & 103.085 & 1.422 & 5.344 & 35.369 & 0.333 & 1260 \\
Total & & & &
\end{tabular}




\section{Prospective Areas}

\subsection{Hypothetical Resources}

In the area of the Fore-Sudetic Monocline, four prospective areas with hypothetical resources are identified: Białołęka, Jany-Nowa Sól-Grochowice, Kulów and Luboszyce, occurring in the immediate vicinity of the Lubin-Sieroszowice deposit (Figure 8). They are the most significant prospective areas as they may constitute a backup resource base for the copper mining industry still requiring further detailed investigation. In general, in the Fore-Sudetic Monocline over a total area of $414.99 \mathrm{~km}^{2}$, there may be 42,494 Mt of $\mathrm{Cu}$ and $174 \mathrm{kt}$ of $\mathrm{Ag}$ with the average thickness ranging from 1.4 to $2.0 \mathrm{~m}$ and with the average grade in the range of 0.8-3.1\% Cu and 50-100 ppm Ag at depths between 1400 and $2200 \mathrm{~m}$ (Table 8). An additional prospect (Raciborowice) is located in the North Sudetic Trough.

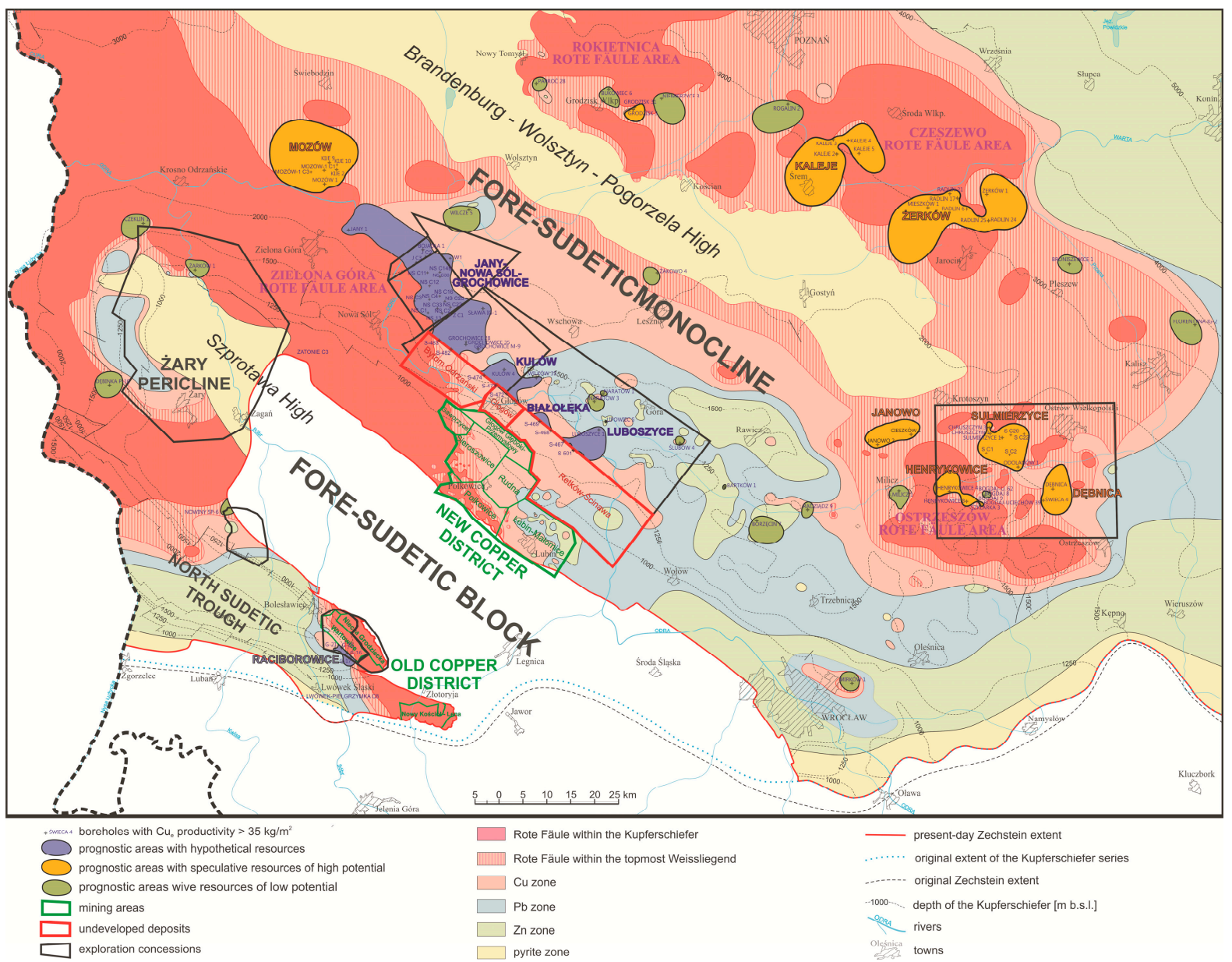

Figure 8. The current state of knowledge on prospective copper areas in relation to Rote Fäule areas and metal zonation (modified after Oszczepalski et al. [24]).

Jany-Nowa Sól-Grochowice: This is an area with the highest potential in the group of hypothetical resources. It occurs directly north-west of the documented L-S deposits. First exploratory boreholes were drilled by the PGI-NRI in 1970-1979 (e.g., Sława IG 1 and Grochowice M 9). Later, tens of gas exploration boreholes were drilled by PGNiG. 
Table 8. Prospective copper and silver resources in the Zechstein series of SW Poland.

\begin{tabular}{|c|c|c|c|c|c|c|c|c|}
\hline $\begin{array}{l}\text { Resource } \\
\text { Category }\end{array}$ & $\begin{array}{l}\text { Prospective } \\
\text { Area }\end{array}$ & $\begin{array}{l}\text { Area } \\
\left(\mathrm{km}^{2}\right)\end{array}$ & $\begin{array}{c}\text { Depth } \\
\text { Range } \\
\text { (MBGL) }\end{array}$ & $\begin{array}{l}\text { Av. } \\
\text { Thick. } \\
\text { (m) }\end{array}$ & $\begin{array}{c}\text { Av. Cu } \\
\text { Content } \\
(\%)\end{array}$ & $\begin{array}{l}\text { Cu Res. } \\
\text { (Mt) }\end{array}$ & $\begin{array}{l}\text { Av. Ag } \\
\text { Cont. } \\
\text { (ppm) }\end{array}$ & $\underset{(\mathrm{kt})}{\mathrm{Ag} \text { Res. }}$ \\
\hline \multirow{5}{*}{ Hypothetical } & Białołęka & 6.81 & $1500-1600$ & 1.80 & 1.08 & 0.331 & 51 & 1.563 \\
\hline & $\begin{array}{c}\text { Jany-Nowa } \\
\text { Sól-Grochowice }\end{array}$ & 320.07 & $1600-2200$ & 1.93 & 2.25 & 34.748 & 96 & 148.256 \\
\hline & Kulów & 49.68 & $1500-1800$ & 1.59 & 3.14 & 6.201 & 86 & 16.983 \\
\hline & Luboszyce & 38.43 & $1400-1600$ & 1.42 & 0.89 & 1.214 & 53 & 7.231 \\
\hline & Raciborowice & 7.57 & $900-1500$ & 3.75 & 0.79 & 0.561 & 24 & 1.703 \\
\hline \multicolumn{2}{|c|}{ Total } & 422.56 & 900-2200 & & 43.055 & & \multicolumn{2}{|c|}{175.736} \\
\hline \multirow{9}{*}{$\begin{array}{l}\text { Speculative of } \\
\text { high potential }\end{array}$} & Dębnica & 50.40 & $1500-1800$ & 0.51 & 6.21 & 3.990 & 167 & 10.731 \\
\hline & Grodzisk & 10.70 & $2700-2800$ & 1.07 & 3.54 & 1.013 & 94 & 2.690 \\
\hline & Henrykowice & 28.90 & $1400-1700$ & 1.08 & 1.73 & 1.350 & 34 & 2.653 \\
\hline & Janowo & 42.98 & $1700-1800$ & 1.11 & 1.64 & 1.956 & 36 & 4.294 \\
\hline & Kaleje & 196.68 & $2700-3400$ & 2.30 & 2.75 & 31.100 & 26 & 29.404 \\
\hline & Mozów & 213.99 & $2300-2600$ & 2.09 & 2.71 & 30.300 & 50 & 55.905 \\
\hline & Sulmierzyce & 75.82 & $1600-2100$ & 1.49 & 2.75 & 7.767 & 63 & 17.793 \\
\hline & Żerków & 263.70 & $2600-3600$ & 1.51 & 2.40 & 23.891 & 55 & 54.751 \\
\hline & Total & 883.17 & $1400-3600$ & & 101.367 & & \multicolumn{2}{|c|}{178.221} \\
\hline \multirow{23}{*}{$\begin{array}{l}\text { Speculative of } \\
\text { low potential }\end{array}$} & Bartków & 0.47 & $1300-1400$ & 0.32 & 4.18 & 0.016 & 71 & 0.027 \\
\hline & Bogdaj & 2.08 & $1400-1500$ & 1.58 & 1.52 & 0.125 & 34 & 0.279 \\
\hline & Borzęcin & 32.15 & $1400-1600$ & 0.51 & 4.91 & 2.013 & - & - \\
\hline & Broniszewice & 15.10 & $2100-2200$ & 0.46 & 5.97 & 1.037 & 142 & 2.466 \\
\hline & Bukowiec & 12.23 & $2700-2800$ & 0.60 & 2.87 & 0.526 & 89 & 1.633 \\
\hline & Czeklin & 23.48 & $1700-1800$ & 0.23 & 10.54 & 1.423 & - & - \\
\hline & Dębinka & 25.39 & $1400-1600$ & 2.30 & 0.69 & 1.007 & 44 & 6.424 \\
\hline & Florentyna & 33.68 & $3700-4000$ & 1.00 & 2.66 & 2.240 & 33 & 2.779 \\
\hline & Lipowiec & 0.16 & $1400-1500$ & 0.60 & 2.06 & 0.005 & 64 & 0.015 \\
\hline & Milicz & 13.93 & $1600-1700$ & 1.86 & 0.89 & 0.576 & 26 & 1.684 \\
\hline & Mirków & 12.69 & $1100-1300$ & 1.17 & 1.56 & 0.579 & - & - \\
\hline & Naratów 1 & 1.80 & $1500-1600$ & 0.55 & 3.99 & 0.009 & 319 & 0.789 \\
\hline & Naratów 3 & 8.15 & $1400-1500$ & 0.52 & 2.07 & 0.219 & 86 & 0.911 \\
\hline & Niemierzyce & 32.35 & $2700-2900$ & 1.00 & 4.16 & 3.364 & 21 & 1.698 \\
\hline & Nowiny & 5.72 & $400-600$ & 0.47 & 2.64 & 0.177 & 100 & 0.672 \\
\hline & Paproć & 6.41 & $2500-2700$ & 0.10 & 17.27 & 0.277 & 421 & 0.675 \\
\hline & Radziądz & 6.44 & $1600-1800$ & 1.65 & 0.93 & 0.247 & 7 & 0.186 \\
\hline & Rogalin & 54.36 & $2900-3200$ & 1.90 & 1.42 & 3.667 & 7 & 1.807 \\
\hline & Ślubów & 2.51 & $1300-1400$ & 0.20 & 9.08 & 0.114 & 164 & 0.206 \\
\hline & Wilcze & 35.58 & $2400-2500$ & 0.23 & 8.12 & 1.661 & 920 & 18.882 \\
\hline & Żakowo & 10.33 & $2100-2300$ & 0.40 & 3.36 & 0.347 & 45 & 0.465 \\
\hline & Żarków & 13.19 & $1200-1500$ & 3.01 & 1.34 & 1.330 & 22 & 2.184 \\
\hline & & 348.20 & $400-4000$ & & 20.959 & & \multicolumn{2}{|c|}{43.782} \\
\hline \multicolumn{2}{|c|}{$\begin{array}{l}\text { Total hypothetical and speculative } \\
\text { resources }\end{array}$} & 1653.9 & $400-4000$ & & 165.381 & & \multicolumn{2}{|c|}{397.739} \\
\hline
\end{tabular}

In the north-western part of the area ore mineralization forms an embayment in the eastern part of the Zielona Góra oxidized area, constituting the Jany subarea. Since the early 1970s, only the prospective areas of Jany (Jany 1 borehole) and Grochowice (Grochowice M-9 and Sława IG 1) were shown in assessments by studies of oil and gas boreholes in the Zielona Góra region [18]. Those boreholes were drilled in an irregular grid, but they formed some clusters (e.g., the Grochowice-Kulów area; Figure 8). Despite this, those holes later allowed four favorable areas to be identified: Jany, Grochowice, Sława and Kulów [21-24]. These prospective areas rim the vast Zielona Góra oxidized area, where the Lower Zechstein sediments are intensely oxidized (Figures 4-6 and 8). The redox boundary moves from the Lower Anhydrite in the west to lower parts of the Weissliegend sandstones in the east (Figure 9). This oxidized area is characterized by the pervasive destruction of organic matter and replacement of pyrite and copper sulfides by hematite [48]. There are common relicts of covellite, digenite, chalcocite, chalcopyrite and pyrite among extensive replacement of copper and iron sulfides by hematite. Hematite pseudomorphs after framboidal pyrite are abundant in the oxidized 
Kupferschiefer. Oxidized rocks are typically enriched in Au and PGE [22,81], native gold, electrum, silver amalgam and auricuprite were also found.

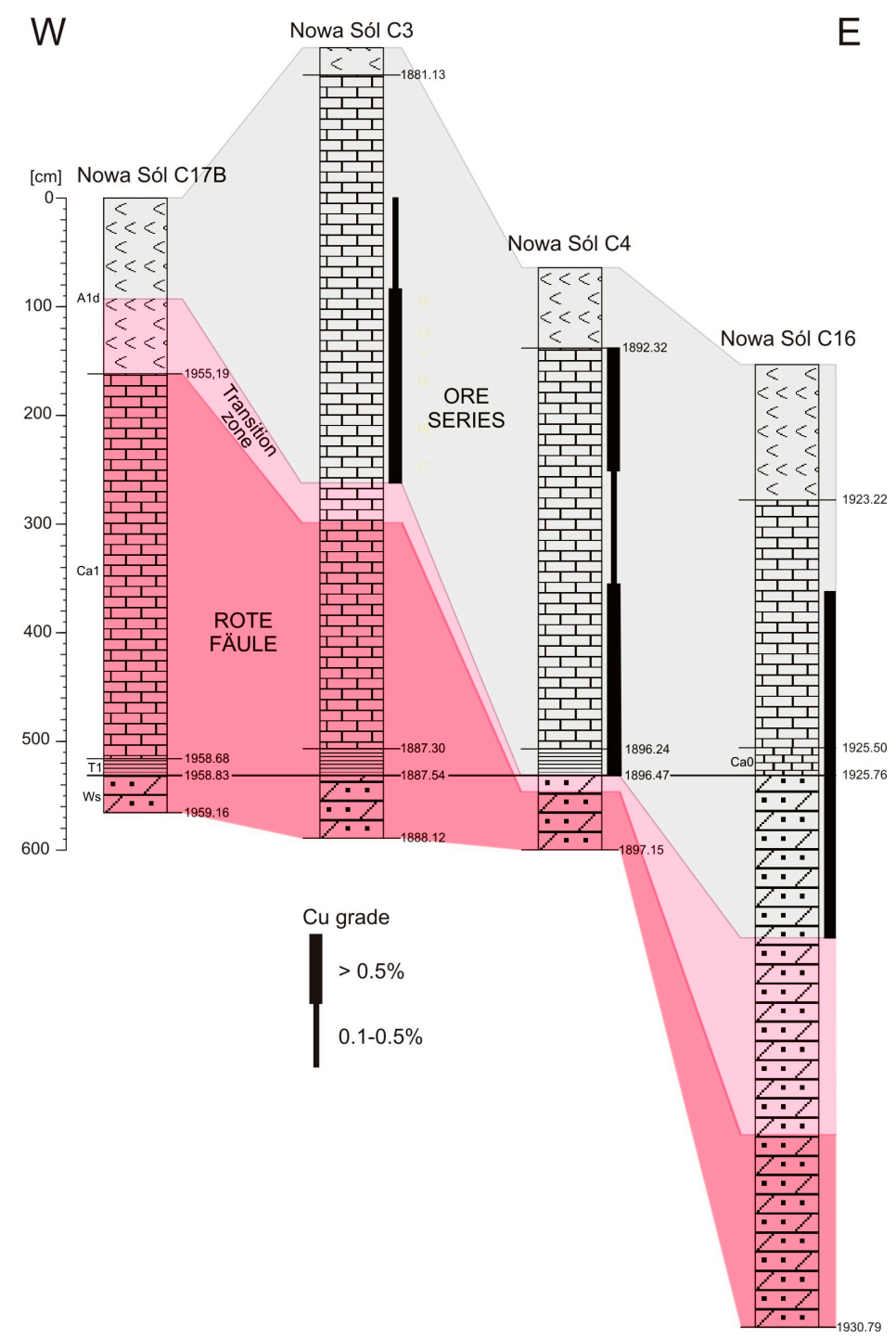

Figure 9. Crosscutting nature of the Rote Fäule front in the Jany-Nowa Sól-Grochowice prospective area (for legend see Figure 4).

In the Jany subarea (Figure 3) the ore interval includes the upper part of the Kupferschiefer and the lower part of the Zechstein Limestone, with a maximum content of up to $10.61 \% \mathrm{Cu}$ [21]. Chalcocite-covellite dominates over bornite and digenite. The Grochowice subarea in the immediate vicinity of the Bytom Odrzański deposit is better delineated by four positive boreholes: Grochowice 28, Grochowice 35, S-483 and S-482 (Figure 8). In these boreholes mineralization is present in the Weissliegend and dominated by $\mathrm{Cu}-\mathrm{S}$ sulfides (chalcocite, digenite, covellite) and bornite, while the Kupferschiefer is mineralized with $\mathrm{Cu}-\mathrm{Fe}-\mathrm{S}$ sulfides (bornite and chalcopyrite), minor tennantite, galena, sphalerite and pyrite [24]. In the SW part of the Grochowice subarea, Cu-S mineralization is predominant, whereas in the eastern part bornite-chalcocite mineralization is most common, with a significant share of sphalerite and galena. Consequently, in the eastern part of the discussed area the Kupferschiefer samples are characterized by a distinctive increase in the concentration of $\mathrm{Zn}$ (up to $3 \%$ ) and $\mathrm{Pb}$ (up to 1.5\%). The maximum copper contents were found in Kupferschiefer samples (S-482-17.65\% and Grochowice 35-7.17\%) as well as in Weissliegend specimens (Grochowice $35-2.84 \%$ and S- $483-1.80 \%$ ). The silver content is high especially in Kupferschiefer samples (up to 
600 ppm in S-482 and up to 564 ppm in Grochowice 35). The most abundant mineralization has been recorded in the S-482 borehole, in which an interval $0.45 \mathrm{~m}$ with an average content of $4.89 \% \mathrm{Cu}$ and $298 \mathrm{ppm} \mathrm{Ag}$ is characterized by $\mathrm{Cu}_{\mathrm{e}}$ productivity of $88.49 \mathrm{~kg} / \mathrm{m}^{2}$. In the northern and eastern parts of this area (e.g., Sława IG 1), mineralization is poorer and polymetallic (chalcocite, bornite, galena, sphalerite, pyrite and chalcopyrite) placed only in the Kupferschiefer and the Weissliegend.

Taking into account the spatial distribution of prospective areas on the reduced side of the redox border it was stated that, just as in the case of the western part of the Lubin-Sieroszowice deposit, $\mathrm{Cu}-\mathrm{Ag}$ orebodies were expected to occur in the nearest neighborhood of the Zielona Góra oxidized area forming a northwest-trending copper belt that rims the oxidized area $[18,20,21,24,43]$.

In order to find a new deposit between those subareas in the immediate vicinity of the Zielona Góra Rote Fäule area, MCC developed a greenfield exploration program for the Nowa Sól area. The project followed the granting of exploration concessions by the Minister of Environment in 2011. It should be strongly emphasized that until exploration by MCC there were no prospecting boreholes drilled anywhere between the Grochowice and Jany subareas. Detailed results are presented in the final part of this article.

The recent drilling confirmed the presence of the copper belt [48-50]. The current boundaries of the Jany-Nowa Sól-Grochowice prospective area have been determined by taking into account the results of 24 boreholes drilled by MCC in the Nowa Sól area (Figure 8). This prospect covers an area of $320.07 \mathrm{~km}^{2}$ and contains approx. $35 \mathrm{Mt}$ of $\mathrm{Cu}$ and $148 \mathrm{kt}$ of Ag over an interval having average thickness of $1.93 \mathrm{~m}$ and an average grade of $2.25 \% \mathrm{Cu}$ and $96 \mathrm{ppm} \mathrm{Ag}$ (Table 8). The depth to the Zechstein base varies from $1600 \mathrm{~m}$ in the south to $2200 \mathrm{~m}$ in the north.

Kulów: This area adjacent to the north-eastern part of the Bytom Odrzański deposit and to the north-western part of the Głogów deposit was outlined by six drill holes (Figure 8). Chalcocite-bornite mineralization prevails. The S-473 drillhole has the most abundant ore mineralization in an interval of $1.44 \mathrm{~m}$, with an average grade of $2.60 \% \mathrm{Cu}_{\mathrm{e}}$ and $181 \mathrm{ppm} \mathrm{Ag}$, and it is characterized by $\mathrm{Cu}_{\mathrm{e}}$ productivity of $157.76 \mathrm{~kg} / \mathrm{m}^{2}$. This area covers $49.68 \mathrm{~km}^{2}$ with the Zechstein base at fairly favorable depths from 1500 to $1700 \mathrm{~m}$. The copper-bearing interval with a thickness of $1.59 \mathrm{~m}$ and an average content of $3.14 \%$ $\mathrm{Cu}$ and 86 ppm Ag contains approx. 6.201 Mt of $\mathrm{Cu}$ and almost 17 thousand tons of Ag.

Białołęka: This area is adjacent to the border of the Głogów and Retków deposits. It was identified with two boreholes with rich copper-silver mineralization: S-468 and S-469, and by the $35 \mathrm{~kg} / \mathrm{m}^{2} \mathrm{Cu}$ contour. Chalcocite-bornite mineralization is predominant. The richest mineralization is shown in S-469, in which an interval of $2.7 \mathrm{~m}$ with an average grade of $1.3 \% \mathrm{Cu}$ and $44 \mathrm{ppm} \mathrm{Ag}$ is characterized by $\mathrm{Cu}_{\mathrm{e}}$ productivity of $112.74 \mathrm{~kg} / \mathrm{m}^{2}$. S-468 is slightly poorer $(1.52 \mathrm{~m}$ thick, $0.83 \% \mathrm{Cu}$ on average and $44 \mathrm{ppm} \mathrm{Ag}$, and $\mathrm{Cu}_{\mathrm{e}} 46.16 \mathrm{~kg} / \mathrm{m}^{2}$ ). In this area restricted to only $6.81 \mathrm{~km}^{2}$, a resource of approx. $0.331 \mathrm{Mt}$ of $\mathrm{Cu}$ and $1.563 \mathrm{kt}$ of $\mathrm{Ag}$ is estimated over a thickness of $1.80 \mathrm{~m}$ at $1.08 \% \mathrm{Cu}$ and $51 \mathrm{ppm} \mathrm{Ag}$, at a depth in the range of 1500-1600 $\mathrm{m}$.

Luboszyce: This area is directly adjacent to the Retków deposit was intersected by drill holes: S-467 and S-501. In the northern part of this area, the Luboszyce 1 borehole in the 1990s became a basis for determining a prospective area [18]. It is characterized by the most favorable deposit parameters (an interval of $1.9 \mathrm{~m}$ in thickness, an average content of $0.8 \% \mathrm{Cu}$ and $42 \mathrm{ppm} \mathrm{Ag}$ and $\mathrm{Cu}_{\mathrm{e}}$ productivity of $56.26 \mathrm{~kg} / \mathrm{m}^{2}$ ). Mineralization in this area is very variable in the vertical profile: In sandstones copper sulfides (bornite, digenite, covellite and chalcocite) with minor sphalerite and galena prevail, while in the shale-carbonate series, galena and secondary sphalerite, bornite, digenite, covellite and chalcocite are dominant. For the fairly large area of $38.43 \mathrm{~km}^{2}$, a resource of $1.214 \mathrm{Mt}$ of $\mathrm{Cu}$ and approx. seven thousand tons of $\mathrm{Ag}$ are estimated with the average thickness of $1.42 \mathrm{~m}$, and the average grade of 0.89\% Cu and 53 ppm Ag. Resources are placed between 1400 and $1600 \mathrm{~m}$.

Raciborowice: This area was outlined in the North Sudetic Trough where it adjoins the documented Wartowice deposit. It is identified by the boreholes documenting the Wartowice deposit: G-14, G-15, G-16 and G-17 along with $35 \mathrm{~kg} / \mathrm{m}^{2} \mathrm{Cu}_{\mathrm{e}}$ productivity. In the drill holes, parameters of the deposit range between $1.9-4.35 \mathrm{~m}, 0.94-1.6 \% \mathrm{Cu}$ and $47.39-119.02 \mathrm{~kg} / \mathrm{m}^{2} \mathrm{Cu}$ e productivity. The average 
silver content is in a wide range from 20 to $160 \mathrm{ppm}$. The depth of the Zechstein base changes from $900 \mathrm{~m}$ in the south-eastern part to $1500 \mathrm{~m}$ in the NW part of this area. The prospect is partially delimited from the south-west by five drill holes with $\mathrm{Cu}_{\mathrm{e}}$ below $35 \mathrm{~kg} / \mathrm{m}^{2}$. The composition of ore minerals is dominated by: Chalcocite, bornite and chalcopyrite, locally with admixtures of digenite, covellite, tetrahedrite, tennantite, galena, sphalerite, pyrite and native silver (mainly in the form of tiny inclusions) in chalcocite. The contribution of bornite, chalcopyrite, galena and sphalerite generally increases at the expense of chalcocite in the SW direction and towards the top of the ore-bearing intervals. In this area, $0.561 \mathrm{Mt}$ of $\mathrm{Cu}$ and $1.703 \mathrm{kt}$ of $\mathrm{Ag}$ can be expected in the interval that averages $3.75 \mathrm{~m}$ thickness and has an average grade of $0.79 \% \mathrm{Cu}$ and $24 \mathrm{ppm} \mathrm{Ag}$. Due to the increased $\mathrm{Cu}_{\mathrm{e}}$ productivity (in a range of 8.22 to $18.72 \mathrm{~kg} / \mathrm{m}^{2} \mathrm{Cu}_{\mathrm{e}}$ ) in boreholes surrounding the area, an extension of the prospective area can be expected towards the Nowy Kościół deposit, forming a copper belt 5-10 km wide, with mineralization at a depth of less than $900 \mathrm{~m}$ under favorable geological and mining conditions. It is likely that this hypothesis will be verified in the future, as the discussed area located south of current exploration license owned by KGHM (Synklina Grodziecka and Konrad) is a site of an ongoing exploration drilling project.

\subsection{Speculative Resources of High Potential}

This group of speculative resources includes four prospective areas (Dębnica, Henrykowice, Janowo and Sulmierzyce) with high potential at depths of 1400-2100 $\mathrm{m}$ and four further prospective areas identified at depths ranging from 2300 to 3600 m (Grodzisk, Żerków, Kaleje and Mozów). All these areas are directly adjacent to the oxidized zone.

Prospects from the first group (Debnica, Henrykowice, Janowo and Sulmierzyce) belong to the mineralization system located in the eastern part of the Fore-Sudetic Monocline and are approximately $15 \mathrm{~km}$ to the east of the Lubin-Sieroszowice $\mathrm{Cu}-\mathrm{Ag}$ deposit. They are related to the Ostrzeszów oxidized area and numerous smaller oxidized zones scattered around it (Figure 8). The association of rich copper mineralization with the large Ostrzeszów Rote Fäule area is comparable (in both the degree of concentration and the relative position of the redox boundary in the horizontal and vertical distribution) to well-known ore mineralization in the western part of the Lubin-Sieroszowice deposit. Ore mineralization occurs here in the Weissliegend, the Kupferschiefer and the Zechstein Limestone (Dębnica and Janowo) above the oxidized Weissliegend and the Basal Limestone (Henrykowice), or above the oxidized bottom of the Kupferschiefer (Sulmierzyce).

These prospective areas have been investigated since the 1960s based on tens of promising drill holes, oxidative alteration, a high paleothermal heat flow and their geotectonic setting [18,19,43,44,97]. Cores from 74 boreholes were studied previously in these areas [21,44], and 62 drill holes were additionally investigated during the last two years. In order to delineate the extent of these prospective areas, they are currently being explored by drilling in the Sulmierzyce exploration license. The density of drilling allows a possibility that these four areas may actually be continuous and could be connected to neighboring smaller prospective areas, such as Milicz and Bogdaj (Figure 8). Areas from the second group with a depth exceeding $2300 \mathrm{~m}$ are found on both sides of the Wolsztyn elevation, which is characterized by both the lack of the Kupferschiefer and the presence of pyrite mineralization. These areas are quite well recognized by many drill holes with high values of deposit quality parameters. For these reasons, despite their considerable depth, they were the subject of exploration licenses in the previous years.

Dębnica: This area is located south of the Sulmierzyce area. It is intersected by two boreholes: Debnica 1 and Świeca 4. Similarly to the area of Sulmierzyce ore mineralization occurs in the Kupferschiefer as well as in the lower parts of the Zechstein Limestone, just above the oxidized Weissliegend. A bornite-chalcocite association dominates in this area, with minor digenite and covellite (in the lower part of the profiles), as well as chalcopyrite with bornite and pyrite (in the upper part of the mineralized interval). In this area which covers approx. $50 \mathrm{~km}^{2}$, there may be $3.99 \mathrm{Mt}$ of $\mathrm{Cu}$ and $10.731 \mathrm{kt}$ of $\mathrm{Ag}$ in an average interval of $1.49 \mathrm{~m}$ thickness and $2.75 \% \mathrm{Cu}$ and $63 \mathrm{ppm} \mathrm{Ag}$. The ore series 
is found at depths of $1700-1800 \mathrm{~m}$. It is presumed that this area connects with the Sulmierzyce area, but there are no boreholes to confirm this possibility [21].

Henrykowice: This area forms an embayment within the Ostrzeszów Rote Fäule area, partly overlapping both flanks of the oxidized zone. In this area there are five boreholes with the minimum productivity of $35 \mathrm{~kg} / \mathrm{m}^{2}$ : Bogdaj 9, Bogdaj-Uciechów 39, Henrykowice 4 and 8 and Szklarka 3. In the western and southern part of the Henrykowice area ore mineralization occurs in the Zechstein Limestone above the oxidized Kupferschiefer but in the eastern part it is found in the Kupferschiefer and in the uppermost Weissliegend. The ore contains covellite, digenite and chalcocite with minor bornite. Most favorable parameters were recorded in the Henrykowice 4 borehole (thickness $1.3 \mathrm{~m}$, $1.97 \% \mathrm{Cu}, 56 \mathrm{ppm} \mathrm{Ag}$ and $83.66 \mathrm{~kg} / \mathrm{m}^{2} \mathrm{Cu}_{\mathrm{e}}$ ). In this area that covers $28.9 \mathrm{~km}^{2}$, the resources may amount to $1.350 \mathrm{Mt}$ of $\mathrm{Cu}$ and $2.653 \mathrm{kt}$ of $\mathrm{Ag}$ at a depth of $1400-1700 \mathrm{~m}$. There is little possibility of enlarging the prospective area, although its connection with the neighboring areas of Sulmierzyce, Bogdaj and Milicz is not excluded.

Janowo: This area is located northwest of the oxidized Ostrzeszów area. The boundaries of this area were initially established around the Janowo 2 borehole. Rich chalcocite-bornite mineralization occurs in the Kupferschiefer and the Zechstein Limestone above the oxidized sandstones. The resources at this area amount to $1.956 \mathrm{Mt}$ of $\mathrm{Cu}$ and $4.294 \mathrm{kt}$ of $\mathrm{Ag}$ in an area of $42.98 \mathrm{~km}^{2}$. The depth of the Zechstein base ranges between 1700 and $1800 \mathrm{~m}$.

Sulmierzyce: This is an area with potentially significant mineralization. It was considered prospective in the 1970s based on rich mineralization in the Sulmierzyce 1 borehole [19]. Investigations made in later years $[18,44]$ showed that this area intersected by another three boreholes: Chruszczyn 1, Chruszczyn 3 and Odolanów 1 is surrounded by seven oxidized zones [24]. In the recent years, MCC drilled five more boreholes (Figure 8). Four of them confirmed the presence of rich copper mineralization in this area slightly extending the range of the prospect to the north-east. In the northern part, where the Chwaliszew oxidized area occurs, the lower part of the copper-bearing series is oxidized (e.g., S C19) whilst southwards oxidation affects sandstones or even the lowermost portion of the Kupferschiefer (Sulmierzyce 1, S C2, S C20; Figure 10). Only in Odolanów 1 located at the southern end of the area does mineralization occurs also in the Weissliegend. Maximum $\mathrm{Cu}_{\mathrm{e}}$ productivity was recorded in Sulmierzyce 1-224.94 kg/m (no Ag analyses) and the new S C1 and S C20 boreholes. A chalcocite-bornite association prevails in the discussed area, with minor digenite and covellite. This area covers $75.82 \mathrm{~km}^{2}$ and contains about $7.767 \mathrm{Mt}$ of $\mathrm{Cu}$ and $17.793 \mathrm{kt}$ of $\mathrm{Ag}$, grading $2.1 \% \mathrm{Cu}$ and $26 \mathrm{~g} / \mathrm{t} \mathrm{Ag}$ at depths ranging between 1600 and $2100 \mathrm{~m}$. Thickness of the mineralized horizon is $1.49 \mathrm{~m}$. In terms of the amount of copper and its size, this is the most interesting prospective area in the eastern part of the Fore-Sudetic Monocline.

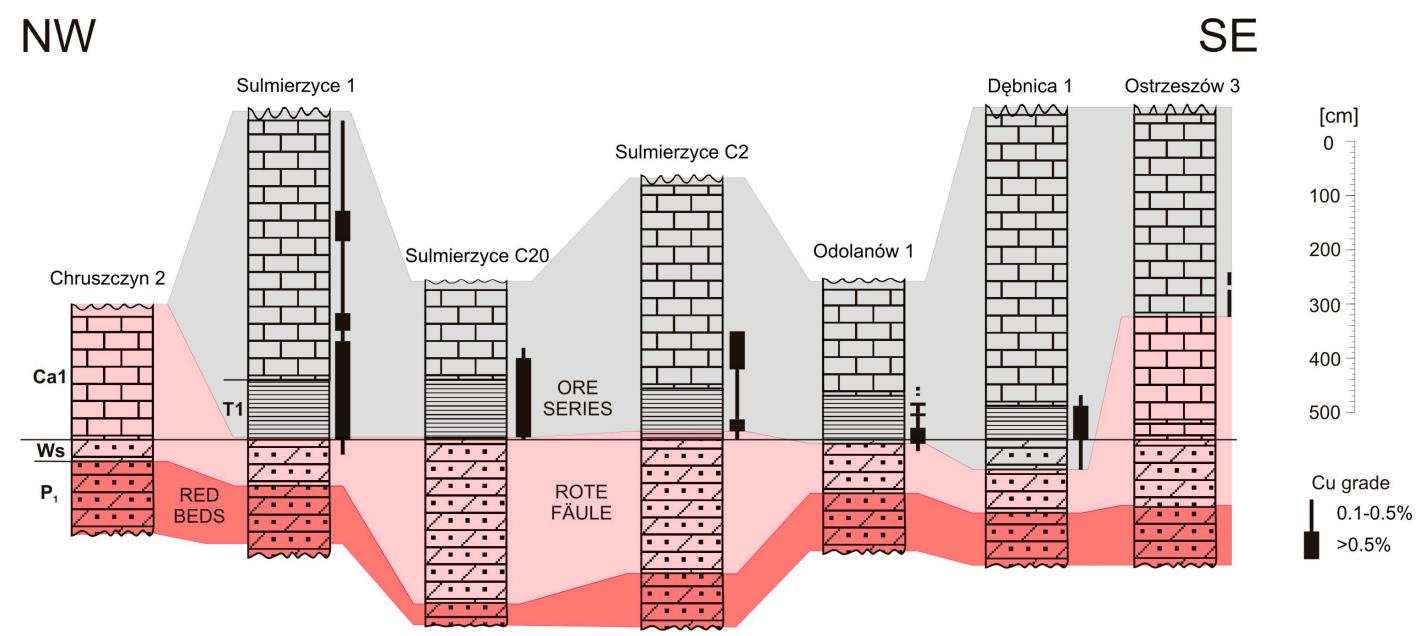

Figure 10. Vertical variation of the ore series relative to the oxidation front in the Sulmierzyce prospect (for legend see Figure 4). 
Grodzisk: It is a small and poorly examined area determined in recent years by two boreholes: Grodzisk 3 and Grodzisk 31, with sandstone ore in the center of the area and the shale-carbonate ore near oxidized rocks. Cu-S-type sulfides predominate. The area is located between the Rokietnica and Ujazd oxidized areas. The richest ore mineralization occurs in Grodzisk 31 with productivity of $109.84 \mathrm{~kg} / \mathrm{m}^{2}$. This area covers of $10.7 \mathrm{~km}^{2}$ with approximately $1.013 \mathrm{Mt}$ of $\mathrm{Cu}$ and $2.69 \mathrm{kt}$ of $\mathrm{Ag}$ in an average interval of $1.07 \mathrm{~m}$ and a grade of $3.54 \% \mathrm{Cu}$ and $94 \mathrm{ppm} \mathrm{Ag}$, at depths $2700-2800 \mathrm{~m}$.

Kaleje: This large area $\left(197 \mathrm{~km}^{2}\right)$ adjoins the western edge of the Czeszewo Rote Fäule. Initially delineated based on metal contents from Kaleje 4 and Kaleje 5 boreholes [18], the current range was obtained by investigation of boreholes: Kaleje 2 and Kaleje 3 [24]. In this area, shale-carbonate ore predominates and it is represented by the following ore minerals: Chalcocite, digenite and covellite. The thickness of the ore interval varies from 1.9 to $4.0 \mathrm{~m}$, the average content from $0.72 \%$ to $3.9 \% \mathrm{Cu}$ and from 24 to $28 \mathrm{ppm} \mathrm{Ag}$ (silver analyzed only in the Kaleje 2 and Kaleje 3 boreholes). Productivity varies from $74.59 \mathrm{~kg} / \mathrm{m}^{2} \mathrm{Cu}$ to $187.99 \mathrm{~kg} / \mathrm{m}^{2} \mathrm{Cu}$. The Kaleje area has resources of $31.1 \mathrm{Mt}$ of $\mathrm{Cu}$ and $29.404 \mathrm{kt}$ of $\mathrm{Ag}$ at depths between 2700 and $3400 \mathrm{~m}$. The mineralized interval averages $2.3 \mathrm{~m}, 2.75 \% \mathrm{Cu}$ and $26 \mathrm{ppm} \mathrm{Ag}$.

Żerków: The initial geochemical analyses obtained for Żerków 1 enabled the determination of a prospective area between the Czeszów and Łuszczanów oxidized area [18]. Currently, there are eight boreholes with $\mathrm{Cu}_{\mathrm{e}}$ productivity over $35 \mathrm{~kg} / \mathrm{m}^{2}$ : Żerków 1, Mieszków 1, Radlin 6, 17, 20, 21, 24 and 25 [24]. In these holes, shale-carbonate ore is mineralized mainly with chalcocite, digenite, covellite and bornite. The thickness of the ore interval varies from 1.14 to $2.88 \mathrm{~m}$, the average grade from $0.94 \%$ to $4.41 \% \mathrm{Cu}$ and from 22 to $96 \mathrm{ppm} \mathrm{Ag}$, and productivity $\mathrm{Cu}_{\mathrm{e}}$ (or $\mathrm{Cu}$ ) from 66.22 to $154.36 \mathrm{~kg} / \mathrm{m}^{2}$ (with a maximum in the Radlin 24 borehole). Cu-Ag mineralization is $1.75 \mathrm{~m}$ thick with the average of $2.29 \%$ $\mathrm{Cu}$ and $58 \mathrm{ppm} \mathrm{Ag}$ over an area of $264 \mathrm{~km}^{2}$. A resource of ca. $24 \mathrm{Mt}$ of $\mathrm{Cu}$ and approx. 55 thousand tons of Ag is estimated. In the central part of the area ore mineralization is at depths exceeding $3000 \mathrm{~m}$, but in the southern part it is at $2600-3000 \mathrm{~m}$.

Mozów: This area is adjacent to the northern Zielona Góra oxidized area. Initially, this area was defined by four drill holes made by PGNiG: Mozów 1, Kije 2, Kije 9 and Kije 10 [18], and then a reevaluation was made in this area [21,24]. Recently, MCC drilled two further boreholes (M C3, M C1), which confirmed the presence of very rich mineralization [46,105]. In all profiles, the oxidized interval includes the Weissliegend and the lowermost part of the Kupferschiefer (Figure 11). A chalcocite-digenite-covellite association prevails, occasionally with bornite. In oxidized parts hematite is abundant, accompanied by remnant covellite and digenite as well as native gold. Au-Pt-Pd mineralization occurs directly below the $\mathrm{Cu}-\mathrm{Ag}$ interval (Figure 12). Numerous copper sulfide nests are noteworthy in carbonates. The richest Kije 9 borehole has an extremely high $\mathrm{Cu}_{\mathrm{e}}$ productivity of $274 \mathrm{~kg} / \mathrm{m}^{2}$. Based on results from the six boreholes, it was estimated that this prospect, which covers $214 \mathrm{~km}^{2}$, may contain $30.3 \mathrm{Mt}$ of $\mathrm{Cu}$ and $55.905 \mathrm{kt}$ of Ag over a thickness of $2.09 \mathrm{~m}$, with an estimated grade of $2.71 \% \mathrm{Cu}$ and $50 \mathrm{ppm} \mathrm{Ag}$ at depths of 2100 to $2700 \mathrm{~m}$. On a regional scale, the Mozów area appears to extend to the SE to the Nowa Sól prospect. It should be noted that oxidized intervals are enriched in gold [46]. 


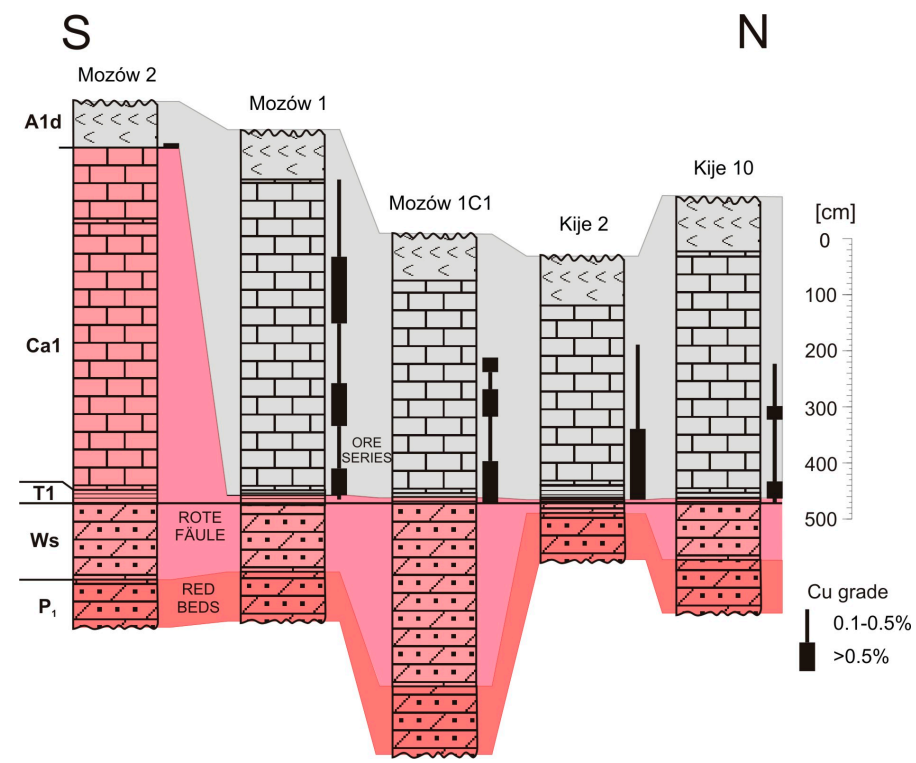

Figure 11. Relation of the ore series to the oxidation front; note the oxidation in the lowermost part of the Kupferschiefer in the Mozów prospect (for legend see Figure 4).

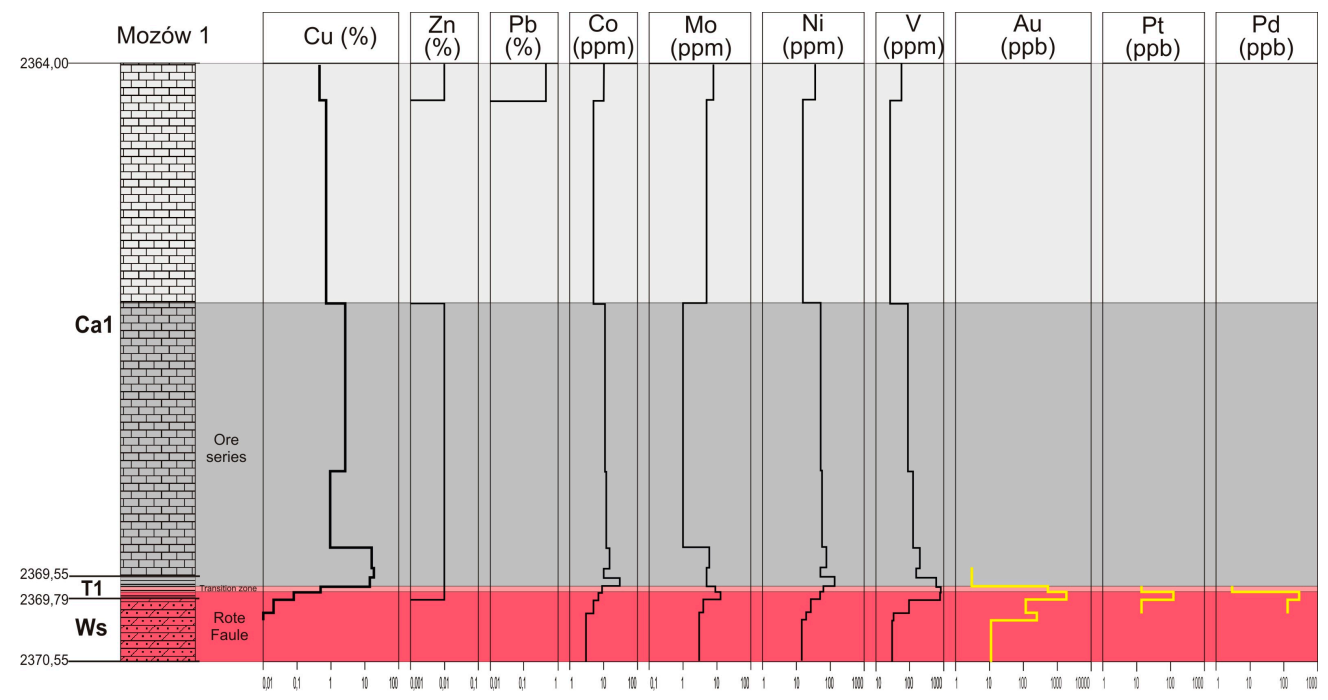

Figure 12. Antithetic distribution of base and precious metals in the Mozów 1 borehole.

\subsection{Speculative Resources of Low Potential}

In addition to the above-mentioned areas of high potential, 22 further prospective areas with lower potential were also identified (Figure 8; Table 8). Their boundaries are demarcated around only one borehole with productivity over $35 \mathrm{~kg} / \mathrm{m}^{2}$. Among them, the most important areas may be located in the immediate vicinity of oxidized fields and at shallow depths (Nowiny, Mirków and Żarków) but also at depths slightly greater, but not exceeding $2000 \mathrm{~m}$ (Bogdaj, Czeklin and Dębinka). Particular importance may be attributed to areas possibly connected to other prospective areas (e.g., Bogdaj, Naratów 3, Milicz and Wilcze).

Among them, the most important one due to its depth of 400-600 $\mathrm{m}$ is the Nowiny area, where shale ore was found above oxidized sandstones. Ore minerals are dominated by chalcocite, accompanied by bornite, covellite, sphalerite, galena and pyrite. The ore interval has a thickness of $0.47 \mathrm{~m}$ and is characterized by the average grade of $2.64 \% \mathrm{Cu}$ and $100 \mathrm{ppm} \mathrm{Ag}$ with productivity of $42.74 \mathrm{~kg} / \mathrm{m}^{2}$ $\mathrm{Cu}_{\mathrm{e}}$. Despite the small area $\left(5.72 \mathrm{~km}^{2}\right)$, it is realistic to envisage an orebody forming a $1-3 \mathrm{~km}$ wide belt. Its continuation in the western direction is likely, with a chance of merging with the 
Spremberg-Weisswasser deposits in Germany. Currently, this area is a subject of an exploration license of KGHM. Hopes can also be associated with the Debinka area, which is located at the edge of the oxidized area. Admittedly, $\mathrm{Cu}-\mathrm{Ag}$ mineralization in this area is confined solely to the upper part of the Zechstein Limestone [74,106], but there is a possibility that eastwards it can be also found in the Kupferschiefer and the Weissliegend. Taking into account proximity to the Szprotawa high, there is an expected extension of mineralization towards this elevation. A similar position, but on the northern side of this elevation, is occupied by the Żarków and Czeklin prospects. These areas form embayments in the Zielona Góra Rote Fäule area open to the south. The area of Bogdaj may be important in the case of its connection with the Henrykowice area, and Milicz area when it connects to the Janowo prospect. The area of Mirków is characterized by rich copper mineralization above the oxidized Basal Limestone. However, it is surrounded by boreholes in which Kupferschiefer series is characterized by lead-zinc mineralization. In turn, the significance of the Naratów 3 area can be considerable if it is connected to the Luboszyce prospect.

The remaining areas currently do not have any substantial importance as they are very small (Bartków, Lipowiec, Naratów 1 and Ślubów) or occur at significant depths (Broniszewice, Bukowiec, Florentyna, Niemierzyce, Paproć, Rogalin, Wilcze and Żakowo). Two other areas (Borzęcin and Radziądz) with polymetallic $(\mathrm{Cu}-\mathrm{Pb}-\mathrm{Zn})$ mineralization are located further from the redox boundary, so the chances of finding rich ore are not very high.

\section{Exploration Drilling}

Several companies have drilled on their granted concessions (Figure 8). The exploration drilling program of MCC, which started in 2013 and still continues today, has resulted in the discovery of three deposits: Nowa Sól, Mozów and Sulmierzyce North (Figure 13). The boundaries of prospecting concessions were established based on several criteria, most importantly the distance to the flanks of intra-basin ridges (Brandenburg-Wolsztyn-Pogorzela and Szprotawa highs) and the contacts between reduced rock facies and secondary oxidized Rote Fäule rocks (Figure 8). The areas with prognostic copper mineralization demarcated by the PGI-NRI [21] were also considered while determining the boundaries of targets. Although some of MCC's initial prospecting concessions, namely those located close to the existing Lubin-Sieroszowice mining district, had certain historical data on $\mathrm{Cu}-\mathrm{Ag}$ mineralization, the majority of targets constituted greenfield areas, distant from known ore deposits.

MCC's initial work included the analyses of drill core samples from historical oil and gas wells. Due to the nature of hydrocarbon exploration, these boreholes were not distributed in regular grids; instead, they form clusters of several to over a dozen holes. Such distribution does not correspond to the strategy of copper prospecting. In addition to core analyses, MCC carried out the reprocessing of archival geophysical data, which involved examining 24,000 gravimetric points and more than $1700 \mathrm{~km}$ of seismic sections. Seismic data was reprocessed using the innovative method of effective reflection coefficients to complement the drilling, providing much higher resolution compared to standard, amplitude-based seismic sections [107]. This method accurately determines structural elements crucial for exploration. Furthermore, in two of its targets (Mozów and Sulmierzyce) MCC performed experimental on-site geophysical research using the magnetotelluric method, with a total surveying length of $27 \mathrm{~km}$. The results of magnetotelluric studies were not accurate enough to trace the trends of copper mineralization at depths exceeding $1500 \mathrm{~m}$. For this reason it was decided to discontinue further use of this method. 

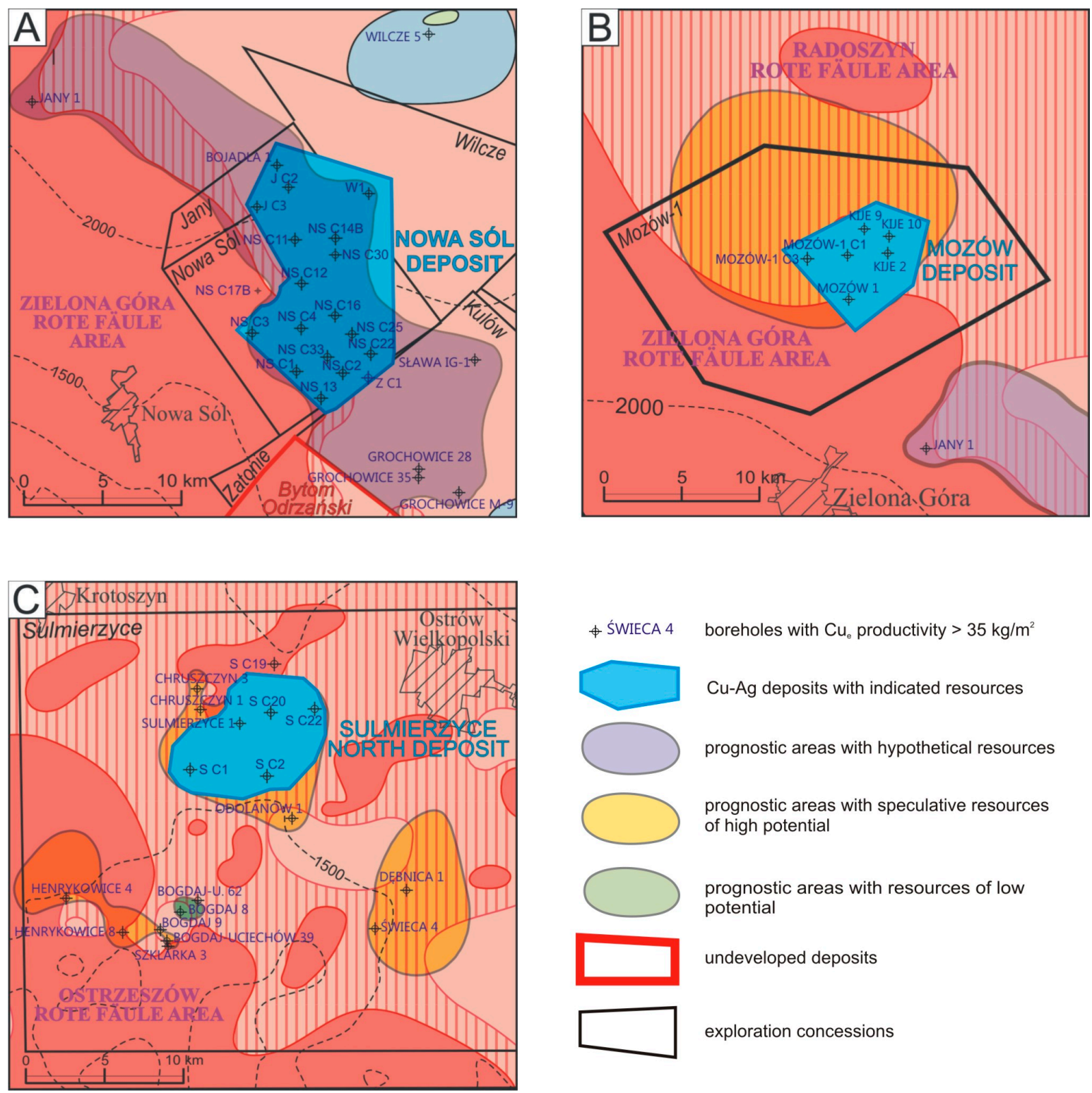

Figure 13. $\mathrm{Cu}-\mathrm{Ag}$ deposits recognized by the Miedzi Copper Corp. (MCC) within its concessions (for legend see Figure 8). (A) Nowa Sól deposit; (B) Mozów deposit and (C) Sulmierzyce North deposit.

Once all of the above mentioned research was completed, MCC commenced its own drilling stage. Core material from these new boreholes was also subjected to chemical analyses by Acme Analytical Laboratories Ltd., as well as petrographic and mineralogical studies. The initial drilling results led to considerable changes in the drilling grids, as the location of Rote Fäule zones was slightly shifted compared to earlier maps $[48,50]$. This was particularly noticeable in concessions with no historical oil and gas wells, like Nowa Sól, where the observed north-eastern extension of the oxidized zone was greater than expected. These conclusions were possible due to the combined interpretation of new drilling logs and seismic reprocessing, proving that the area is divided into fault blocks, which resulted in the north-eastern displacement of Rote Fäule facies.

Of the 33 holes completed in the years 2013-2019, 25 produced positive results in terms of economic $\mathrm{Cu}$-Ag grade. Moreover, all boreholes led to more precise identification of boundaries between major oxidized and reduced areas. Due to better understanding of the regional geological structure, certain prospecting targets were reduced in area after the initial drilling phase in order to focus on their 
richest, most prospective parts. Effectively, further drilling operations were continued in only six most promising targets (Nowa Sól, Wilcze, Zatonie, Jany, Mozów-1 and Sulmierzyce).

The three stratiform $\mathrm{Cu}-\mathrm{Ag}$ deposits identified by MCC in Poland-Nowa Sól, Mozów and Sulmierzyce North—lie within the boundaries of areas. Their location is presented in Figure 13.

The Nowa Sól deposit: This deposit partially overlaps four concession areas: Nowa Sól, Jany, Zatonie and Wilcze. At the Nowa Sól deposit, 18 boreholes have been drilled in two grids, $1.5 \mathrm{~km} \times 1.5 \mathrm{~km}$ and $3 \mathrm{~km} \times 3 \mathrm{~km}$ (Figure 13A). The depth of the mineralized horizon varies from 1700 to $2200 \mathrm{~m}$ below ground level. This deposit is an entirely new discovery, as there had been no historical

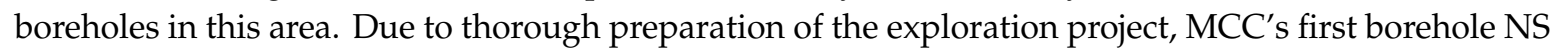
C1 already penetrated a thick interval with very high ore grade (productivity $281 \mathrm{~kg} / \mathrm{m}^{2}$ ).

In this deposit there are both reduced sections with sulfide mineralization in the eastern parts of the studied area, as well as oxidized (Rote Fäule) zones without sulfide mineralization of economic importance-in the western and south-western part of the Nowa Sól deposit. The redox boundary moves from the Lower Anhydrite in the west to lower parts of the Weissliegend in the east (Figure 9). In the most westerly-located NS C17B borehole, the entire ore series is oxidized from the Lower Anhydrite to lower parts of the Weissliegend sandstones. In boreholes Jany C1 and NS C3, the redox front crosses the Zechstein Limestone, and in profiles NS C1, NS C2, NS C4, NS C13 and NS C33 cuts across the lowermost part of the Kupferschiefer horizon.

Oxidized rocks contain relict copper mineralization (Figure 14A-F) in the form of remnant digenite, covellite, chalcocite and pyrite, partly replaced by iron oxides (hematite and minor goethite). Iron oxides occur in several forms, as pigment, pellets, clumps and mineral aggregates, irregular fine grains dispersed in the matrix, micro-inclusions in sulfides, and earthy masses of lenticular shapes. Complex intergrowths of hematite with digenite (Figure 14A), covellite and chalcocite are remarkable, as well as mutual intergrowths with native gold. Very often small amounts of very fine grained specular hematite form a halo around sulfides (Figure 14B). Textures of the sulfide minerals are characterized by uneven grain size expressed as macroscopically visible nest-textures, small xenomorphic inclusions and medium-sized composite grains (Figure 14C). Sulfide-hematite mineralization is accompanied by accessory minerals, such as: Native gold, silver amalgams, electrum (Figure 14D), auricuprite and selenodigenite. Hematite pseudomorphs after framboidal pyrite and other sulfide minerals are regularly found in the oxidized Kupferschiefer (Figure 14E). Textures of particular relevance for interpreting the origin include partial replacements of chalcocite (Figure 14F), covellite, digenite, bornite, chalcopyrite and pyrite by iron oxides and hydroxides, exhibiting evidence of reaction. Native gold is found in the form of intergrowths with electrum and commonly as inclusions in covellite and tiny crystals scattered in rock matrix (Figure 14D). The maximum gold, platinum and palladium contents reach several ppm Au and several hundred ppb Pt and Pd in the oxidized sandstones and shales, comparable to those found in the western areas of the Lubin-Sieroszowice deposit [76-78,80,81].

In the Nowa Sól deposit, Cu-S-type sulfides (chalcocite, digenite and covellite) are dominant, while Cu-Fe-S-type sulfides (bornite and chalcopyrite) are less abundant. Locally, copper minerals are accompanied by galena, sphalerite and pyrite, and the most common accessory minerals are: Tetrahedrite, native silver, silver amalgams, nickeline, cobaltite, rammelsbergite, stromeyerite and auricuprite. Both in the vertical and horizontal distribution the regularity of the Cu-S-sulfide predominance in the immediate vicinity of the redox border is noticeable (on its reduced side) and the coexistence of $\mathrm{Cu}-\mathrm{Fe}$-S-type sulfides over and around the $\mathrm{Cu}$-S zone associated with lead, zinc and iron sulfides further from the redox border (e.g., Wilcze W1). 

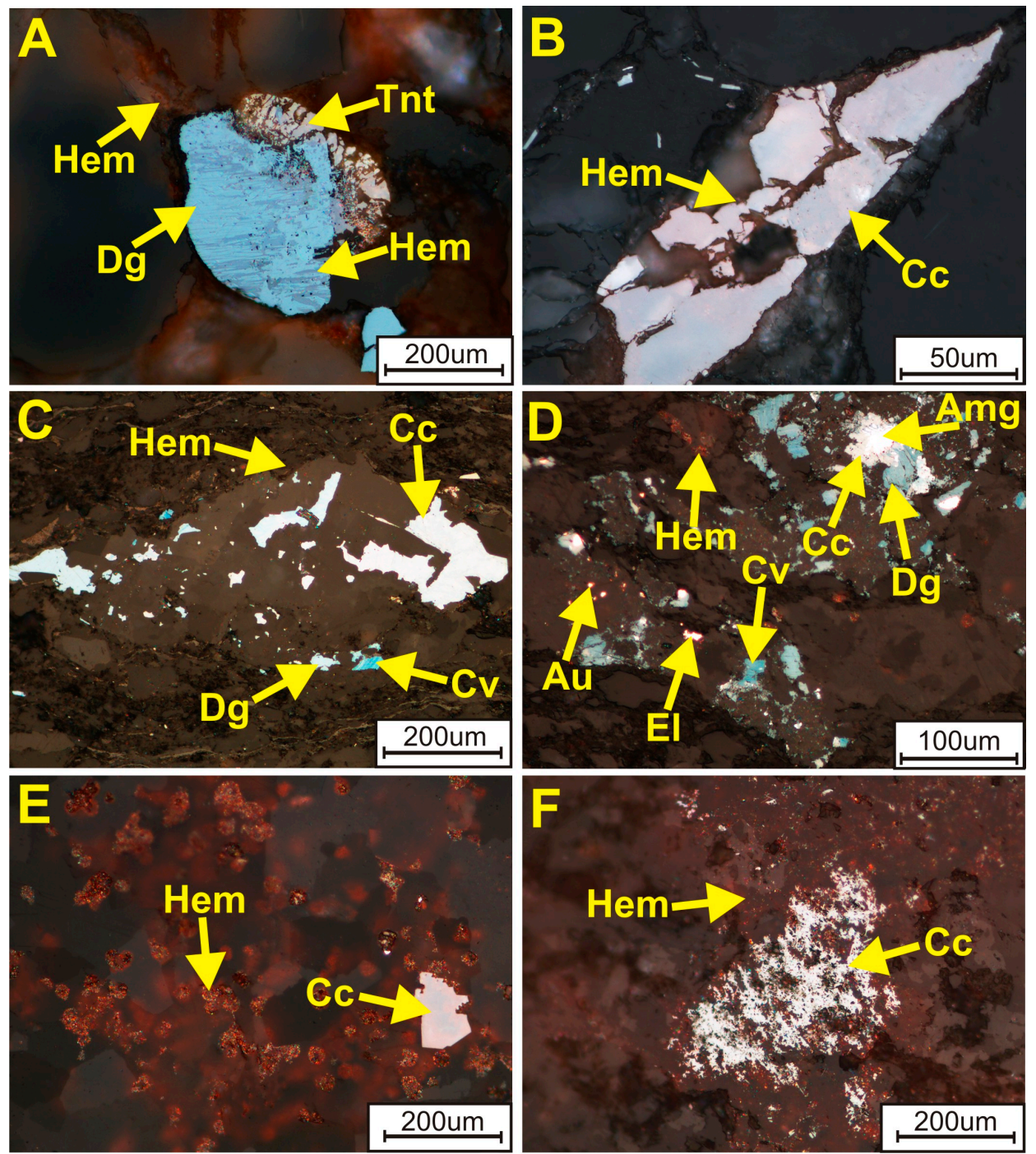

Figure 14. Photomicrographs of the sulfide-hematite mineralization in the Nowa Sól area (reflected light). (A) Digenite (Dg) invaded by hematite (Hem) laths and accompanied by degraded titanite (Tnt), Weissliegend, Nowa Sól C1 borehole. (B) Fractured chalcocite (Cc) with hematitic (Hem) halos, Weissliegend, Nowa Sól C2 borehole. (C) Remnants of chalcocite $(\mathrm{Cc})$, digenite $(\mathrm{Dg})$ and covellite $(\mathrm{Cv})$ in carbonate lens surrounded by oxidized dark matrix with hematite (Hem), Kupfesrchiefer, Nowa Sól C1 borehole. (D) Digenite (Dg), chalcocite (Cc) and covellite (Cv) sparsely disseminated in carbonate laminae, associated with silver amalgams (Amg), electrum (El), native gold (Au) and hematite (Hem), Kupferschiefer, Nowa Sól C3 borehole. (E) Remnant chalcocite (Cc) surrounded by hematite (Hem) pseudomorphs after framboidal pyrite, Zechstein Limestone, Nowa Sól C17B borehole. (F) Chalcocite (Cc) strongly degraded and corroded by hematite (Hem), Zechstein Limestone, Nowa Sól C3 borehole.

The ore series in the Nowa Sól deposit includes the sandstone, shale and carbonate ore. In the south-western part of the deposit, there is only carbonate ore (NS C3) or shale-carbonate ore (NS C1, NS C2, NS C4, NS C13 and NS C33) over the oxidized intervals, while in the central and eastern part of this deposit all types of ore are present (Figure 13A).

Sandstone ore was found in 13 boreholes, with the exception of the following: NS C1, NS C3, NS C4, NS C13, C17B and NS C33, in which the Weissliegend is oxidized. In the NS C2 borehole, in spite of the oxidized nature of the Weissliegend, there is thin upper sandstone ore. The thickness of this ore in the entire area varies considerably from $9 \mathrm{~cm}$ in the Jany C3 borehole, to $4.53 \mathrm{~m}$ in the Wilcze W1 borehole (the thickness of the entire white sandstone varies from $1.37 \mathrm{~m}$ in the NS C13 hole to $16.41 \mathrm{~m}$ in the NS C16 borehole). The average thickness of the sandstone ore is $1.75 \mathrm{~m}$. In the sandstone ore, 
the highest concentrations of copper minerals usually occur in the Weissliegend in contact with the Kupferschiefer, where they replace carbonates forming secondary cement. Locally, ore minerals replace detrital grains. The sandstone ore is dominated by chalcocite, which is accompanied by digenite and covellite, whereas the $\mathrm{Cu}-\mathrm{Fe}-\mathrm{S}$ sulfides are not present. The most common mineral assemblages include: Chalcocite with digenite and covellite (Figure 15A,B) and minor bornite. Associated minerals include: Galena, sphalerite, tennantite, rammelsbergite, silver amalgams (Figure 15B), native silver and, sporadically, lautite. Large intergrowths of chalcocite with digenite and bornite are common, just as composites of bornite, chalcopyrite, digenite and covellite.
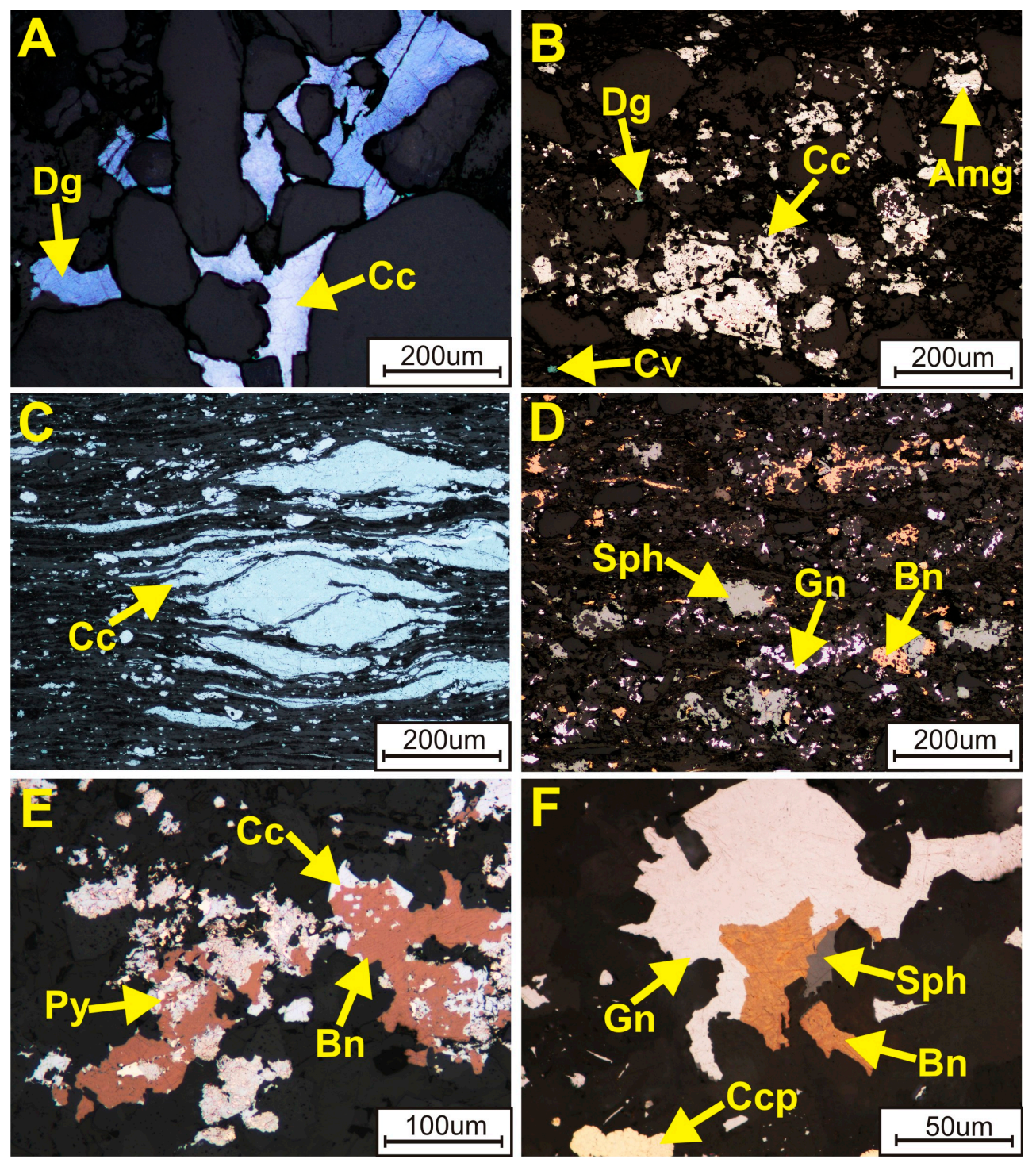

Figure 15. Photomicrographs of ore mineralization in the Nowa Sól area (reflected light). (A) Chalcocite (Cc) and digenite (Dg) interstitial to detrital grains, Weissliegend, Nowa Sól C16 borehole. (B) Chalcocite (Cc) disseminated in sandstone cement accompanied by tiny digenite (Dg), covellite (Cv) and silver amalgams (Amg), Weissliegend, Nowa Sól C2 borehole. (C) Replacements of carbonate lenses by chalcocite (Cc), Kupferschiefer, Nowa Sól C12 borehole. (D) Sphalerite (Sph), galena (Gn) and bornite (Bn) dispersed in shale, Kupferschiefer, Nowa Sól C2 borehole. (E) Chalcocite (Cc)-bornite (Bn) composites accompanied by pyrite (Py), Zechstein Limestone, Nowa Sól 16 borehole. (F) Aggregate of galena $(\mathrm{Gn})$, bornite $(\mathrm{Bn})$ and sphalerite $(\mathrm{Sph})$ in association with chalcopyrite $(\mathrm{Ccp})$, Zechstein Limestone, Nowa Sól 3 borehole. 
Shale ore occurs in 15 boreholes, but is absent in NS C16, due to the lack of Kupferschiefer, as well as in NS C3, where the Kupferschiefer is oxidized. The thickness of the shale ore varies slightly from $4 \mathrm{~cm}$ to $0.59 \mathrm{~m}$, and the average thickness of the shale ore is $0.22 \mathrm{~m}$. Shale ore in the western part of the Nowa Sól deposit contains associations strongly dominated by chalcocite (Figure 15C) and digenite, which are accompanied by covellite and locally bornite, but in the eastern part is dominated by bornite-chalcocite with sphalerite-galena assemblages (Figure 15D) and chalcopyrite-bornite. There are numerous accessory minerals in the form of small inclusions in other ore minerals: Native silver, silver amalgams, auricuprite, seleno-digenite, cobaltite, nickeline, acanthite and stromeyerite. Sulfides occur principally as fine disseminations, but also as coarse grains and scattered blebs, large irregular aggregates, complex composites, flat lenses and nests. Cu sulfides pseudomorphic after framboidal pyrite are common. Ore veinlets of various thicknesses, consistent with or diagonal to shale lamination were locally present.

Carbonate ore was found in 14 boreholes, and it is absent only in boreholes situated in the eastern and northern parts of the Nowa Sól deposit (NS C22, Wilcze W1, Jany C3). In the vast majority, carbonate ore occurs in the lower part of the Zechstein Limestone, but in the NS C3 hole it occupies a position over the oxidized part of the lower Zechstein Limestone. The thickness of the carbonate ore varies considerably from $0.21 \mathrm{~m}$ (NS C30) to $3.92 \mathrm{~m}$ (NS C4), while the thickness of the Zechstein Limestone varies between 1.73 and $6.19 \mathrm{~m}$. The average thickness of the carbonate ore is $1.58 \mathrm{~m}$. The most common complex intergrowths of chalcocite, bornite and pyrite displaying replacement textures (Figure 15E) occur in the western part of this deposit, while galena-sphalerite-bornite-chalcopyrite-pyrite assemblage prevails in the eastern part (Figure 15F). These principal sulfides are accompanied by silver amalgams, native silver and tetrahedrite. Ore minerals occur as finely disseminated grains impregnating carbonates, usually concordant with lamination, and as coarse-grained aggregates, composites, nests, open-space filling and also veinlets. Above the ore horizon, low-grade mineralization is composed of galena, sphalerite and pyrite with minor bornite, chalcopyrite, chalcocite, digenite, covellite and silver amalgams.

At the current stage of the Nowa Sól deposit, the indicated resources (calculated in Polish categories $\mathrm{C}_{1}+\mathrm{C}_{2}$ ) amount to $10.6 \mathrm{Mt} \mathrm{Cu}$ and $36.4 \mathrm{kt} \mathrm{Ag}$, at an average thickness of $2.69 \mathrm{~m}$ and $2.03 \%$ copper.

According to the technical report and pre-feasibility study prepared for MCC by RungePincockMinarco [108], mining operations in this area are profitable from an economic point of view. The estimated production costs are US $\$ 2670$ per ton Cu with underground milling or US \$2698 with conventional milling. Geological documentation of the Nowa Sól deposit fulfilling the requirements of Polish law was presented to the Minister of Environment in August 2019. After the Minister's approval it will serve as a basis for a mining license.

The Mozów deposit: This deposit is delineated by four previously studied boreholes (Mozów 1, Kije2, Kije 9 and Kije 10) and two new MCC boreholes (Mozów-1 C1 and Mozów-1 C3; Figure 13B). The mineralized horizon is at depths from 2100 to $2400 \mathrm{~m}$ below ground level. This area is characterized by its very specific distribution of ore in the vertical profile. The bottom part of the Kupferschiefer and the Weissliegend are oxidized (Figures 11 and 12). Therefore, the mineralized interval starts in the middle or top Kupferschiefer and covers several meters of the Zechstein Limestone.

In the oxidized Weissliegend and the uppermost part of the Kupferschiefer there are only remnants of chalcocite and digenite (Figure 16A,B) partially replaced by hematite. In the transition zone of the Mozów-1 C1 and Mozów-1 C3 boreholes, native copper, gold, silver, electrum and bismuth along with silver amalgams, stromeyerite and $\mathrm{Cu}$-selenide sulfides have been detected [46,105]. 

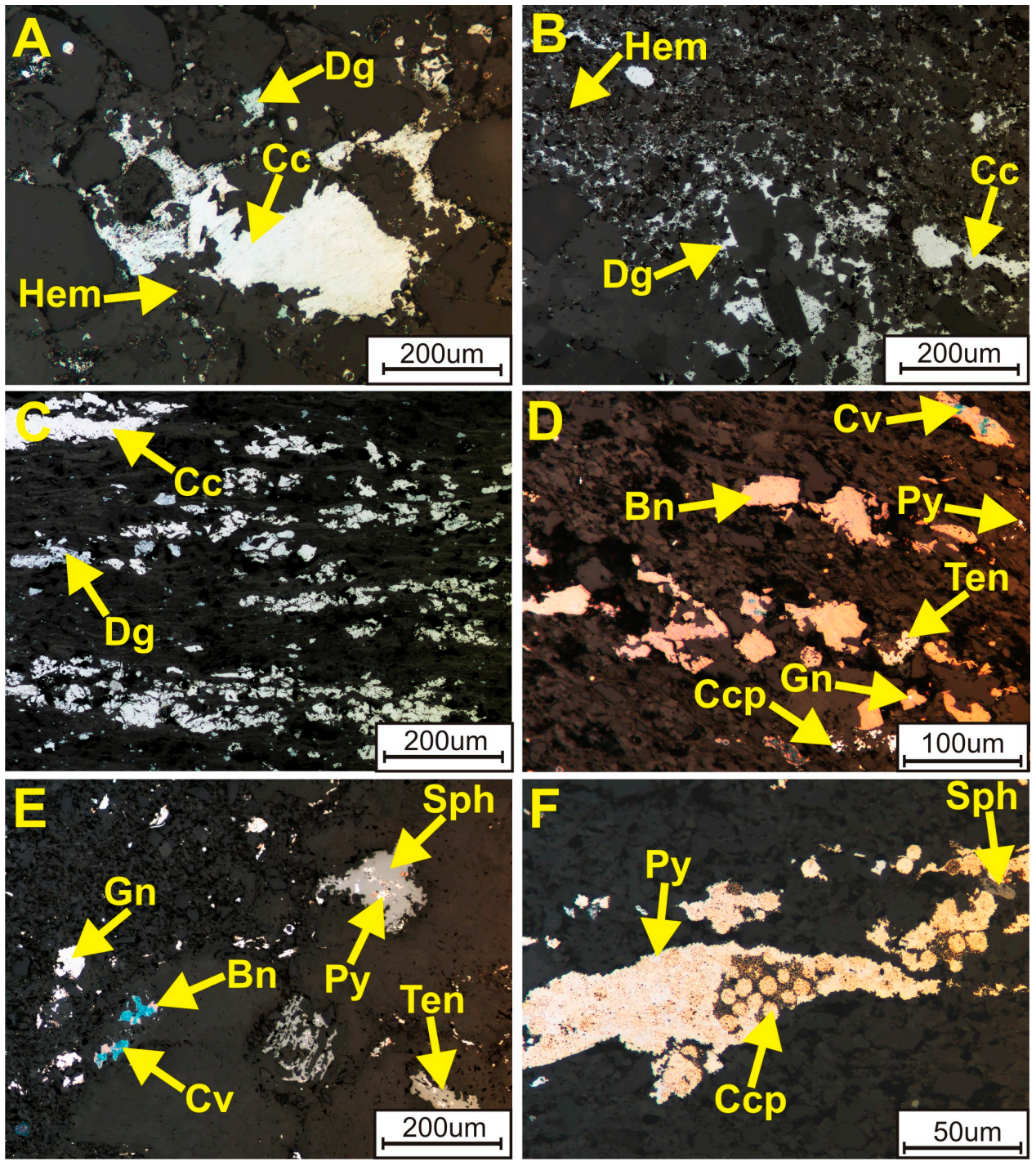

Figure 16. Photomicrographs of the ore mineralization in the Mozów area (reflected light). (A) Chalcocite (Cc) and digenite (Dg) accompanied by hematite (Hem), Weissliegend, Mozów 1 C3 borehole. (B) Chalcocite $(\mathrm{Cc})$ and digenite $(\mathrm{Dg})$ interstitial to detrital grains, associated with hematite (Hem), Weissliegend, Mozów 2 C1 borehole. (C) Chalcocite (Cc) and digenite (Dg) disseminated in shale, Kupferschiefer, Mozów 1 C3 borehole. (D) Bornite (Bn) accompanied by covellite (Cv) and tennantite (Ten), associated with pyrite (Py), Zechstein Limestone, Mozów 1C3 borehole. (E) Galena (Gn), bornite $(\mathrm{Bn})$, covellite $(\mathrm{Cv})$, pyrite (Py), sphalerite (Sph) and tennantite (Ten) dispersed in carbonates, Zechstein Limestone, Mozów 1 C3 borehole. (F) Replacements of pyrite (Py) framboids by chalcopyrite (Ccp) in association with sphalerite (Sph), Zechstein Limestone, Mozów 1 C3 borehole.

Carbonate-shale ore in the Mozów deposit is dominated by chalcocite that is accompanied by digenite (Figure 16C), and covellite, and subordinately by bornite, chalcopyrite, tennantite, galena and pyrite (Figure 16D). In the upper mineralized zone, galena, sphalerite and Cu-Fe-S-type sulfides are common (Figure 16E). Ore mineralization is complex both in terms of the composition and form of minerals. In the upper carbonate ore chalcopyrite predominates over sphalerite and pyrite, and commonly replaces framboidal pyrite (Figure 16F). Typically, in shale ore sulfides occur as fine disseminations, whereas in carbonate ore as coarse aggregates, lenses and nests. Sulfide replacements of carbonates as well as microfauna are common.

In spite of the considerable vertical range of Rote Fäule, ore grades can be very high, e.g., in MCC's Mozów-1 C1 borehole copper productivity amounts to $133 \mathrm{~kg} / \mathrm{m}^{2}$. Currently, the indicated 
resources (category $\mathrm{C}_{2}$ ) are $4.4 \mathrm{Mt} \mathrm{Cu}$ and $7.3 \mathrm{kt} \mathrm{Ag}$ at $2.42 \% \mathrm{Cu}$ in an average interval of $2.45 \mathrm{~m}$. Additional inferred resources estimated by MCC (Polish category $\mathrm{D}_{1}$ ) are $8.4 \mathrm{Mt} \mathrm{Cu}$ and $11.9 \mathrm{kt} \mathrm{Ag}$. Despite the depth, according to the technical report and pre-feasibility-study [108], mining operations would be economically feasible. The estimated production costs are US \$2705 per ton of copper with underground milling or US \$2765 per ton with conventional milling. All calculations for this and the following deposits are based on an expected average copper price of US \$3 per $1 \mathrm{lb}$ in a 10-year period.

As the prospective areas indicate, it is possible to combine the Nowa Sól and Mozów deposits, which probably form one copper belt extending presumably southward towards the Bytom Odrzański deposit.

The Sulmierzyce North deposit: This deposit has been outlined in the northern part of the Sulmierzyce prospective area that is a part of the much larger Sulmierzyce concession (Figure 13C). It is intersected by Sulmierzyce 1 (first studied borehole) and four MCC new boreholes (Sulmierzyce $\mathrm{C} 1, \mathrm{C} 2, \mathrm{C} 20$ and C22). The depth of the mineralized zone ranges between 1400 and $2000 \mathrm{~m}$ below ground level.

There is virtually no mineralization in Weissliegend, as this unit is almost entirely oxidized in the whole area. Moreover, in several boreholes (Sulmierzyce 1, C2 and C20) the lowermost part of the Kupferschiefer also displays oxidation. Oxidized rocks contain remnants of covellite, digenite and bornite partly replaced by iron oxides. Hematite pseudomorphs after pyrite framboids are common in oxidized shales. Therefore only carbonate-shale ore occurs here. In spite of this, five boreholes demarcating this deposit (e.g., Sulmierzyce C20 productivity of $241 \mathrm{~kg} / \mathrm{m}^{2}$ ) have very high grade ore in an interval comprising the Kupferschiefer and the Zechstein Limestone (Figure 10).

The mineral assemblage consists of $\mathrm{Cu}-\mathrm{S}$ and $\mathrm{Cu}$-Fe-S-type sulfides (Figure 17A-F). Fine disseminations prevail (Figure 17A,B) but aggregates, lenses and nests are also common (Figure 17C-F). In the northern part of this deposit mineralization is dominated by a bornite-chalcocite association (Figure 17A), with minor digenite and covellite, as well as rare sphalerite and tennantite, whereas the southern part has bornite-digenite (Figure 17B) mineralization accompanied by galena and chalcopyrite (Figure 17C). Chalcopyrite is very often replaced by bornite and covellite (Figure 17C). There are remarkable replacements of carbonate and detrital grains (Figure 17D), as well as chalcocite, digenite, bornite and galena pseudomorphs after pyrite framboids, and the pyrite framboids cemented by bornite or galena. Overgrowths of bornite and covellite with sphalerite accompanied with minor pyrite are very common (Figure 17E). In the upper parts of the carbonate ore there are numerous polymineral aggregates composed of bornite, sphalerite, chalcopyrite, covellite, tennantite and pyrite (Figure 17F).

The indicated resources of the Sulmierzyce North deposit (in Polish categories $\mathrm{C}_{1}+\mathrm{C}_{2}$ ) are estimated at 7.2 Mt Cu and $15.2 \mathrm{kt} \mathrm{Ag}$, with an average thickness of $1.87 \mathrm{~m}$ at $2.93 \% \mathrm{Cu}$. According to the technical report and pre-feasibility study of RungePincockMinarco [109], future mining operations are also economically justified. The expected production costs are US \$2429 per ton of copper. Geological documentation of this deposit is in preparation and it will be conveyed to the Minister of Environment in 2019. It is also possible to calculate the value of mineral resources including zinc and lead [110].

The Sulmierzyce concession area is characterized by a patchy distribution of mineralization, which makes tracing its boundaries complicated. The patchy, island-like nature of the Sulmierzyce deposit is somewhat similar to the southern parts of the Polkowice mining area, and strongly differs from the Rudna mine, where the vast majority of mineralization occurs in the Weissliegend. 

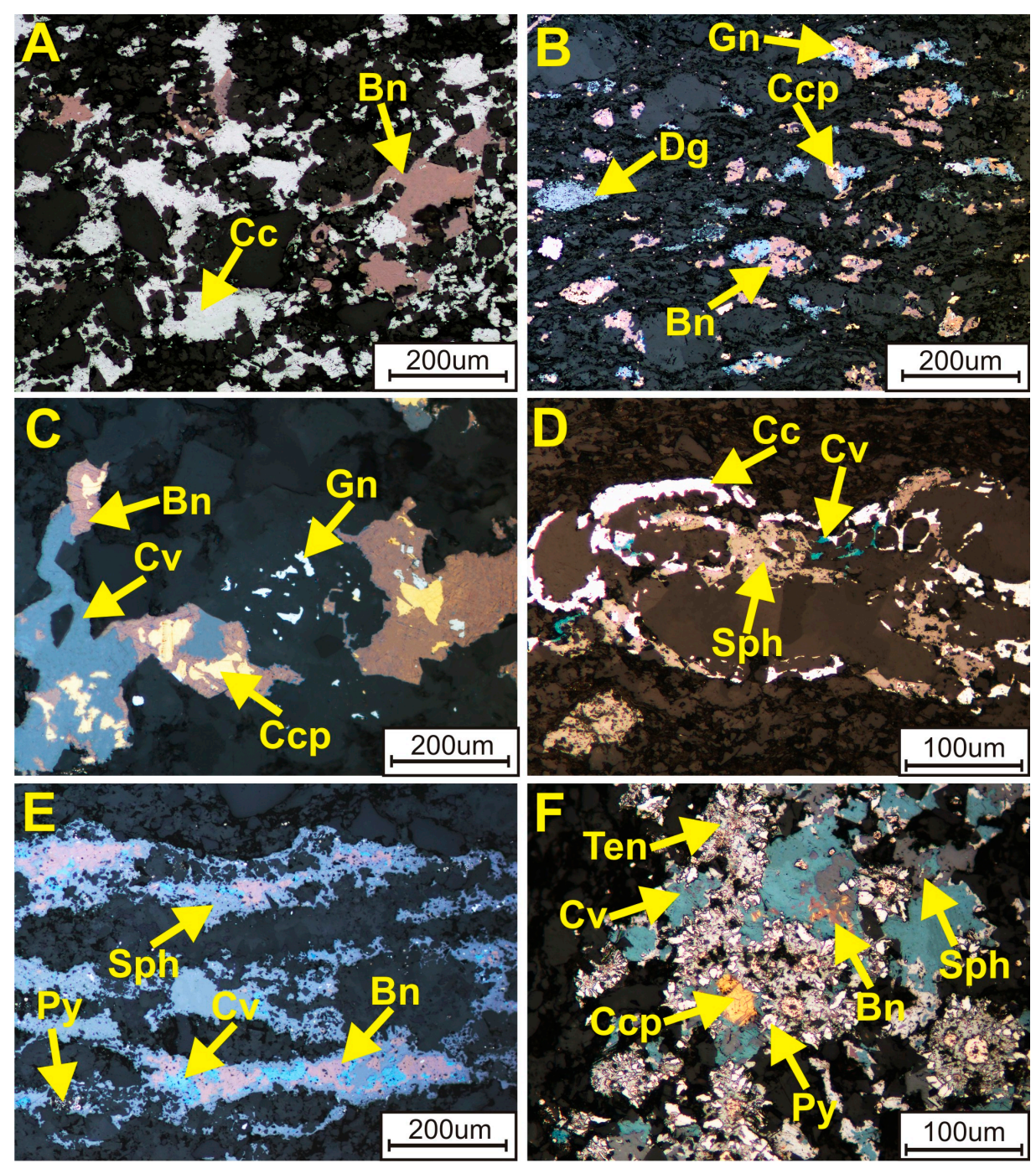

Figure 17. Photomicrographs of the ore mineralization in the Sulmierzyce area (reflected light). (A) Rich chalcocite $(\mathrm{Cc})$-bornite $(\mathrm{Bn})$ mineralization, replacing and cementing carbonate grains, Kupferschiefer, Sulmierzyce C 20 borehole. (B) Bornite (Bn) and digenite (Dg) with minor chalcopyrite (ccp) and galena (Gn), replacing carbonate lenses in shale, Kupferschiefer, Sulmierzyce C2 borehole. (C) Complex replacement of chalcopyrite $(\mathrm{Ccp})$ by bornite $(\mathrm{Bn})$ and covellite $(\mathrm{Cv})$, associated with galena $(\mathrm{Gn})$, Zechstein Limestone, Sulmierzyce C2 borehole. (D) Chalcocite (Cc), covellite (Cv) and sphalerite (Sph) replacing skeletal grains, Zechstein Limestone, Sulmierzyce C1 borehole. (E) Streaks composed of bornite (Bn), covellite (Cv), sphalerite (Sph) and minor pyrite (Py), Zechstein Limestone, Sulmierzyce $\mathrm{C} 1$ borehole. (F) Complex aggregate composed of covellite (Cv), chalcopyrite (Ccp), pyrite (Py), bornite (Bn), sphalerite (Sph) and tennantite (Ten), Zechstein Limestone, Sulmierzyce C1 borehole.

\section{The Future of Polish Copper}

The latest studies of numerous drillhole cores strongly indicate that the Kupferschiefer series contains a very large volume of prospective resources outside the Lubin-Sieroszowice Copper District. Until the end of the last decade, 17 prospects with the ore zones at depths up to $2000 \mathrm{~m}$ were delineated [21]. Areas with prospective resources (Kulów and Luboszyce), adjacent to the Zielona Góra oxidized area and to the documented Lubin-Sieroszowice deposit, deserved particular attention. The Nowiny, Żarków and Mirków areas also became interesting due to accessible depths, along with the Mozów area (including the Jany subarea) - because of high-grade mineralization, as well as the Sulmierzyce area - due to its considerable prospective resources and reasonable depth. Therefore, all of these areas have been covered by exploration concessions that were granted to MCC and other 
companies [24,30]. Within all concession areas MCC is continuing its exploration projects. Due to MCC's new boreholes (18 in the previously unexplored Nowa Sól area, two in the Mozów area and six in the Sulmierzyce area), new boundaries of the Jany-Nowa Sól-Grochowice, Mozów and Sulmierzyce prospects have been delineated (Figure 13).

Currently 35 prospective areas have been delineated throughout SW Poland (Figure 8). Potential resources in SW Poland (including results obtained by MCC) are estimated to be approximately $165 \mathrm{Mt}$ $\mathrm{Cu}$ and $398 \mathrm{kt} \mathrm{Ag}$ (Table 8), with a significant proportion of them occurring at large depths over $2000 \mathrm{~m}$. Future exploration, development and mining extraction of these prospective resources will be possible when geological and technological barriers (depth, temperature, oil and gas) meet economic trends in the world market $[24,43,45,50]$.

Extensive deep exploration drilling programs by MCC and other companies are currently implemented to verify the resource potential (Figure 8). Out of the three $\mathrm{Cu}-\mathrm{Ag}$ deposits newly discovered by MCC (Figure 13), Nowa Sól is the first one to achieve geological documentation. According to the Polish law, an investor who has documented a deposit in a minimum category of $C_{1}$ can apply for a mining license. After submitting the initial documentation of Nowa Sól in August 2019, MCC plans to continue its drilling operations there. This will enable an increase in the resources and the area of this deposit. The results of additional work will be reported in an annex to the documentation, which will be finalized and conveyed to the Ministry of Environment in early 2021. A mining license in Poland is usually issued for approximately 30 years, with a possibility of future extension. This means that a new copper mine can be constructed in the mid-2020s. It will operate concurrently with the existing mines of the Lubin-Sieroszowice Mining District, whose estimated total resources ensure continuous production for the next 50 to 60 years.

The area above the Nowa Sól deposit consists in $70 \%$ of forests. In order to minimize the environmental impact of the conducted activities, the investor has prepared plans for an underground ore processing plant. This will allow the reduction of area occupied by aboveground infrastructure and lower the hoisting costs. The copper concentrate will be pumped to the surface, while most of the tailings will be used underground to produce paste backfill [108,111]. The paste backfill technology was first introduced in Germany as early as the 1980s and is currently used in several large mines worldwide. Paste backfill is a pumpable, flowable, non-Newtonian fluid consisting of mine tailings and cement. It is prepared from dilute slurries of tailings by dewatering with conventional thickening or filtering. Its use for the protection of mining headings results in a reduced need for mine dewatering, labor and materials savings, lower tailings impoundment requirements, good support properties and reduced spills underground [112-114].

The temperature of rocks in the new mines can be as high as 50 to $60^{\circ} \mathrm{C}$. This problem will be alleviated by the use of another modern technology, which involves the cooling of mining headings by ice. It will be generated in a plant below the ground surface and transported to the working area as ice slurry. This solution will allow access of workers to deep headings, and operating costs will also be lower than in a mine cooled with water. For an identical cooling capacity, the required volume of ice is five to six times lower compared to water [115]. The use of ice as a coolant enables the construction of deeper mines, while the pumping costs and the size of cooling machinery are reduced [116].

In order to improve the economic results predicted by the pre-feasibility studies [108,109], the investor is planning to recover additional valuable elements from ore, e.g., $\mathrm{Pb}$ and $\mathrm{Zn}$ (Figure 18). The primary examples are lead, rhenium and nickel, already produced in the existing mining district, and cobalt, which would be a new by-product for the Polish copper industry. Other components may include rare earth elements, gold and PGE. Due to the size of the mine face, rocks of small thickness below and above the copper-bearing series will also be extracted and subject to ore processing. These rocks host valuable minerals, including noble metals. In the future, when the working face advances to areas of a more polymetallic nature (e.g., the eastern part of Nowa Sól), production of several concentrates will be considered-separately for copper and other metals. 


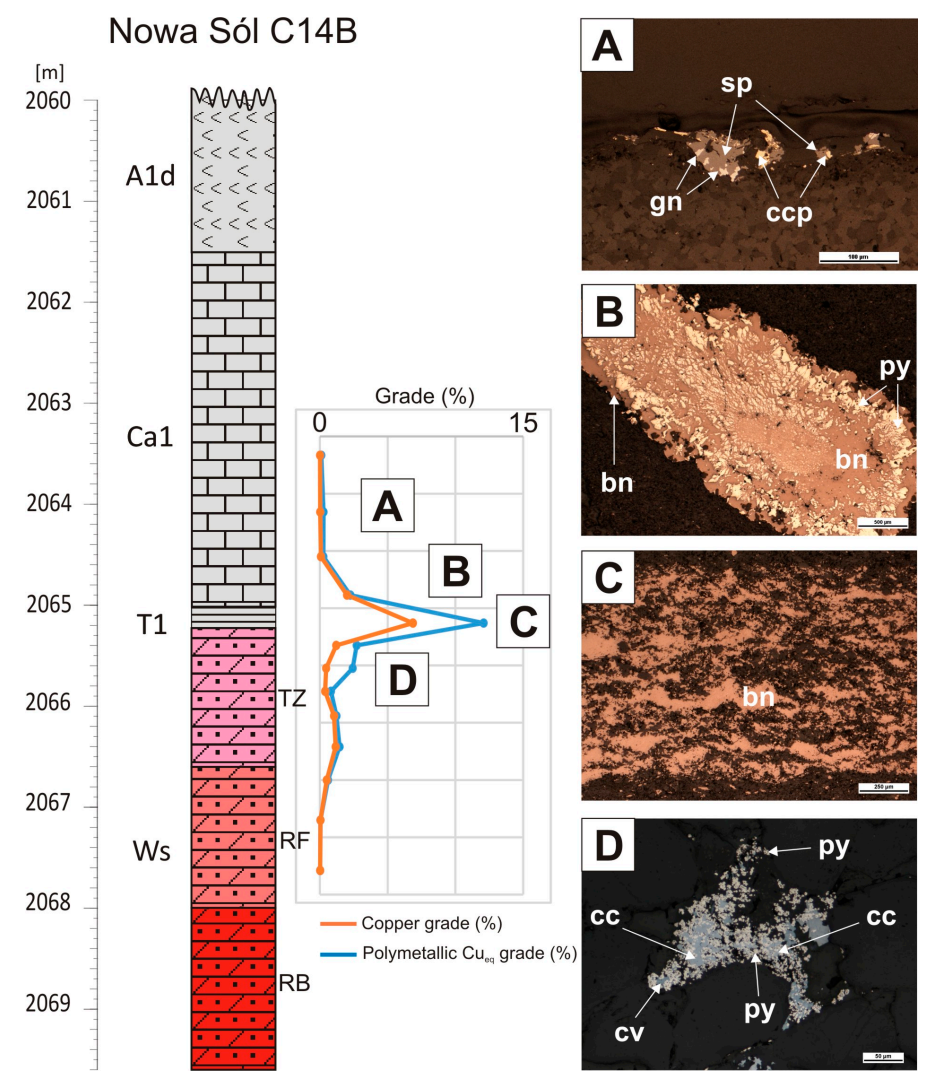

Figure 18. Lower Zechstein profile from the Nowa Sól C14B borehole with results of chemical analysis and ore mineralogy. Orange line represents copper grade, blue line represents polymetallic copper equivalent grade $(\mathrm{Cu}+\mathrm{Ag}+\mathrm{Pb}+\mathrm{Zn})$ calculated using the formula of Zieliński and Wierchowiec [108]. A1d-Lower Anhydrite; Ca1-Zechstein Limestone (A,B); T1-Kupferschiefer (C); Ws-Weissliegend (D); RB—red beds; RF—Rote Fäule; TZ—transition zone; sp—sphalerite; gn—galena; ccp—chalcopyrite; py—pyrite; bn—bornite; cc—chalcocite; cv—covellite.

Technical plans for future mines assume the use of modern electric machinery for cutting and transporting the ore. Most of the machines will be unmanned and controlled remotely. The smaller number of people working at the face will be compensated for by more workers supervising the remote control system. The ongoing technological progress also allows increasing the production rate due to the use of more efficient underground equipment $[42,117]$.

As mentioned earlier, the Minister of the Environment has established threshold parameters defining mineral deposits and their boundaries (Table 3). Those values are however somewhat obsolete, as they do not take into consideration the above mentioned new technological solutions and continuous advancements in the mining industry. As a result, the assumed maximum depth of a stratiform copper ore deposit is $1500 \mathrm{~m}$ below ground level. This would theoretically mean that none of the three above-mentioned new deposits fulfill these criteria due to their depths. Fortunately and rightfully, the Minister's regulation on the matter allows the use of customized parameters, which can be introduced in cases of "exceptional geological conditions".

Considering the above, MCC had to develop its own criteria, hereinafter called the "investor's parameters". The primary objective of such parameters is to ensure economically feasible extraction and processing of ore. Therefore, their selection was based on the pre-feasibility studies prepared by RungePincockMinarco/RPM Global USA Inc., a world-renowned expert on the construction of deep mines $[108,109,118]$. Taking into account modern technologies and economic analysis, new "investors parameters" were established, as presented in Table 9. 
Table 9. "Investor's parameters"- threshold values of parameters defining a sediment-hosted stratabound copper deposit and its boundaries used by MCC.

\begin{tabular}{ccc}
\hline Parameter & Unit & Threshold \\
\hline Maximum depth of the ore deposit & $\mathrm{m}$ & 2400 \\
Minimum Cu grade in a sample delimiting the ore deposit & $\%$ & 0.3 \\
Minimum Cu equivalent grade taking into account the silver content $(\mathrm{Ag})$ in the & $\%$ & 0.5 \\
profile of the deposit along with gangue interlayers Cu $=(\% \mathrm{Cu})+0.01(\mathrm{~g} / \mathrm{t} \mathrm{Ag})$ & & 50 \\
Minimum Cu equivalent productivity of the ore deposit at depths of $\leq 1900 \mathrm{~m}$ & $\mathrm{~kg} / \mathrm{m}^{2}$ & 60 \\
Minimum Cu equivalent productivity of the ore deposit at depths of $1900-2400 \mathrm{~m}$ & $\mathrm{~kg} / \mathrm{m}^{2}$ & 60 \\
\hline
\end{tabular}

The maximum depth investigated in the pre-feasibility studies in terms of the economic and technical possibilities of mining extraction was $2400 \mathrm{~m}$, which is why it constitutes one of the investor's parameters. However, deeper deposits could be subject to a similar analysis in the future. According to Goodell et al. [108], the operating costs of extraction at $2400 \mathrm{~m}$ will only be $1 \%$ higher compared to a depth of $1900 \mathrm{~m}$ (US $\$ 39.92$ and 39.51 per 1 metric ton of ore, respectively). Nonetheless, a higher required $\mathrm{Cu}_{\mathrm{e}}$ value has been used for deposits deeper than $1900 \mathrm{~m}$ to compensate for additional costs of air conditioning, etc., which will be higher in deeper mines. The overall increase in minimum $\mathrm{Cu}_{\mathrm{e}}$ compared to state parameters is caused by the necessity to focus on higher quality of ore relative to shallow deposits.

Reduction of the minimum copper grade $(\mathrm{Cu})$ in a sample delimiting the ore deposit will have no significant impact on the feasibility of extraction, as this value is of secondary importance to $\mathrm{Cu}_{\mathrm{e}}$. However, the value of $0.3 \%$ makes it possible to include in the deposit's resources its top and bottom parts, which are usually extracted anyway due to the dimensions of mining machinery. It should be also pointed out that the minimum weighted average copper equivalent grade parameter remains unchanged compared to Table 3. The investor's parameters were used to establish the boundaries and calculate the resources of the Nowa Sól, the Mozów and the Sulmierzyce North deposits, as specified in the previous chapter of the present paper.

Expected progress in underground mining at depths exceeding $1500 \mathrm{~m}$ will make this approach effective and technically possible.

Author Contributions: Cconceptualization, S.O., S.S.; methodology, S.O., K.Z.; investigation, S.O., A.C.; resources, S.O., S.S.; writing—original draft preparation, S.O., K.Z., A.C.; writing—review and editing, S.O., K.Z., A.C., S.S.; visualization, S.O., A.C., K.Z.; funding acquisition, S.S.

Funding: This work was partly supported by the statutory funds of the PGI-NRI (grant No. 61-6505-1501-00-0 to S.O. and A.C.).

Acknowledgments: We thank editors of Special Issue "Mineral Deposits of Central Europe", and two anonymous reviewers whose comments and suggestions greatly contributed to improving the paper. We are grateful to the Miedzi Copper Corp. for sharing the results of its exploration project in south-western Poland. Extended thanks are expressed to the Polish Oil and Gas Company for granting access to the cores.

Conflicts of Interest: The authors declare no conflict of interest.

\section{References}

1. Mudd, G.M.; Jowitt, S.M. Growing global copper resources, reserves and production: Discovery is not the only control on supply. Econ. Geol. 2018, 113, 1235-1267. [CrossRef]

2. Meinert, L.D.; Robinson, G.R.; Nassar, N.T. Mineral resources: Reserves, peak production and the future. Resources 2016, 5, 14. [CrossRef]

3. Singer, D.A. Future copper resources. Ore Geol. Rev. 2017, 86, 271-279. [CrossRef]

4. USGS. Mineral Commodity Summaries 2018; U.S. Geological Survey: Reston, VA, USA, 2018; p. 200.

5. Sverdrup, H.U.; Ragnarsdottir, K.V.; Koca, D. On modelling the global copper mining rates, market supply, copper price and the end of copper reserves. Res. Conserv. Recycl. 2014, 87, 158-174. [CrossRef]

6. Gustafson, L.B.; Williams, N. Sediment-hosted stratiform deposits of copper, lead, and zinc. Econ. Geol. 75th Anniv. Vol. 1981, 139-178. 
7. Kirkham, R.V. Distribution, setting and genesis of sediment-hosted stratiform copper deposits. In Sediment-Hosted Stratiform Copper Deposits; Geological Association of Canada Special Paper 36; Boyle, R.W., Brown, A.C., Jowett, E.C., Kirkham, R.V., Eds.; Geological Association of Canada: Ottawa, ON, Canada, 1989; pp. 3-38.

8. Brown, A.C. World-class sediment-hosted stratiform copper deposits: Characteristics, genetic concepts and metallotects. Aust. J. Earth Sci. 1997, 44, 317-328. [CrossRef]

9. Hitzman, M.W.; Kirkham, R.; Broughton, D.; Thorson, J.; Selley, D. The sediment-hosted stratiform copper ore system. Econ. Geol. 100th Anniv. Vol. 2005, 609-642.

10. Cox, D.P.; Lindsey, D.A.; Singer, D.A.; Moring, B.C.; Diggles, M.F. Sediment-Hosted Copper Deposits of the World: Deposit Models and Database; Open-File Report 03-107, Version 1.3, 2003, revised 2007; U.S. Geological Survey: Reston, VA, USA, 2003; pp. 1-53.

11. Taylor, C.D.; Causey, J.D.; Denning, P.D.; Hammarstrom, J.M.; Hayes, T.S.; Horton, J.D.; Kirschbaum, M.J.; Parks, H.L.; Wilson, A.B.; Wintzer, N.E.; et al. Descriptive Models, Grade-Tonnage Relations, and Databases for the Assessment of Sediment-Hosted Copper Deposits-With Emphasis on Deposits in the Central African Copperbelt, Democratic Republic of the Congo and Zambia; U.S. Geological Survey Scientific Investigations Report 2010-5090-J; U.S. Geological Survey: Reston, VA, USA, 2013; pp. 1-154.

12. Wyżykowski, J. Exploration for copper ores on the Fore-Sudetic area. Prz. Geol. 1958, 6, 17-22.

13. Rydzewski, A. Petrography of the copper-bearing Zechstein shales in the Fore-Sudetic Monocline (Lower Silesia). Biul. Inst. Geol. 1969, 217, 113-167.

14. Rydzewski, A. Oxidated facies of the copper-bearing Zechstein shale in the Fore-Sudetic monocline. Prz. Geol. 1978, 26, 102-108.

15. Oszczepalski, S.; Rydzewski, A. Copperbearing Permian rocks in areas adjoining the Lubin-Sieroszowice dposit. Prz. Geol. 1983, 31, 437-444.

16. Rentzsch, J.; Knitzschke, G. Die Erzmineralparagenesen des Kupferschiefer und ihre regionale Verbreitung. Freib. Forsch H 1968, C231, 189-211.

17. Oszczepalski, S.; Rydzewski, A. The Kupferschiefer mineralization in Poland. Zbl. Geol. Paläont. Teil I 1991, 4, 975-999.

18. Oszczepalski, S.; Rydzewski, A. Metallogenic Atlas of the Zechstein Copper-Bearing Series in Poland; Państwowy Instytut Geologiczny: Warszawa, Poland, 1997.

19. Wyżykowski, J. Zechstein copper-bearing formation in Poland. Prz. Geol. 1971, 19, 117-122.

20. Oszczepalski, S.; Rydzewski, A. Copper ores. In The Balance of Mineral Prospective Resources in Poland as of 31.XII.1990; Bąk, B., Przeniosło, S., Eds.; Państwowy Instytut Geologiczny: Warszawa, Poland, 1993; pp. 98-116. (In Polish)

21. Oszczepalski, S.; Speczik, S. Copper and silver ores. In The Balance of Mineral Prospective Resources in Poland as of 31.12.2009; Wołkowicz, S., Smakowski, T., Speczik, S., Eds.; Polish Geological Institute: Warsaw, Poland, 2011; pp. 76-93. (In Polish)

22. Oszczepalski, S.; Chmielewski, A. Predicted metallic resources in Poland: Presented on the prospective maps at scale 1:200 000-Copper, silver, gold, platinum and palladium in the Kupferschiefer ore series. Prz. Geol. 2015, 63, 534-545.

23. Mikulski, S.Z.; Oszczepalski, S.; Czapowski, G.; Gąsiewicz, A.; Sadłowska, K.; Markowiak, M.; Sztromwasser, E.; Bukowski, K.; Giełżecka-Mądry, D.; Mądry, S.; et al. The prospective areas and resources of metal ores and chemical raw materials in Poland on the maps at a scale of 1:200,000 with their resource assessment in relation to environmental and spatial conflicts. Prz. Geol. 2016, 64, 657-670.

24. Oszczepalski, S.; Speczik, S.; Małecka, K.; Chmielewski, A. Prospective copper resources in Poland. Miner. Res. Manag. 2016, 32, 5-30. [CrossRef]

25. Malon, A.; Tymiński, M.; Mikulski, S.Z.; Oszczepalski, S. Metal resources. In The Balance of Mineral Resources in Poland as of 31.12.2018; Szuflicki, M., Malon, A., Tymiński, M., Eds.; Państwowy Instytut Geologiczny: Warszawa, Poland, 2018; pp. 51-68. (In Polish)

26. Galos, K.; Nieć, M.; Radwanek-Bąk, B.; Smakowski, T.; Szamałek, K. The mineral security of Poland-barriers in meeting the state's needs for non-energy minerals. Biul. Państw. Inst. Geol. 2012, 452, 53-58.

27. Gospodarczyk, E. Research and prospecting works of copper-ore deposits in Poland during the last 30 years. Prz. Geol. 1976, 24, 181-185. 
28. Rydzewski, A. The history of the discovery of New Copper District. In Monografia KGHM Polska Miedź SA, Wydanie II; Piestrzyński, A., Banaszak, A., Zaleska-Kuczmierczyk, M., Eds.; Allexim sp. z o.o.: Wrocław, Poland, 1996; pp. 25-30. (In Polish)

29. Kaczmarek, W.; Rożek, R. History of geological surveys and exploration of Fore-Sudetic Monocline copper deposits after the World War II. Pr. Nauk. Inst. Gór. PWroc. 2006, 117, 113-121.

30. Oszczepalski, S. The 60th anniversary of the discovery of the Lubin-Sieroszowice copper ore deposit-New perspective. Prz. Geol. 2017, 65, 312-320.

31. Eisentraut, O. Der niederschlesische Zechstein und seine Kupferlagerstätte. Arch. Lagerst. Forsch. 1939, 71 , 1-116.

32. Roemer, F. Ergebnisse eines Tiefbohrloches bei Kraika, Bez. Breslau. Iber. Schles. Ges. Vaterl. Cultur. 1876, 54, 35-37.

33. Berger, F. 1932-Zur Geologie des tieferen Untergrundes der Umgebung von Breslau. Jber. Schles. Ges. Vaterl. Kultur. 1932, 105, 193-203.

34. Brockamp, B. Zum Bau des tieferen Untergrundes in Nordwest-Deutschland. Jb. Reichsamtf. Bodenf. 1941, 61, 157-185.

35. Zwierzycki, J. Potash salts north of Wrocław. Pr. Inst. Geol. 1951, 7, 257-295. (In Polish)

36. Preidl, M.; Dubiński, K.; Konstantynowicz, E.; Tomaszewski, J. Copper ore deposit of the Fore-Sudetic zone. In Monography of Polish Copper Industry; Konstantynowicz, E., Ed.; Wydawnictwa Geologiczne: Warszawa, Poland, 1971; Volume I, pp. 111-231. (In Polish)

37. Banaszak, A.; Leszczyński, R. History of development of the copper ore deposit base in the Fore-Sudetic Monocline. Biul. Państw. Inst. Geol. 2007, 423, 43-58.

38. Gospodarczyk, E. The copperbearing and perspectives for further search in basal Zechstein rocks in the Fore-Sudetic Monocline and Żary Pericline. Prz. Geol. 1978, 26, 97-102.

39. Oszczepalski, S. Kupferschiefer in southwestern Poland: Sedimentary environments, metal zoning, and ore controls. In Sediment-Hosted Stratiform Copper Deposits; Geological Association of Canada Special Paper 36; Boyle, R.W., Brown, A.C., Jowett, E.C., Kirkham, R.V., Eds.; Geological Association of Canada: Ottawa, ON, Canada, 1989; pp. 571-600.

40. Oszczepalski, S. Origin of the Kupferschiefer polymetallic mineralization in Poland. Miner. Depos. 1999, 34, 599-613. [CrossRef]

41. Zientek, M.L.; Oszczepalski, S.; Parks, H.L.; Bliss, J.D.; Borg, G.; Box, S.E.; Denning, P.D.; Hayes, T.S.; Spieth, V.; Taylor, C.D. Assessment of Undiscovered Copper Resources Associated with the Permian Kupferschiefer, Southern Permian Basin, Europe; U.S. Geological Survey Scientific Investigations Report 2010-5090-U; U.S. Geological Survey: Reston, VA, USA, 2015; pp. 1-94.

42. Speczik, S.; Oszczepalski, S.; Nowak, G.J.; Grotek, I.; Strengel-Martinez, M. Alteration of organic matter as a new exploration guide for Kupferschiefer-type $\mathrm{Cu}-\mathrm{Ag}$ and $\mathrm{Au}-\mathrm{Pt}-\mathrm{Pd}$ deposits. In Mineral Deposit Research: Meeting the Global Challenge, Proceedings of the Eighth Biennial SGA Meeting, Beijing, China, 18-21 August 2005; Mao, J., Bierlein, F.P., Eds.; Springer: Berlin/Heidelberg, Germany, 2005; Chapter 9-51; pp. 1065-1068.

43. Speczik, S.; Oszczepalski, S.; Nowak, G.; Karwasiecka, M. Kupferschiefer-A hunt for new reserves. Biul. Państw. Inst. Geol. 2007, 423, 173-188.

44. Speczik, S.; Oszczepalski, S.; Chmielewski, A. Exploration and mining perspective of the Kupferschiefer series in SW Poland: Digging deeper? In Mineral Deposit Research for a High-Tech World, Proceedings of the 12th Biennial SGA Meeting, Uppsala, Sweden, 12-15 August 2013; Jonsson, E., Ed.; A.A. Balkema: Rotterdam, The Netherlands, 2013; Volume 2, pp. 687-690.

45. Oszczepalski, S.; Speczik, S. Maturity assessment by Rock-Eval pyrolysis as an exploration tool, Kupferschiefer, Poland. In Smart Science for Exploration and Mining, Proceedings of the Tenth Biennial SGA Meeting, Townsville, Australia, 17-20 August 2009; Williams, P.J., Ed.; James Cook University: Queensland, QLD, Australia, 2009; Volume 2, pp. 734-736.

46. Krzemiński, P.; Speczik, S. Prognostic deposit of Cu-Ag ore in the Lubuskie voivodship (SW Polska). Zesz. Nauk. IGSMiE PAN 2013, 85, 231-240.

47. Speczik, S.; Oszczepalski, S.; Chmielewski, A. Future of copper exploration in Poland. In Mineral Resources in a Sustainable World, Proceedings of the 13th SGA Biennial Meeting, Nancy, France, 24-27 August 2015; Andre-Mayer, A.S., Cathelineau, M., Muchez, P., Pirard, E., Sindern, S., Eds.; GeoRessources, Université de Lorraine: Nancy, France, 2015; Volume 5, pp. 2025-2028. 
48. Oszczepalski, S.; Chmielewski, A.; Speczik, S. Variability of ore mineralization in the north-west-trending extension of the Lubin-Sieroszowice deposit. Biul. Państw. Inst. Geol. 2017, 468, 109-141. [CrossRef]

49. Zieliński, K.; Speczik, S. Prospecting and documenting strategy for deep stratiform Cu-As ore deposits in Poland. Górn. Odkryw. 2019, 2, 56-62.

50. Zieliński, K.; Speczik, S.; Małecka, K. The strategy, instruments and results of deep copper and silver deposit exploration in the Fore-Sudetic Monocline. Zesz. Nauk. IGSMiE PAN 2017, 100, 313-328.

51. Kiersnowski, H.; Petecki, Z. Geology of the Zechstein basement of the Legnica-Głogów Copper District (LGOM) and its surroundings: A critical overview. Biul. Państw. Inst. Geol. 2017, 468, 175-198. [CrossRef]

52. Ziegler, P.A. Geological Atlas of Western and Central Europe, 2nd ed.; Shell Internationale Petroleum Mij. B.V. and Geological Society: London, UK, 1990.

53. Wagner, R. Stratigraphy and evolution of the Zechstein basin in the Polish Lowland. Pr. Państw. Inst. Geol. 1994, 156, 1-71.

54. Van Wees, J.-D.; Stephenson, R.A.; Ziegler, P.A.; Bayer, U.; McCann, T.; Dadlez, R.; Gaupp, R.; Narkiewicz, M.; Bitzer, F.; Scheck, M. On the origin of the Southern Permian Basin, Central Europe. Mar. Pet. Geol. 2000, 17, 43-59. [CrossRef]

55. Krzywiec, P.; Peryt, T.M.; Kiersnowski, H.; Pomianowski, P.; Czapowski, G.; Kwołek, K. Permo-Triassic evaporites of the Polish basin and their bearing on the tectonic evolution and hydrocarbon system, an overview. In Permo-Triassic Salt Provinces of Europe, North Africa and the Atlantic Margins; Soto, J.I., Flinch, J.F., Gabor, T., Eds.; Elsevier: Amsterdam, The Netherlands, 2017; pp. 243-261.

56. Peryt, T.M.; Durakiewicz, T.; Kotarba, M.J.; Oszczepalski, S.; Peryt, D. Carbon isotope stratigraphy of the basal Zechstein (Lopingian) strata in Northern Poland and its global correlation. Geol. Q. 2012, 56, 285-298. [CrossRef]

57. Speczik, S.; Püttmann, W. Origin of Kupferschiefer mineralization as suggested by coal petrology and organic geochemical studies. Acta Geol. Pol. 1987, 37, 167-187.

58. Sawłowicz, Z. Organic matter and its significance for the genesis of the copper-bearing shales (Kupferschiefer) from the Fore-Sudetic monocline (Poland). In Bitumens in Ore Deposits; Special Publication of the Society for Geology Applied to Mineral Deposits; Parnell, J., Ed.; Springer: Berlin, Germany, 1993; Volume 9, pp. 431-446.

59. Oszczepalski, S. Oxidative alteration of the Kupferschiefer in Poland: Oxide-sulfide parageneses and implications for ore-forming models. Geol. Q. 1994, 38, 651-672.

60. Speczik, S. Kupferschiefer mineralization in the light of organic geochemistry and coal petrology studies. Geol. Q. 1994, 38, 639-650.

61. Bechtel, A.; Gratzer, R.; Puttmann, W.; Oszczepalski, S. Variable alteration of organic matter in relation to metal zoning at the Rote Fäule front (Lubin-Sieroszowice mining district, SW Poland). Org. Geochem. 2001, 32, 377-395. [CrossRef]

62. Bechtel, A.; Gratzer, R.; Püttmann, W.; Oszczepalski, S. Geochemical characteristics across the oxic/anoxic interface (Rote Fäule front) within the Kupferschiefer of the Lubin-Sieroszowice mining district (SW Poland). Chem. Geol. 2002, 185, 9-31. [CrossRef]

63. Oszczepalski, S.; Nowak, G.J.; Bechtel, A.; Žák, K. Evidence of oxidation of the Kupferschiefer in the Lubin-Sieroszowice deposit: Implications for $\mathrm{Cu}-\mathrm{Ag}$ and Au-Pt-Pd mineralisation. Geol. Q. 2002, 46, 1-23.

64. Speczik, S. The Kupferschiefer mineralization of Central Europe: New aspects and major areas of future research. Ore Geol. Rev. 1995, 9, 411-426. [CrossRef]

65. Mayer, W.; Piestrzyński, A. Ore minerals from Lower Zechstein sediments at Rudna mine, Fore-Sudetic monocline, SW Poland. Pr. Mineral. 1985, 75, 1-72.

66. Vaughan, D.J.; Sweeney, M.; Friedrich, G.; Diedel, R.; Harańczyk, C. The Kupferschiefer: An overview with an appraisal of the different types of mineralization. Econ. Geol. 1989, 84, 1003-1027. [CrossRef]

67. Sawłowicz, Z. Primary copper sulfides from the Kupferschiefer, Poland. Miner. Depos. 1990, $25,262-271$. [CrossRef]

68. Pieczonka, J.; Piestrzyński, A.; Lenik, P.; Czerw, H. Distribution of ore minerals in the copper deposit, Fore-Sudetic Monocline, SW Poland. Biul. Państw. Inst. Geol. 2007, 423, 95-108.

69. Pieczonka, J. Factors Controlling Distribution of Ore Minerals within Copper Deposit, Fore-Sudetic Monocline, SW Poland; Wydawnictwa AGH: Kraków, Poland, 2011; pp. 1-195.

70. Kucha, H. Geochemistry of the Kupferschiefer, Poland. Geol. Rundsch. 1990, 79, 387-399. [CrossRef] 
71. Piestrzyński, A.; Salamon, W. Perspectives of silver bearing capacity of the eastern part of copper deposits in the Fore-Sudetic Monocline. Gospod. Surowcami Miner. 1986, 2, 469-481.

72. Piestrzyński, A.; Tylka, W. Silver amalgams from the Sieroszowice copper mine, Lubin-Sieroszowice district, SW Poland. Mineral. Pol. 1992, 23, 17-25.

73. Kozub-Budzyń, G.A.; Piestrzyński, A. Geochemical characteristic of Ag-bearing minerals occurring in copper ore deposits at the Fore-Sudetic Monocline. Biul. Państw. Inst. Geol. 2017, 468, 49-60. [CrossRef]

74. Oszczepalski, S.; Rydzewski, A. Zechstein polymetallic mineralization on the Żary Pericline. Pr. Państw. Inst. Geol. 1995, 151, 21-34.

75. Oszczepalski, S.; Chmielewski, A. Mineralization of the Zechstein Lower Anhydrite in the Fore-Sudetic Monocline. Biul. Państw. Inst. Geol. 2018, 472, 135-154. [CrossRef]

76. Piestrzyński, A.; Pieczonka, J.; Speczik, S.; Oszczepalski, S.; Banaszak, A. Noble metals from the Kupferschiefer-type deposits, Lubin-Sieroszowice, SW Poland. In Mineral Deposits: Resources and Exploration-Where do They Meet, Proceedings of the Fourth Biennial SGA Meeting, Turku, Finland, 11-13 August 1997; Papunen, H., Ed.; A.A. Balkema: Rotterdam, The Netherlands, 1997; pp. 563-566.

77. Pieczonka, J.; Piestrzyński, A.; Mucha, J.; Głuszek, A.; Kotarba, M.; Więcław, D. The red-bed-type precious metal deposit in the Sieroszowice-Polkowice copper mining district, SW Poland. Ann. Soc. Geol. Pol. 2008, 78, 151-280.

78. Kucha, H.; Przybyłowicz, W. Noble metals in organic matter and clay-organic matrices, Kupferschiefer, Poland. Econ. Geol. 1999, 94, 1137-1162. [CrossRef]

79. Oszczepalski, S.; Rydzewski, A.; Speczik, S. Rote Fäule-related Au-Pt-Pd mineralization in SW Poland: New data. In Mineral Deposits: Processes to Processing, Proceedings of the Fifth Biennial SGA Meeting, London, UK, 22-25 August 1999; Stanley, C., Ed.; A.A. Balkema: Rotterdam, The Netherlands, 1999; pp. 1423-1426.

80. Piestrzyński, A.; Sawłowicz, Z. Exploration for Au and PGE in the Polish Zechstein copper deposits (Kupferschiefer). J. Geochem. Explor. 1999, 66, 17-25. [CrossRef]

81. Oszczepalski, S. Au-Pt-Pd mineralization in the Zechstein Kupferschiefer series on the reserved areas for copper mining. Biul. Państw. Inst. Geol. 2007, 423, 109-124.

82. Chmielewski, A. Variability of ore mineralization in the lowermost Zechstein across the redox interface in the western part of the Polkowice deposit. Biul. Państw. Inst. Geol. 2011, 444, 33-45.

83. Chmielewski, A. Characteristic of relict mineralization in the northern part of Radwanice copper field (SW part of Lubin-Sieroszowice deposit). Biul. Państw. Inst. Geol. 2014, 458, 1-24. [CrossRef]

84. Chmielewski, A.; Oszczepalski, S.; Speczik, S. Relict mineralization in the transition zone, Kupferschiefer series of SW Poland. In Mineral Resources in a Sustainable World, Proceedings of the 13th SGA Biennial Meeting, Nancy, France, 24-27 August 2015; Andre-Mayer, A.S., Cathelineau, M., Muchez, P., Pirard, E., Sindern, S., Eds.; GeoRessources, Université de Lorraine: Nancy, France, 2015; Volume 5, pp. 1897-1900.

85. Kucha, H.; Pawlikowski, M. Two-brine model of the genesis of strata-bound Zechstein deposits (Kupferschiefer type), Poland. Miner. Depos. 1986, 25, 262-271. [CrossRef]

86. Kucha, H. Geology, mineralogy and geochemistry of the Kupferschiefer, Poland. In Europe's Major Base Metal Deposits; Kelly, J.G., Andrew, C.J., Ashton, J.H., Boland, M.B., Earls, G., Fusciardi, L., Stanley, T.G., Eds.; Irish Association for Economic Geology: Dublin, Ireland, 2014; pp. 215-238.

87. Jowett, E.C. Genesis of Kupferschiefer Cu Ag deposits by convective flow of Rotliegendes brines during Triassic rifting. Econ. Geol. 1986, 81, 1823-1837. [CrossRef]

88. Jowett, E.C.; Pearce, G.W.; Rydzewski, A. A Mid-Triassic paleomagnetic age of the Kupferschiefer mineralization in Poland based on a revised apparent polar wander path for Europe and Russia. J. Geophys. Res. 1987, 92, 581-598. [CrossRef]

89. Jowett, E.C.; Rydzewski, A.; Jowett, R.J. The Kupferschiefer Cu-Ag ore deposits in Poland: A re-appraisal of the evidence of their origin and presentation of a new genetic model. Can. J. Earth Sci. 1987, 24, 2016-2037. [CrossRef]

90. Püttmann, W.; Hageman, H.W.; Merz, C.; Speczik, S. Influence of organic material on mineralization processes in the Permian Kupferschiefer Formation, Poland. Org. Geochem. 1988, 13, 357-363. [CrossRef]

91. Püttmann, W.; Merz, C.; Speczik, S. The secondary oxidation of organic material and its influence on Kupferschiefer mineralization of southwest Poland. Appl. Geochem. 1989, 4, 151-161. [CrossRef]

92. Püttmann, W.; Fermont, W.J.J.; Speczik, S. The possible role of organic matter in transport and accumulation of metals exemplified at the Permian Kupferschiefer formation. Ore Geol. Rev. 1991, 6, 563-579. [CrossRef] 
93. Cathles, L.M., III; Oszczepalski, S.; Jowett, E.C. Mass balance evaluation of the late diagenetic hypothesis for Kupferschiefer Cu mineralization in the Lubin basin of southwestern Poland. Econ. Geol. 1993, 88, 948-956. [CrossRef]

94. Nawrocki, J. Clay mineralogy, crystallinity, and K-Ar ages of illites within the Polish Zechstein Basin: Implications for the age of Kupferschiefer mineralization-A discussion. Econ. Geol. 2000, 95, 241-242. [CrossRef]

95. Bechtel, A.; Elliott, W.C.; Wampler, J.M.; Oszczepalski, S. Clay mineralogy, crystalinity and K-Ar ages of illites within the Polish Zechstein basin: Implications for the age of Kupferschiefer mineralization. Econ. Geol. 1999, 94, 261-272. [CrossRef]

96. Mikulski, S.Z.; Stein, H.J. Re-Os isotopic age of the Cu-Ag sulfide ore and its mineralogical and geochemical charakteristic from the Lubin-Polkowice mining area (SW Poland). Biul. Państw. Inst. Geol. 2017, 468, 79-96. [CrossRef]

97. Blundell, D.J.; Karnkowski, P.; Alderton, D.H.M.; Oszczepalski, S.; Kucha, H. Copper mineralization of the Polish Kupferschiefer: A proposed basement fault-fracture system of fluid flow. Econ. Geol. 2003, 98, 1487-1495. [CrossRef]

98. Wodzicki, A.; Piestrzyński, A. An ore genetic model for the Lubin-Sieroszowice mining district, Poland. Miner. Depos. 1994, 29, 30-43. [CrossRef]

99. Michalik, M.; Sawłowicz, Z. Multi-stage and long-term origin of the Kupferschiefer copper deposits in Poland. In Mineral Deposits at the Beginning of the 21st Century, Proceedings of the Joint Sixth Biennial SGA Meeting, Kraków, Poland, 26-29 August 2001; Piestrzyński, A., Ed.; A.A. Balkema: Rotterdam, The Netherlands, 2001; pp. 235-238.

100. Alderton, D.H.M.; Selby, D.; Kucha, H.; Blundell, D.J. A multistage origin for Kupferschiefer mineralization. Ore Geol. Rev. 2016, 79, 535-543. [CrossRef]

101. Borg, G.; Piestrzyński, A.; Bachmann, G.H.; Püttmann, W.; Walther, S.; Fiedler, M. An overview of the European Kupferschiefer deposits. In Geology and Genesis of Major Copper Deposits and Districts of the World-A Tribute to Richard H. Sillitoe; Special Publications of the Society of Economic Geologists; Hedenquist, J.W., Harris, M., Camus, F., Eds.; Society of Economic Geologists: Littleton, CO, USA, 2012; Volume 16, pp. 455-486.

102. Symons, D.T.A.; Kawasaki, K.; Walther, S.; Borg, G. Paleomagnetism of the Cu-Zn-Pb-bearing Kupferschiefer black shale (Upper Permian) at Sangerhausen, Germany. Miner. Depos. 2011, 46, 137-152. [CrossRef]

103. Speczik, S.; Skowronek, C.; Friedrich, G.; Diedel, R.; Schumacher, C.; Schmidt, F.P. The environment of generation of some base metal Zechstein occurrences in central Europe. Acta Geol. Pol. 1986, 36, 1-35.

104. Kubiak, J.; Banaś, M.; Piestrzyński, A.; Rydzewski, A.; Nieć, M. Grodziec Syncline. In Monografia KGHM Polska Miedź SA, Wydanie II; Piestrzyński, A., Banaszak, A., Zaleska-Kuczmierczyk, M., Eds.; Allexim sp. z o.o.: Wrocław, Poland, 1996; pp. 277-286. (In Polish)

105. Krzemiński, P. Textures and geochemistry of silver minerals from Kupferschiefer in the western part of Fore-Sudetic Monocline. In Mineral Resources in a Sustainable World, Proceedings of the 13th SGA Biennial Meeting, Nancy, France, 24-27 August 2015; Andre-Mayer, A.S., Cathelineau, M., Muchez, P., Pirard, E., Sindern, S., Eds.; GeoRessources, Université de Lorraine: Nancy, France, 2015; Volume 5, pp. 1945-1948.

106. Chmielewski, A. Structural and textural characteristics of Lower Zechstein secondary mineralization in the southwestern area of the Żary Pericline. Biul. Państw. Inst. Geol. 2012, 448, 333-344.

107. Speczik, S.; Dziewińska, L.; Pepel, A.; Jóźwiak, W. Reprocessing of archival geophysical data as useful instrument in $\mathrm{Cu}-\mathrm{Ag}$ deposit prospection of Fore-Sudetic Monocline. Biul. Państw. Inst. Geol. 2012, 452, 257-286.

108. Goodell, T.; Jorgensen, M.; Bohnet, E. Technical Report of the Miedzi Copper Project, Poland; RungePincockMinarco: Lakewood, CO, USA, 2017; Unpublished work.

109. Bohnet, E.; Goodell, T.; Jorgensen, M. Technical Report on Miedzi Copper's Sulmierzyce Project, Poland; RungePincockMinarco: Lakewood, CO, USA, 2017; Unpublished work.

110. Zieliński, K.; Wierchowiec, J. The equivalent copper producibility of polymetallic $\mathrm{Cu}, \mathrm{Ag}, \mathrm{Zn}, \mathrm{Pb}$ mineralisation in the Fore-Sudetic Monocline as illustrated by the Sulmierzyce-Odolanów prospective area. Zesz. Nauk. IGSMiE PAN 2018, 106, 257-274.

111. Addison, R.; Bohnet, E.; Haptonstall, J. Conceptual Mine Planning for Underground Extraction of Polish Kupferschiefer Copper Deposits; Pincock, Allen \& Holt: Lakewood, CO, USA, 2012; Unpublished work.

112. Brackebusch, F.W. Basics of paste backfill systems. Int. J. Rock Mech. Min. Sci. Geomech. Abstr. 1995, 32, 122A. 
113. Speczik, S. Chance or illusion? The case of deep copper and silver mines in Poland. Zesz. Nauk. IGSMiE PAN 2015, 91, 179-192.

114. Zieliński, K.; Speczik, S. Deep copper and silver deposits-A chance for Polish metal mining industry. Biul. Państw. Inst. Geol. 2017, 468, 153-164. [CrossRef]

115. McPherson, M. Refrigeration plant and mine air conditioning systems. In Subsurface Ventilation and Environmental Engineering; McPherson, M., Ed.; Springer Science \& Business Media: Dordrecht, The Netherlands, 1993; pp. 651-738.

116. Bellas, I.; Tassou, S.A. Present and future applications of ice slurries. Int. J. Refrig. 2005, 28, 115-121. [CrossRef]

117. Humphreys, D. Mining productivity and the fourth industrial revolution. Miner. Econ. 2019, 1-11. [CrossRef]

118. Bohnet, E.; Haptonstall, J.; Zeise, J. Second Expert Report by RPMGlobal USA Inc.-Miedzi Copper Corporation; RPMGlobal USA Inc.: Lakewood, CO, USA, 2018; Unpublished work.

(C) 2019 by the authors. Licensee MDPI, Basel, Switzerland. This article is an open access article distributed under the terms and conditions of the Creative Commons Attribution (CC BY) license (http://creativecommons.org/licenses/by/4.0/). 